Problems

(1)

Book Reviews

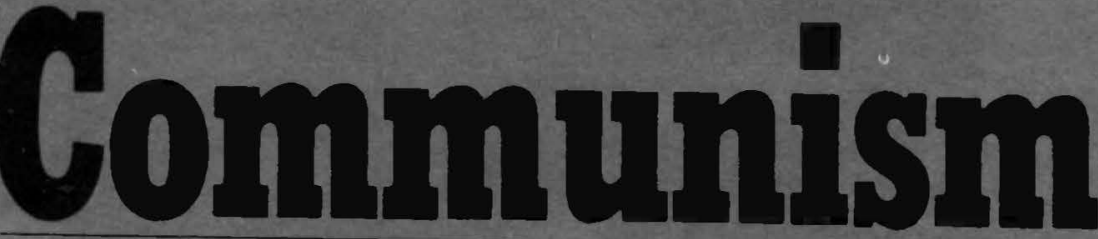

Robert Sharlet

Melvin Croan

Vladimir Tismaneanu

Barry M. Schutz

\title{
JANUARY-FEBRUARY 1986
}

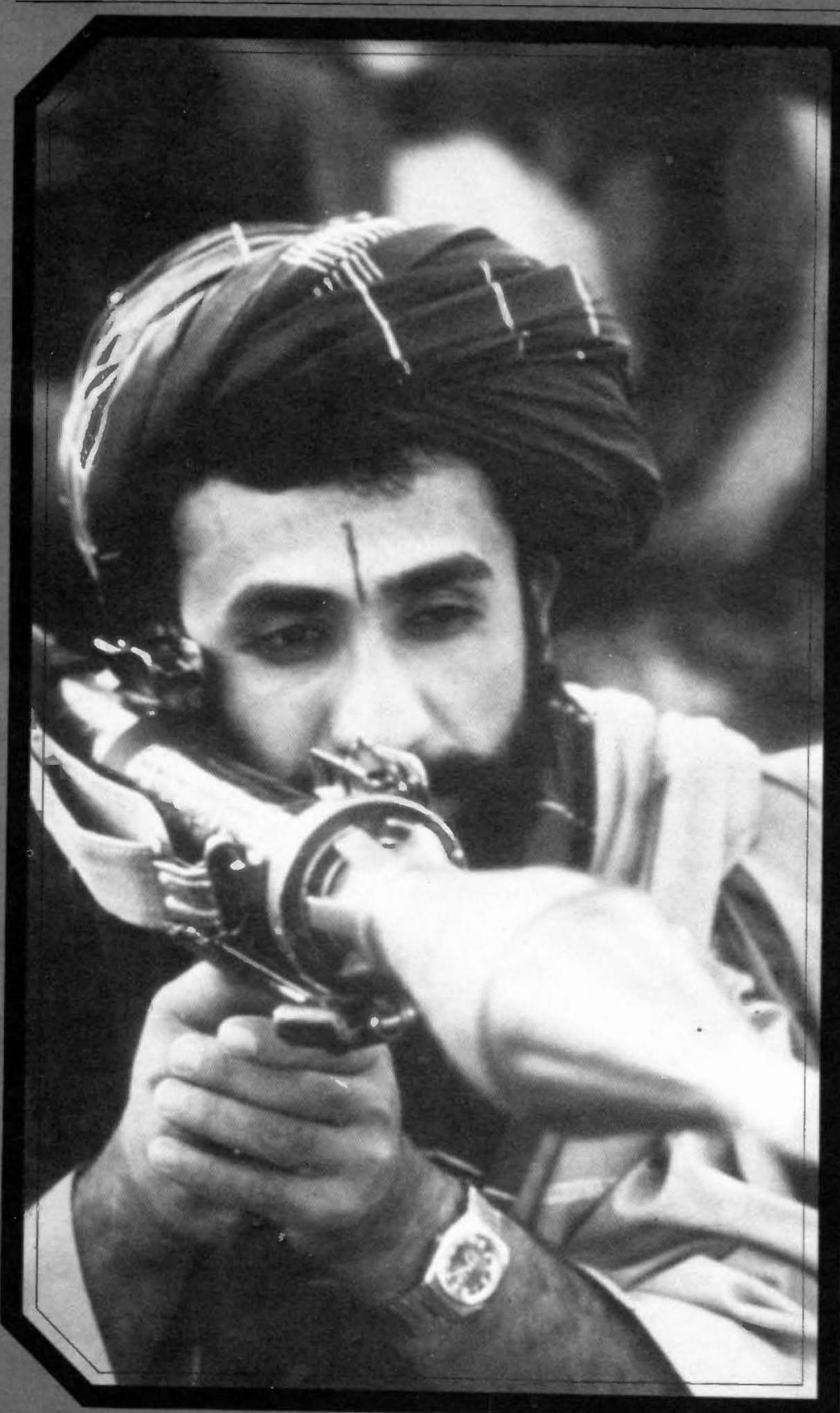

MOSCOW'S AFGHAN WAR

Zalmay Khalilzad

From Mao to Market Jan S. Prybyla

Gorbachëv and Eastern Europe Vladimir V. Kusin 


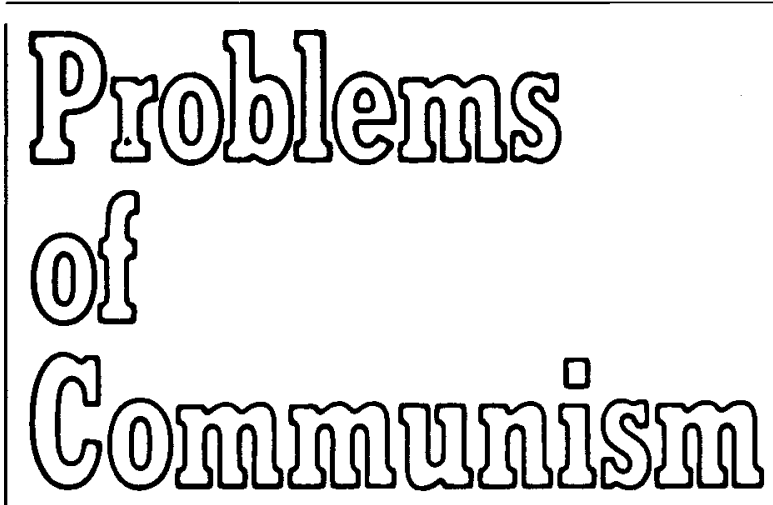

\section{JANUARY-FEBRUARY 1986 VOL XXXV}

Problems of Communism (ISSN 0032-941x) is a bimonthly publication providing analyses and significant information about the contemporary affairs of the Soviet Union, China, and comparable states and political movements. Views of contributors, as well as geographic boundaries and names, do not necessarily reflect the policies of the United States Government.

On all editorial matters, communications should be addressed to: The Editors, Problems of Communism, US Information Agency, United States of America, 301 4th Street SW, Washington, DC, 20547, USA. Telephone (202) 485-2230.

On subscriptions, communications should be addressed to: The Superintendent of Documents, US Government Printing Office, Washington, DC, 20402, USA preferably using the subscription form provided at the back of this issue. Outside the United States, please address inquiries to the Public Affairs Section, Embassy of the United States of America.

Copyright: Reproduction or republication of texts from Problems of Communism is permissible, and no claim of copyright is asserted. However, the Editors request that they be advised of reprint usage and that source credit be given both to the authors of individual articles and to Problems of Communism. Should textual items in the journal ever be subject to a claim of copyright, such claim will be clearly stated. Graphics and pictures that carry a credit line are not necessarily owned by Problems of Communism, and users bear responsibility for obtaining appropriate permissions.

An annual index for Problems of Communism appears in the November-December issue (No. 6) of each year except in the case of the first three volumes, which are covered in a combined index in the NovemberDecember issue (No. 6) of Vol. III. Material from the journal is also indexed in $A B C P O L S C l$. Bibliographie Internationale des Sciences Sociales (all sections), Current Contents, Economic Abstracts, Historical Abstracts, Index to US Government Periodicals, International Political Science Abstracts, Public Affairs Information Service, Social Sciences Citation Index Social Sciences Index, Strategic Studies Reference Guide, and United States Political Science Documents.
1

Moscow's Afghan War

by Zalmay Khalizad

21

China's Economic Experiment: From Mao to Market

by Jan S. Prybyla

39

Gorbachëv and Eastern Europe

by Vladimir V. Kusin

BOOKS

54

Politics of Soviet Law

by Robert Sharlet

61

Last Stages of Leninism

by Melvin Croan

67

Limits of Critical Marxism

by Viadimir Tismaneanu

77

Soviet Designs on Africa

by Barry M. Schutz

84

Correspondence

Cover: An Afghan resistance fighter takes aim with an anti-tank weapon. Photo by Pascal Pugin, Imapress via Pictorial Parade.

EDITOR

Paul A. Smith, Jr.

MANAGING EDITOR

Wayne Hall

SENIOR TEXT EDITOR Sophia Sluzar

ASSOCIATE EDITOR

Richard Snyder

\section{CONTRIBUTING EDITOR} Maria Pryshlak

DESIGNER

Gary Soderstrom

PRODUCTION COORDINATOR Sarah E. Mewborn

EDITORIAL ASSISTANT Kim Taylor 


\section{IN THIS ISSUE OF \\ Problems of Communism}

\section{Articles}

\section{Moscow's Afghan War \\ Zalmay Khalizad}

In the seventh year of its war in Atghanistan, the USSA is applying increasingly sophisticated military tactics to subdue the country. Moscow is pairing its military efforts with a domestic pacification program and an international campaign to gain legitimacy for a pro-Soviet communist government in Kabul For their part, the Afghan Mujahedin are contesting Kabul's legifimacy in international forums and holding their own against Soviet forces in Afghanistan

\section{China's Economic Experiment: From Mao to Market}

Jan S. Prybyla

Following a four-year period of adjustment that saw marked improvement in the quantitative performance of China's industry and agriculture, Chinese leaders in 1981 embarked on a new course of economic reform to help cure the economy's qualitative flis. Initially, experiments with free markets and privetization of labor and property were begun in the countryside. In 1985 , these experiments were extended to the urban industriat economy. Beljing stil faces the problem of reconciling the incompatibility between the market mechanism and central plan institutions.

\section{Gorbachev and Eastern Europe}

Vladimit v Kusin

Moscow's dealings with Eastern Europe since Mikhail Gorbachev's accession have been generally characterized by continuity. Policies of bloc integration and military cooperation have been pursued with little significant change beyond a modest increase in Sovel vigot. Gorbachevs steps to date have offered little prospect of improving economic performance, the Achilles' heel of the region

\section{Essay-reviews}

\section{Politics of Soviet Law}

Robert Sharlet

Although "socialist legality' is no longer 99 percent poitical, the Communist party of the Soviet Union continues to interfere in the everyday administration of justice - a point well illustrated by recent emigré Soviet jurists. The interplay between politics and law in the USSR raises the question as to what, if any positive role Soviet jurists can play in shaping the system's future. 


\section{Last Stages of Leninism}

Melvin Croan

The survival of the Soviet system depends on its ability to meet the challenge of change. To meet this challenge, the Sovet leadership needs to abahdon crucial tenets of Leninist ideology; but such a step would undermine the Soviet party-state's ctain to legitimacy.

\section{Limits of Critical Marxism}

Vladimir Tismaneanu

The potential contribution of Eastern Europe's critical Marxists is severely Iinited by thet unwilingness or inability to discard the fundamental Marxist categories that buthess the dictatorial Sovet-type regimes they so cogently criticize in their writlags, this contradiction is revealed in several books by or about the Budapest School and the philosophers that coalesced around the Yugoslav journal Praxis.

\section{Soviet Designs on Africa}

Barry M. Schutz

The Soviet Union stepped up its involvement in Atrica between 1975 snd 1979 . The hallmarks of This period were the USSR's Use of milltary surrogates and its enhanced ability to provide quick and massive military assistance, Despite mixed success, the Soviets continue to strve for their ultimate objective in Africa - political advantage over the West. 


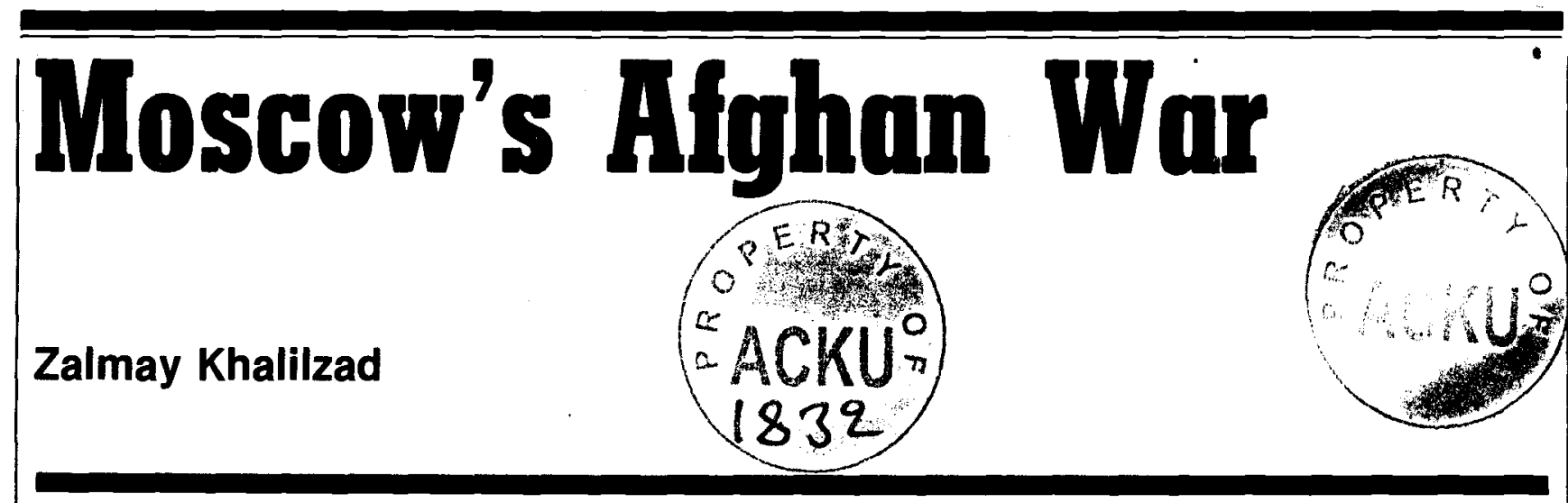

0

n December 27, 1985, Moscow's war in Afghanistan entered its seventh year. It has yet to progress according to Soviet expectations. The Soviet-installed regime of Babrak Karmal remains ineffective. The factionalism in the People's Democratic Party of Afghanistan (PDPA) remains fierce. But most important, despite a commitment of some 120,000 Soviet troops, the Soviet and Karmal forces have been unable to rout the anti-Soviet, anticommunist forces, the Mujahedin. And so the war goes on.

But this is not the story of a stalemate. Rather, it is a tale of changing Soviet tactics against continued partisan resistance, and of increasing competition between them for the support of the Afghan people at home and for public sentiment abroad. For its part, Moscow is escalating its military efforts and applying political pressure in the hope of undermining the Afghans' will to resist. The greater military effort is accompanied by a large-scale program of "Sovietization" designed to transform Afghan society along socialist lines. Moscow is also renewing its efforts to lessen support for the Mujahedin in states friendly to them, especially Pakistan and Iran. It has allowed the Kabul regime to engage in UN-sponsored indirect talks with Pakistan, in the hope that diplomacy will supplement its military efforts against the Mujahedin. The leaders of the Afghan resistance, for their part,

Zalmay Khalizad is Associate Professor in the Department of Political Science, and a member of the Institute of War and Feace Studies, Columbia University (New York). He is author of Security of Southwest Asia (1984), and coauthor of "The Government of God": Iran's Islamic Republic (1984). The author wishes to thank professors Zbigniew Brzezinski and Robert Jervis for comments on an earlier draft, and the Ford Foundation for a grant to study security issues in the Asian rimland. are trying to strengthen a recently formed alliance among seven major factions, bring about greater coordination of military operations in Afghanistan, and adopt new political strategies in international forums. The war in Afghanistan is thus as much a test of will and resolve as it is a clash of opposing forces.

The war has been immensely costly for the Afghan people. Some 4 million, or nearly one in every four of the pre-invasion population, have become refugees in Iran or Pakistan. According to The New York Times some 500,000 Afghans have lost their lives since the Soviet invasion.' It is also estimated that up to four million Afghans have become displaced within their own country since they have been moving to the cities or to the mountains from the countryside to escape from the fighting. ${ }^{2}$ In some parts of Afghanistan famine and malnutrition are common. ${ }^{3}$

Yet, the Soviet Union has also had to pay a higher price for its involvement than Soviet leaders had probably anticipated. Although exact figures are difficult to come by, the estimates are that between 10,000 and 40,000 Soviet soldier's already have lost their lives in Afghanistan. ${ }^{4}$ Hundreds of planes, helicopters, tanks, and armored vehicles have been destroyed. ${ }^{5}$ Large facilities for accommodating Soviet forces in Afghanistan had to be constructed and some of them have had to be rebuilt or repaired after being attacked by the resistance groups. The direct costs of the six years of war have been estimated at 18 to 36 billion

'The New York Times, Dec. 10, 1985.

${ }^{2}$ See Statement of G. Hekmatyar to the UN, New York, October 1985.

${ }^{3}$ For a discussion of humanitarian needs, see the statement by Gerald $B$. Helmand and Richard Schifter submitted to the Commission on Security and Cooperation in Europe, US Congress, Dec. 4, 1985.

4 Estimates of the number of Soviet fatalities vary a great deal. The Mujahedin estimate Soviet losses at 50,000 dead by the end of 1985 . The US government estimates that some 10,000 Soviets have died in Afghanistan over the past six years. See The Washington Post, Dec. 2, 1985.

${ }^{5}$ According to US government estimates, the Soviets have lost 700 aircraft in Afghanistan. Ibid 
US dollars, not an insignificant amount for an economy that already suffers from serious shortcomings. ${ }^{6}$ The Soviets also have had to assume some of the burden of the Afghan economy which has been severely disrupted by the war. Moscow even has had to pay some of Afghanistan's foreign debt.

Afghanistan continues to be a political vulnerability for the Kremlin. To the Soviets' dismay, they are widely seen as being colonialists. The UN General Assembly has called for the departure of "foreign troops" from Afghanistan since 1980 with larger majorities each year. The image of the Red Army has been tarnished by reports of the Soviet soldiers' drug abuse and defections. Soviet human rights abuses, detailed for example in the 1985 UN-sponsored report by Felix Ermacora, ${ }^{7}$ the activities around the world of groups supportive of the Mujahedin, and the continuing effectiveness of the principal resistance groups in Afghanistan continue to embarrass Moscow.

In spite of these costs, neither side appears willing to give up the fight or to accept a "political settlement" that does not meet its chief goals. The basic Soviet $\mathrm{goal}$ is to assure the continued existence of a friendly communist regime in Afghanistan. The Mujahedin refuse to accept such a regime. Thus, both sides are preparing for a protracted struggle, and each is hoping that time will be on its side.

This article will review the Soviet conduct of the war, as well as Moscow's pacification strategy. It will also look at the resistance forces and their efforts to oppose the Soviet Union both militarily and politically. To gain a better understanding of Soviet involvement in Afghanistan, it is instructive to look at Soviet military tactics as they have evolved since the invasion.

\section{Soviet Military Tactics}

The Soviets have yet to devise a military strategy which would let them exercise real control over Afghanistan in short order. Their inability to do so has made them change their military tactics repeatedly and increase the number of their troops.

The Soviet invasion of Afghanistan began in

- For economic costs of the war, see Joseph J. Collins, "The Soviet Afghan War," in Robert E. Harkavy and Stephanie G. Neuman, Eds., The Lessons of Recent Wars in the Third World, Vol. 1, Lexington, MA, DC Heath, 1985, p. 197; also Nake Kamrany and Leon Poullada, The Potential of Afghanistan's Society and Institutions to Resist Soviet Penetration and Domination, Los Angeles, Modelling Research Group, 1985. The authors assert the economic costs could be US $\$ 12$ billion annually.

7 The Economic and Social Council of the United Nations, Situation of Human Rights in Atghanistan (New York), A140-843, Nov. 5, 1985. earnest on December 24, 1979 when Soviet airborne troops began to land at Kabul. Within three days, some 5,000 troops had been airlifted to the Afghan capital. With these forces the Soviets overthrew the communist government headed by Hafizullah Amin, disarmed Afghan soldiers in Kabul, and seized important facilities, such as the radio station. ${ }^{8}$ As the airborne troops were taking over the Afghan capital, two Soviet motorized rifle divisions crossed the Amu Darya (Oxus River) from Central Asia. More forces followed. By early January 1980, the number of Soviet soldiers had reached 85,000 .

The Soviets divided the country into seven military regions. The 201st Motorized Rifle Division, located at Konduz and Fayzabad, had primary responsibility for the security of the northeast. The 16th Motorized Rifle Division, based in Mazar-e-Sharif, was responsible for the security of Balkh province and surrounding areas. The 275th Division, operating out of Jalalabad, was assigned the East-Central region. The 105th Airborne Division and the 360th Motorized Rifle Division were made responsible for the security of Kabul and the surrounding areas. The 54th Division and the 68th Division were responsible for Herat and western Afghanistan. The 357th Motorized Rifle Division was stationed in Qandahar in the southeast. The Soviets also have air assault brigades in various locations. Some 30,000 soldiers based in Soviet Central Asia are held in reserve along the Afghan border for possible use in Afghanistan, especially northern Afghanistan. ${ }^{\circ}$

The number of Soviet troops stationed in Afghanistan was increased by about 10,000 soldiers annually in 1981, 1982, and 1984. There are indications that in 1985 the increase was between 5,000 and 10,000 . Thus, the total number of Soviet troops committed to Afghanistan is approximately $155,000-125,000$ inside Afghanistan and some 30,000 on the Afghan border. ${ }^{10}$

- As a KGB defector reported, the Soviets deployed in the vicinity of Kabul moved to eliminate Amin with speed and efficiency:

"Along the road, the column was stopped at an Afghan checkpoint. Afghan troops gathered around to find out what was happening. Suddenly the flaps of the front vehicle went up and the Afghans were machine-gunned to the ground. The column rolled on. When it reached the palace, the special troops attacked from three sides, while Colonel Bayerenov led the attack on the palace. The attack got off to a good start. It would have been even better had the leading armored vehicle not got caught up in the palace gates. Moscow wanted no Afghans left to tell the tale of what had happened in the palace. No prisoners were to be taken. Anybody leaving the building was to be shot on sight. Amin was found drinking in a bar on the lop floor of the palace. He was shot without question." Time (New York), Nov. 22, 1982.

- The New York Times, Oct. 9, 1980; David Isby, "Afghanistan, 1982: The War Continues," International Defense Review (Geneva), No. 11, 1982, and The International Institute for Strategic Studies, The Military Balance, 1984-1985, London, IISS, 1985.

10 US Government sources estimate that the total number of Soviet troops in Afghanistan was 120,000 in the fall of 1985. The Washington Post, Dec. 2, 1985. 


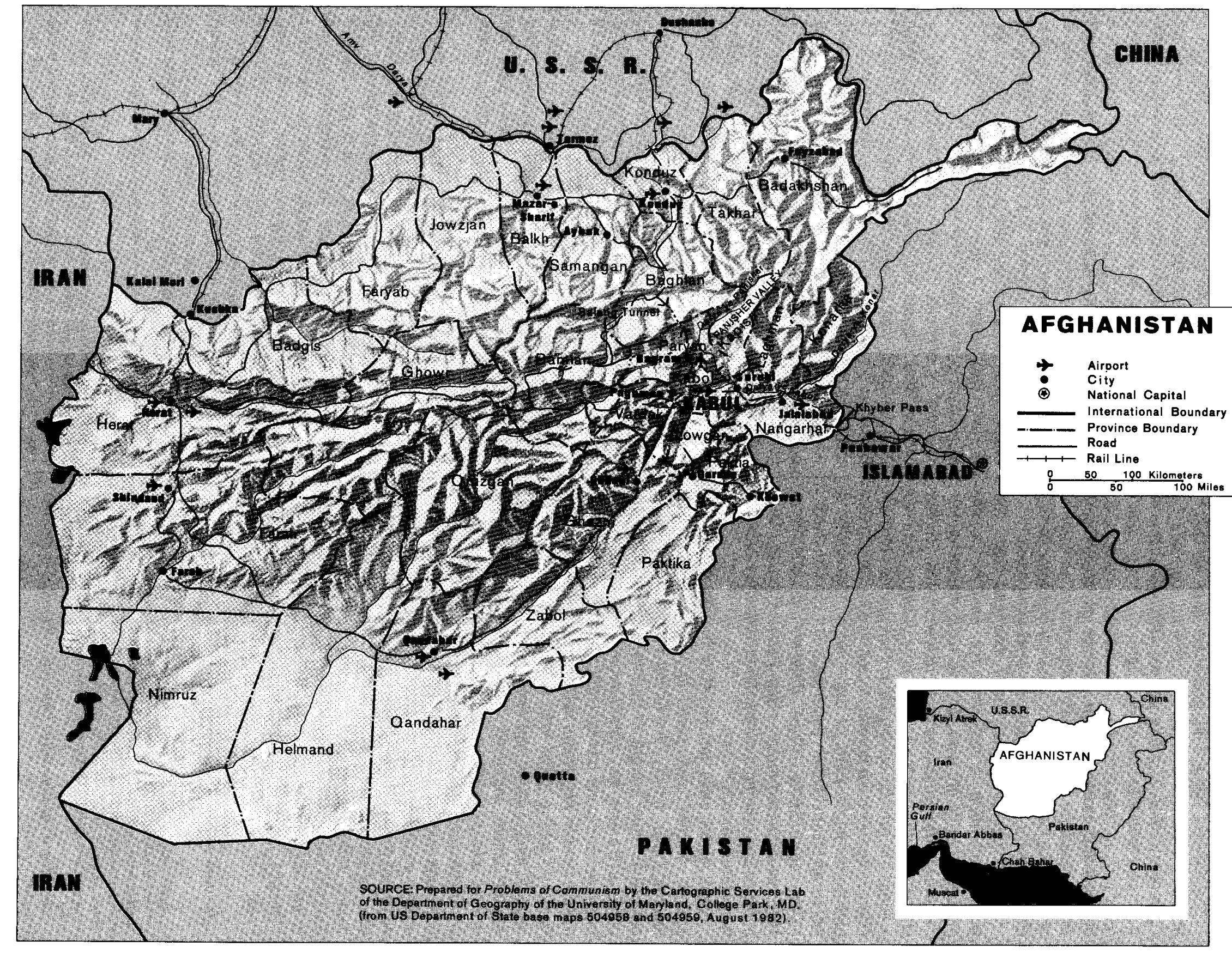


The Soviets have also upgraded their weapons. MiG-21 aircraft have been replaced by MiG-23 fighters and MiG-27 strike planes. Two squadrons of the sophisticated Su-25's fighters have been deployed in Afghanistan. The Soviets have also dramatically increased the number of $\mathrm{Mi}-24$ helicopter gunships and have introduced a large number of heavy-lift helicopters. The Soviet ground troops are also using much more sophisticated equipment. ${ }^{11}$

Soviet military tactics have changed over the years, indicating a trial-and-error search for approaches that might work. During 1980 , believing that the Mujahedin could easily be defeated, the Soviets employed large formations in an offensive strategy against the resistance forces, pursuing them to their strongholds. Intense fighting took place in the eastern and northeastern parts of the country, especially in Konar and Badakhshan provinces. But the Mujahedin - not surprisingly-used different tactics than Moscow expected them to use. Rather than standing in place and fighting a conventional war, they adopted hit-and-run tactics. ${ }^{12}$

Lack of success led Moscow to change its approach. Rather than pursuing the resistance and seeking quick victory, the Soviet forces went on the defensive. They sought to maintain control over the cities and towns, key communication points, military facilities, and main transportation arteries, thus leaving the countryside to the resistance. The shift, which occurred late in 1980, was influenced by two other factors. First, major uprisings occurred in several Afghan cities including Kabul, Herat, Jalalabad, Sorubi, and Aybak. ${ }^{13}$ Second, the resistance groups were complicating Soviet logistical problems and the normal economic functioning of the country by attacking the country's lines of communication. The Soviets were, as they continue to be, particularly concerned with threats against the Salang Tunnel on the road linking Kabul to the Soviet border in the north. The Panjshir partisans, led by Ahmed Shah Massud, who is by now the best-known of the Mujahedin commanders, were a continuous threat to the Salang Pass.

\footnotetext{
"Joseph J. Collins, "The Soviet-Afghan War," loc. cit., passim.

12 For a discussion of Soviet military efforts during 1980, see Zalmay Khalilzad, "Soviet Occupied Afghanistan," Problems of Communism (Washington, DC). November-December 1980; James Hansen, "Afghanistan: the Soviet Experience," National Defense (Arlington, VA), Vol. 66, 1982, pp. 20-22; Nearby Observer, "The Afghan-Soviet War: Stalemate or Evolution?" Middle East Journal (Washington, DC), Spring 1982

${ }^{13}$ Henry Bradsher, Afghanistan and the Soviet Union, Durham, NC, Duke University Press, 1983 , p. 208
}

The Soviets left the responsibility for pursuing the Mujahedin in the outlying areas largely to the Afghan regular forces under the control of the Karmal government. These forces, however, were much weakened after the Soviet invasion by the defections of between 30,000 and 40,000 soldiers to the Mujahedin. ${ }^{14}$ Moscow also began to rely more on small and mobile forces conducting search-and-destroy operations. According to many reports, including a number of documents released by the US government, the Soviets also began to use chemical weapons on a significant scale against the Mujahedin. ${ }^{15}$

Soviet operations in 1981 reflected the new approach. The biggest operations were carried out in Panjshir, because of concern over the security of Salang road, and in the Paghman area which is 16 miles northwest of Kabul. Between June and September both regions were subjected to major attacks by the Soviets. The Soviets responded to an uprising in the city of Qandahar with artillery bombardments.

The disappointing results of the 1981 operations prompted the Soviets to send a high-level delegation headed by First Deputy Defense Minister (now Defense Minister) Sergey Sokolov to Afghanistan at the end of the year. Apparently, Sokolov concluded that the number of Soviet forces was inadequate even for a defensive strategy and recommended that more forces be sent to Afghanistan. While their forces focused on holding the cities and keeping the lines of communication open, the Soviets encouraged Karmal to go on the offensive against the Mujahedin in the rural areas. Karmal exhorted his forces to take "the revolutionary struggle" to the provinces, districts, and villages.

Soviet efforts in 1982 again failed to bring major victories. Soviet forces bombed the Shomali region near Kabul because the Mujahedin had attacked the Bagram Air Base from that area. Moscow also applied substantial force against Herat in July after part of that city fell to the Mujahedin. The Soviets also carried out two offensives in the Panjshir valley to reduce the pressure against the Salang road (May and August). The May offensive was one of the biggest military operations since the invasion, involving some 12,000 to 15,000 soldiers. The Panjshir offensive was followed by a similar move once again against Paghman in June-July. ${ }^{16}$ By the end of July, the Kabul regime had

\footnotetext{
14 Ibid., p. 206.

is uS Department of State, Special Report (Washington, DC), Nos. 98 and 104, 1982

18 Edward Girardet, "How Stubborn Tribesmen Nibble Russians to Death," U.S. News and World Report (Washington, DC), July 12, 1982; and US Department of State, "Afghanistan: Three Years of Occupation," Speclal Report, No. 106, December 1982.
} 

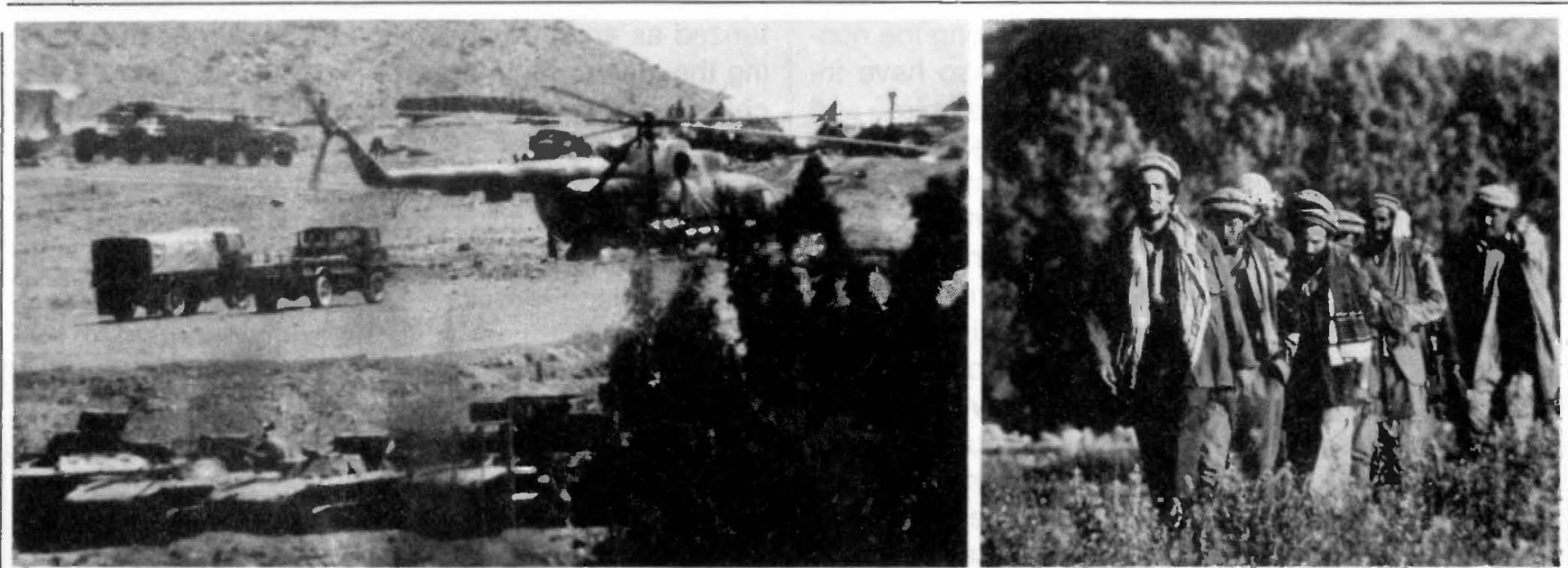

Vying for the Panjshir Valley: at left, a Soviet camp on the perimeter of the strategically important valley in August 1983; at right, resistance leader Ahmad Shah Massud (center), the "Lion of the Panjshir," leads a patrol.

-Nagákura/GAMMA-LIAISON.

declared the area free of Mujahedin. However, in October and November the Soviets carried out yet another offensive against the area. In both Paghman and Panjshir, the Soviet dilemma in 1982 was that when they moved into the area the Mujahedin retreated from the valley to the mountains and then carried out attacks against the Soviets and the Karmal troops at times of their choosing. In order to flush out the Mujahedin from caves where they had hidden, the Soviets continued to use chemical weapons-incapacitants, lethal chemicals, and perhaps even mycotoxin biological weapons. According to US government estimates, some 3,000 deaths resulted from Soviet use of these agents in 1981 and $1982 .{ }^{17}$

It was probably not until 1983 that the Soviet leaders realized that, short of a massive increase in the number of their forces, a quick military victory in Afghanistan was unlikely. Yet, the Soviets did not augment their forces in 1983. Moscow might have begun considering at that point the possibility that the negotiations on a settlement, initiated in 1982 under UN sponsorship, might bring about international acceptance of the Soviet-installed regime. Moscow may also have been reacting to growing international criticism of its conduct of the war, especially the use of chemical agents (which became considerably less frequent during 1983). ${ }^{18}$

From a military viewpoint, 1983 was a mixed year for the Soviets. Having failed to defeat the Mujahedin

17 US Department of State, Special Report, Nos. 98 and 104, 1982; also The Christian Science Monitor (Boston), Sept. 16, 1982.

'B William Branigan, "Afghanistan: Inside a Soviet War Zone," The Washington Post six-part series, October 1983. in Panjshir, the Soviets sought to divide the resistance parties by offering Massud a ceasefire to which he agreed. The ceasefire lasted until spring 1984, and caused some resentment against Massud both within his own group as well as among other resistance leaders. However, in several other areas the Soviets faced increased military pressure. During the summer, Kabul itself, its Bala Hissar barracks, and the Soviet military headquarters and embassy came un. der attack on a number of occasions. For several months, the Soviets lost control in parts of Herat, Mazar-e-Sharif, and Qandahar. To deal with these Mujahedin attacks, the Soviets bombed the western suburbs of Herat in April, causing heavy casualties. ${ }^{19}$

Soviet frustrations led to more modifications in tactics in 1984, including increased attacks on civilians, a greater reliance on Soviet troops, and the establishment of security outposts manned by Soviet troops. The Soviets apparently made a conscious decision to go after civilian targets directly in areas of strong resistance. Crops were burned, animals killed, and houses destroyed. At times, hundreds of civilians were killed. This led to the depopulation of some resistance strongholds - for example, Paghman, and parts of Panjshir, Logar, and Paktia. In some areas, the resistance units now have to bring along their own food supplies since the local population is no longer there to provide it. The object of this policy was to complicate the logistics of the resistance as well as to

10 Louis Dupree, "Afghanistan in 1983: And Still No Solution," Asian Survey (Berkeley, CA), February 1984; Sayed B. Majrooh, "Afghanistan 1983," Afghan Information Center, Monthly Bulletin (Peshawar), No. 32-33, November-December 1983; U.S. News and World Report, Aug. 1, 1983, p. 22 
undermine support for the resistance among the noncombatant population. Moscow might also have intended to increase the number of refugees in Iran and Pakistan in the hope of turning around the positive attitude toward the Mujahedin in both countries. ${ }^{20}$

The Soviets also began to employ a mix of large conventional forces and small special forces units in their operations. The special forces increasingly engaged in guerrilla-type operations against the $\mathrm{Mu}$ jahedin. Another innovation was the use of helicopter units for night-time attacks. The use of Soviet forces in challenging resistance control in the countryside increased, thus modifying an earlier tendency to leave that job to Karmal's forces. A large Soviet force was sent to Paktia province during April and May to relieve the besieged Khost military outpost, but failed to achieve this objective.

To make Kabul secure, most villages located within a five-mile radius (extended to 10 miles in 1985) were destroyed. Moscow also increased the number of military posts around the ring. This made large-scale infiltration of the city difficult. As a result, the resistance had to acquire rockets with a greater range so as to hit the Afghan capital. Moscow also increased the number of fixed military posts along important highways, for example, on the roads between Kabul and Konduz, and Kabul and Jalalabad.

The Soviets used a large number of their own forces to attack Panjshir in April. Heavy bombers based in the Soviet Union were used for high-altitude saturation bombing. The Soviets built five garrisons running the length of the Panjshir river valley. ${ }^{21}$ Most of the 40,000 civilians still there left the area and have not returned. However, the areas in the mountains remained in Massud's hands. Soviet efforts to kill or capture him also failed. This time, the operation against Panjshir was a bigger success than on previous occasions as it decreased the pressure on the Salang Pass and significantly increased Massud's difficulties. However, Soviet forces in the area were subjected to sustained attacks and also suffered many casualties.

The Panjshir operation was followed by similar attacks in Herat, Takhar, and Qandahar provinces. Again hundreds of civilians were killed because of indiscriminate bombing of residential areas in the cities of Herat and Qandahar. The resistance in turn increased its pressure against Soviet strongholds including the military base Khair Khana (near Kabul), and shelled the city of Kabul itself, causing frequent and serious disruptions in the supply of electricity and other services. ${ }^{22}$

The attacks in 1984 began a new phase in Soviet military policy in Afghanistan which can be charac- terized as an incremental escalation aimed at breaking the stalemate in the war. In 1985, the Soviets accelerated this trend. They carried out several major offensives against resistance strongholds-Herat was attacked twice, in April and October, Konar in June, Panjshir in July, and Paktia in September. ${ }^{23}$

Soviet military actions in 1985 also had two additional goals. First, the Soviets strengthened their efforts to cut off or limit the supply routes of the Mujahedin. Increased Soviet military activity near the Iranian and Pakistani borders was intended in part to serve this purpose. Lacking the manpower in Afghanistan to seal off the more than 1,500 miles of Pakistani border and the more than 400 mile-long border shared by Afghanistan with Iran, the Soviets have also relied on land mines and occasional special forces operations in the border areas. They are supplementing these efforts by seeking support among the Pashtun tribesmen in the Pakistani border area in the hope that these tribesmen would prevent the Mujahedin from crossing into Afghanistan. ${ }^{24}$ According to the $\mathrm{Mu}$ jahedin, however, Soviet efforts to close the supply routes have made access more difficult but by no means impossible.

By bringing the war closer to the Pakistani and Iranian borders, the Soviets are pursuing their second goal, namely, to induce Pakistan and Iran to cease supporting the Mujahedin. ${ }^{25}$ In late 1985 the Suviets carried out two major military offensives close to Pakistani territory in Konar and Paktia. As noted, they are also seeking friends among the tribes living along the Afghan border. Air and ground incursions into Iranian and Pakistani territory have increased. During 1985, there were over 200 such incursions against Pakistan. The Soviet press has been carrying increasingly strident criticisms of Iran's and Pakistan's support for the Mujahedin.

\section{The Sovietization Program}

The Soviets are pairing greater military efforts with a substantial political and economic program to mold

${ }^{20}$ John Keegan, "The Ordeal of Afghanistan," The Atlantic Monthly (Boston), November 1985. Kamrany and Poullada, op. cit., p. 121

21 "Panjshir-the Seventh Offensive," Central Asian Survey (Oxford), Incidental Papers Series, No. 1, 1985

zz US Department of State, "Afghanistan: Five Years of Occupation," Special Report, No. 120, December 1984.

${ }^{23}$ For reports on these attacks see the fortnightly bulletin, Afghan Realities, published by the Afghan Information and Documentation Center, Peshawar, Pakistan. Also see Monthly Bulletin and the reports in Afghanistan Forum (Washington, DC)

24 Author's interviews in Pakistan and New York, fall of 1985.

${ }^{25}$ The Musim (Islamabad), Oct. 11, 1985 
Afghan society in the Soviet image. ${ }^{26}$ This has produced a crippling dilemma. While the Sovietization program seeks to convert Afghans into loyal supporters of the communist regime, the massive use of force only increases the Afghans' hostility toward the Soviets and the communist regime that they support. Yet, to transform Afghanistan into a pacified Soviet satellite, the Soviets must first subdue the Afghan resistance militarily. Soviet cooptation efforts are unlikely to work as long as Moscow conducts what amounts to a genocidal war against the Afghans. Nevertheless, in the long term, Moscow's program might have some effect, especially if the war goes badly for the Mujahedin.

Moscow's program has many elements, including the expansion of existing Afghan coercive institutions and the creation of new ones under Soviet control. Moscow has sought to increase the size and competence of Kabul's armed forces in hopes of turning the war into a purely Afghan struggle and so gradually ending direct Soviet participation. (Here the Soviets have failed as Soviet direct involvement in the fighting against the Mujahedin has increased.) To augment the regime's forces, draft laws have been changed several times. Each change extended the length of service and lowered the draft age. At times, conscripts were made to remain in service even though they had completed their term. The regime also resorted to press gangs and street roundups of young men for military service. But these measures accompanied as they are by attacks against civilians and the misuse of Afghan soldiers and officers - have resulted in widespread defections and evasion of military service. Prior to the Soviet invasion the Afghan armed forces had numbered close to 100,000 ; at present they number between 40,000 and 50,000 men, many of whom are of questionable loyalty and some of whom directly or indirectly aid the Mujahedin. Afghan pilots have been known to drop their bombs in the desert rather than on the target area. On several occasions Afghan regular forces have sabotaged Soviet-controlled military facilities. One dramatic example of this occurred in May 1985 when some 20 aircraft were destroyed by Afghan officers at the Shindand military base. In another instance, officers with ties to the resistance flew two Mi-24 helicopters to Pakistan. ${ }^{27}$ In November 1985,- four army generals were arrested and reportedly executed for collaborating with the Mujahedin. ${ }^{28}$

\footnotetext{
${ }^{26}$ See Khalizad, "The Soviet Dilemma in Afghanistan," Current History (Philadelphia), October 1985, p. 334

${ }^{27}$ Afghan Realities, July 16,1985 provides details on these acts.
}

Struggles between adherents of the two factions of the People's Democratic Party of Afghanistan (PDPA) - the Parcham and Khalq - have particularly affected the armed forces. Although both factions were proSoviet, a split occurred in 1967 because of differences over organizational tactics (Khalqis wanted a Leninist-type party based on the working class, while Parchamis preferred a broad national democratic front) and personal rivalries that were compounded by social and ethnic differences (Khalqis are mainly rural Pashtuns while the Parchamis are mostly urbanized and Dari-speaking).

Prior to the Soviet takeover, Khalqi officers dominated the armed forces. However, since 1979 the number of Parchamis, whose leader Karmal was installed in power, has been increasing so fast in the armed forces that they might be now predominant. This is clearly resented by the Khalqis. Khalqi officers have been reluctant to follow the orders of Parchami officers. At times actual battles between the factions have taken place. For example, in June of 1983 fighting in the 25th Division between the two groups raged for three days. Parchamis often accuse Khalqi officers of cooperating with the Mujahedin. ${ }^{29}$ For the present, the Soviets appear to have little confidence in these Afghan forces and frequently behave as though they were expendable. Casualties among Kabul regime soldiers have been very high, perhaps three to five times higher than for Soviet soldiers. ${ }^{30}$

The state secret police, KHAD, has grown considerably since the invasion. This KGB-run organization is spreading its influence over the state and party apparatuses. Its status was enhanced officially in 1986 when it became the Ministry of Internal Security. It carries out surveillance over the government and the military, employing a mixture of brutal tactics and economic rewards to undermine popular support for the Mujahedin. It also seeks to infiltrate the resistance and probably has been responsible for the assassinations of several of its commanders. There are reports that KHAD may have more than 20,000 operatives among whom are a number of common thugs. The Soviets run a large training program for KHAD personnel. ${ }^{31}$ Although KHAD appears to be considerably more effective than the armed forces, it is embroiled

\footnotetext{
See Special Report, No. 135, December 1985, p. 7.

${ }^{29}$ Monthly Bulletin, April 1983. On the historical reasons for Parchami-Khalqi rivalry, see Anthony Arnold, Afghanistan's Two-Party Communism: Parcham and Khalq, Stanford, CA, Hoover Institution Press, 1983.

so The Washington Times, Jan. 13, 1986

"Henry Bradsher, "Afghanistan," The Washington Quarterly (Washington, DC), Summer 1984 , p. 51
} 
in conflicts with other institutions, notably the military. ${ }^{32}$

The Soviets have also had some successes with the militias whose formation they have promoted. The purpose of the militias is to decrease the military burden on the Soviet and Afghan armed forces and to win over critical local leaders. Local leaders are encouraged to form militias to keep the Mujahedin out of their areas. In return, they are allowed to keep their weapons and receive financial support and weapons from Kabul. The formation of militias has been fostered especially in the border areas to limit the infiltration and resupply of Mujahedin from neighboring states. However, militias in urban institutions, in factories and schools for example, have been created as well. The militias have at times been a significant problem for the resistance, even though some local leaders have sided with the Mujahedin after getting money and weapons from Kabul.

Another form of the Sovietization effort has been the expansion of the Afghan Communist party, the PDPA. Since the original communist coup of 1978 , when party membership stood at 5,000, the PDPA has expanded to more than 140,000 members according to Soviet and Kabul sources. ${ }^{33}$ Actual membership is probably half that number. Nevertheless, the party and its affiliated organizations have become a means for expanding the base of support for the regime. Under Soviet prodding, the Kabul regime has pressured government personnel, especially Afghan military officers, to join the party. A refusal to do so can bring loss of position and benefits. Many of those who have joined the party have done so for practical reasons - to obtain government jobs and contracts, admission to university, scholarships to study abroad, or merely to avoid problems with the occupying power.

These members would no doubt abandon the PDPA in large numbers if the collapse of the pro-Soviet regime became imminent or if the Soviet forces were about to leave. However, should the Soviets win the war or be perceived as doing so, the party would find many more recruits. Yet, the influx of new party members has done little to dilute the factional conflicts. The Khalqis, who lost much of their power to the Parchamis after the Soviet invasion, appear unreconciled to the present arrangements. Their hostility has been

32 Edward Girardet, "Russia's War in Afghanistan," Central Asian Survey, July 1983, pp. 94-95.

33 See report on Babrak Karmal's speech to the High Jirgah of Frontier Tribes Sept. 14, 1985, in Afghanistan Forum, November 1985, p. 5 a serious obstacle to Soviet military efforts because the Mujahedin are frequently informed of Soviet military plans when Afghan military forces are also involved in an operation.

Dealing with factionalism has absorbed a lot of energy on the part of the Soviets. A series of changes in party and state office-holders have been announced in 1985 by Kabul, in a probably futile effort to stop the factionalism. ${ }^{34}$ The Parchami Najibullah, former head of KHAD, has been named secretary of the PDPA Central Committee. He holds substantial responsibilities for several areas. It is possible that he is being positioned to replace Karmal-if and when the Soviets decide to do so. Najibullah's secretaryship is another indication of the growing influence of KHAD. The promotion of Ghulam Faruq Yaqubi, Najibullah's successor at KHAD, to full membership on the Central Committee points in the same direction.

Two Parchamis, Dastiqir Panjsheri and former Defense Minister Abdul Qader, have been dropped from the Politburo. Suleiman Laeq, also a Parchami, who is minister of tribes and nationalities, became a candidate member of the Politburo. Ismail Danesh, minister of mines and industries, who belongs to the Khalq faction, was dropped from the Politburo and sent into honorable political exile as Afghanistan's ambassador to Libya. Another Khalqi, Defense Minister Lt.-General Nazar Mohammad, has been promoted to candidate member of the Politburo. A Khalqi from the security apparatus to be promoted to full member of the Central Committee is Saifullah, commander of the Kabul police.

The Kabul regime has tried to build a facade of legitimacy for itself in 1985 through a series of public initiatives. On April 12, Kabul announced it would call a Loyah Jirga, the traditional grand assembly of Afghan tribal leaders. Historically, such assemblages were used by Afghan kings and by the republican government to gain acquiescence in a transfer of power or approval of a major new policy. In the 1980 Fundamental Principles of the Democratic Republic of Afghanistan, which serves as an interim constitution, the Loyah Jirga is defined as the "highest organ of state power." Yet, neither the Karmal regime nor the Amin government had convoked a Loyah Jirga, although regional jirgas were held. Reports of the event suggest that a high percentage of the 2,000 participants were regime functionaries, from the military

${ }^{34}$ On the personnel changes in late 1985, see Special Report, No. 135, December 1985 
or KHAD, or members of the PDPA or its front organizations. ${ }^{35}$

In August, local council elections were announced - the day before they were to begin. In Kabul, the "election" process was simple: a smattering of district residents were assembled at a meeting hall. Candidates were introduced only moments before the vote. Voting meant raising hands under the watchful eyes of KHAD agents; secret ballots were not used. The regime announced that 450,000 residents had participated, about 90 percent of eligible voters. ${ }^{36}$

In September, a High Tribal Jirga was convened for the Pathan and Baluch tribes whose territories span the borders with Pakistan and, in the case of the Baluch, also with Iran. This time, a somewhat higher proportion of the roughly 3,700 delegates actually were tribal representatives. ${ }^{37}$ Delegates reportedly received cash payments supplemented by arms for attending. The weapons were said to be for use in defending the frontier but were presumably also for use in tribal lands across the border, which would complicate the situation there for Pakistan.

A number of PDPA-dominated institutions have been established under the communist government. They are intended not only to make Afghanistan structurally similar to the USSR but also to facilitate the political indoctrination and mobilization of the population. This is especially true of institutions such as the Democratic Youth Organization, similar to the Soviet Komsomol, and its affiliate, the Pioneer organization, for children between ages 10 and 15. The Kabul regime and the Soviets are sparing no efforts to influence Afghan youths. Since the Soviet invasion, 25,000 to 40,000 Afghans have been sent to the Soviet Union to be educated. There are presently more students in the Soviet Union from Afghanistan than from any other country, with the possible exception of Vietnam. The adults who are educated in the Soviet Union are rewarded upon their return, generally with government positions. ${ }^{38}$

Increasingly, the Afghan students being selected for training in the Soviet Union are orphaned and quite young. They currently number between 5,000 and

\footnotetext{
${ }^{95} \mathrm{Ibid}$.

Ibid

${ }^{37}$ Ibid.

30 Der Spiegel (Hamburg), Nov. 4, 1985

so Ibid.

${ }^{40}$ The Christian Science Monitor, Dec. 30, 1985, pp. 7-8, and Jan. 6, 1986 ,

pp. 11-12; and Professor Batinshah Safi, "Russification of Education in Afghanistan,"

Peshawar, Afghanistan Education Committeo, mimeo., nd.

"IMF Directions of Trade 1985, Washington, DC, International Monetary Fund, 1985.

42 Edward Girardet, Afghanistan: The Soviet War, New York, St. Martin's Press, 1985, p. 155.
}

10,000 . Most are expected to spend as many as 10 years in the USSR. The emphasis on children and orphans is a newly visible element in Moscow's Sovietization program..$^{39}$ Afghan resistance commanders have reported capturing "child soldiers" between ages 8 and 15 who, they claim, have been trained in the Soviet Union to perform espionage work and carry out assassinations.

Yet the Soviet experience with Afghan students so far has not been entirely positive. The ongoing war obviously generates hostility toward Moscow even among them. Moreover, some face discrimination when in the Soviet Union. Nevertheless, even if only half of the students currently in the Soviet Union and Eastern Europe return to work in collusion with the Soviets, it undoubtedly could have a substantial impact on the future of Afghanistan. Moscow probably believes that Afghanistan will not be pacified until its Sovietization program succeeds in transforming traditional Afghan social patterns. No doubt, the Soviet investment in Afghanistan's young is intended to bring about such a transformation.

In Afghanistan itself, although a large number of the country's educational institutions have been disrupted or destroyed ( 50 percent according to Kabul government figures), those that remain under regime control are being restructured along Soviet lines. Russian is being made a required subject beginning with the fourth grade, while English, French, and German classes are being phased out. ${ }^{40}$ Many of the administrators and teachers in Afghan schools come from the Soviet Union or Eastern Europe. All cultural and educational cooperation agreements with Western nations have been terminated. The curriculum now includes courses on "sociology," which in fact teach communist ideology. The version of Afghanistan's history now being taught has been tailored to inculcate pro-Soviet and pro-regime attitudes.

Sovietization extends also to the economic sphere. The Soviet Union has not only increased its economic ties with Afghanistan since the invasion but has encouraged the Kabul regime to sever its ties to the West. Some 70 percent of Afghan trade is now with Soviet-bloc countries. ${ }^{41}$ The Soviets have encouraged the exploitation of Afghan natural resources. They have tripled their gas imports from Afghanistan, but pay less than the international price. Payments for gas are deducted from the growing "Afghan debt" to the Soviet Union. Afghan officials cannot tell how much gas is being exported to the USSR, since the meters are situated inside the Soviet Union and the Afghans do not have access to them. ${ }^{42}$ Infrastructural ties to the Soviet Union have been multiplied. Moscow 

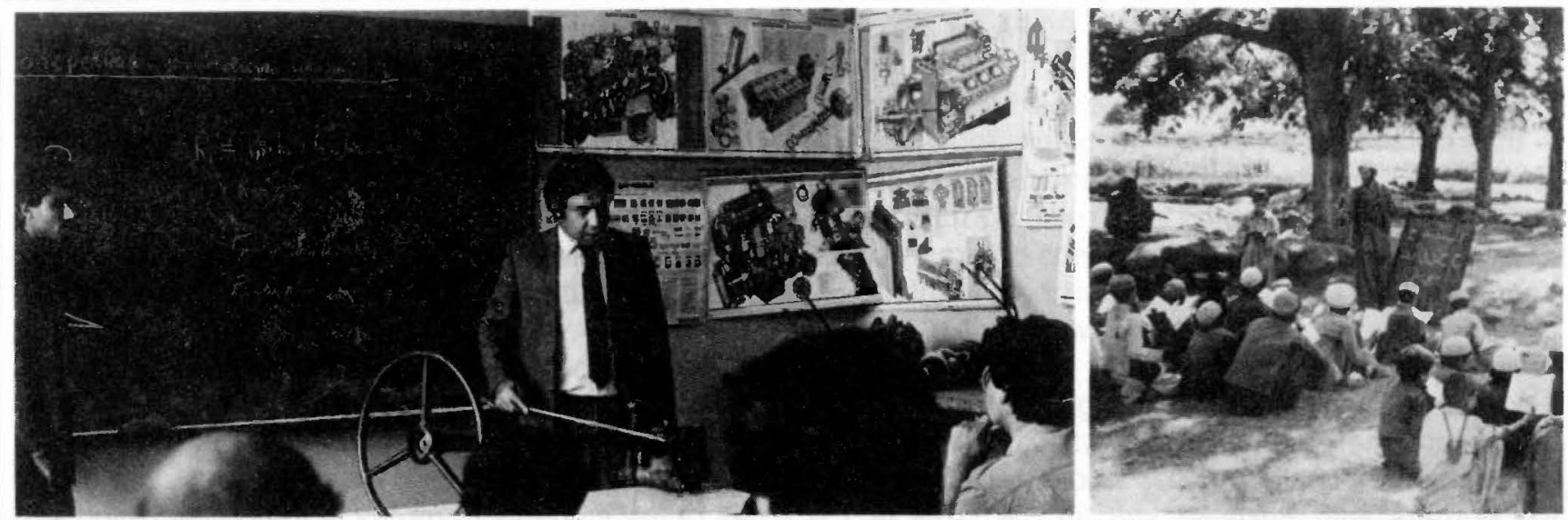

At left, Borak Abdulkadir, a graduate of Moscow's Highway Construction College, uses Russian to conduct a class in 1985 at the Polytechnical College in Kabul (built with Soviet technical assistance); at right, a school run by Afghan resistance forces in Konar province.

-TASS from SOVFOTO; Afghanistan Education Committee.

has even replaced the Afghan airline's planes acquired in the West with planes made in the Soviet Union. As in the political and military sphere, the Soviets are basically drafting the economic plans and programs to be followed by the Kabul regime. ${ }^{43}$

It is clearly Moscow's expectation that a combination of escalating military pressure and the ambitious Sovietization program will wear down the Afghan resistance over time. Although the results so far are mixed, it is still too early to expect the Soviets to decide on the failure or success of their current strategy. According to Deputy Foreign Minister Mikhail Kapitsa, Moscow expects its problem in Afghanistan to "be over" in five years. ${ }^{44}$ It is possible that if the Soviets fail to put down the resistance by 1990, they might conclude that their strategy has not worked. Soviet failure or success will be determined not only by the programs and actions of the Soviets and the Kabul regime but also by the performance of the Mujahedin and the policies of states concerned with the conflict in Afghanistan. Let us first review the efforts of the resistance movement.

\section{The Resistance}

The groups involved in the Afghan resistance are numerous, and their orientations and aspirations vary. They differ in ideology, in base of support, and in relative capability. All want the Soviet forces to leave, but

\footnotetext{
${ }^{43}$ Ibid.

"The Muslim, Oct. 11, 1985, p. 1

${ }^{45}$ Khalilzad, "Soviet Occupied Afghanistan," loc. cit., p. 38
}

each group has different additional goals. None wants the pre-invasion situation restored. All reject the communist regime that ruled for some 18 months before the Soviet invasion. Some want to bring about basic changes in the institutions under which they have lived, if need be by force. Others essentially want to restore the institutions overthrown by the communists. Thus, the war by the resistance against Soviet occupation is crossed by internal conflicts.

Those who want basic changes can be broadly described as Islamic "fundamentalists," even though there are significant differences within this category. ${ }^{45}$ As a rule, they advocate the establishment of a "new" political system, namely an Islamic Republic, which has not existed in Afghanistan before, and which does not exist in any Sunni Muslim country. The largest Afghan "fundamentalist" groups are Burhanuddin Rabbani's Jamiat-i-Islami; Gulbuddin Hekmatyar's Hezb-e-Islami; Yunus Khalis's Hezb-e-Islami Afghanistan; and Abdul Rasool Sayyaf's Islamic Alliance for the Liberation of Afghanistan.

Sayyaf is an eloquent orator in Arabic and won a prize for service to Islam in Saudi Arabia in 1984. He was born in about 1940, and received a bachelor's degree in religious studies from Kabul University and a master's degree from Al-Azhar in Cairo, where he probably joined the Muslim Brotherhood. He returned to Afghanistan in the late 1960's, and joined Hekmatyar's and Rabbani's Jawanani-Musulman, the Muslim Youth Organization, then active at Kabul University. In 1972, the leaders of this organization formed a political party, the Jamiat-i-Islami. Rabbani was elected president, Sayyaf, vice-president, and Hekmatyar became a member of the party's Council. 
Sayyaf was jailed by President Mohammad Daud in 1975 but was released in 1980 by Babrak Karmal's regime. Upon his release he went to Peshawar and joined the Mujahedin forces. He has often acted as spokesman for the fundamentalist parties. In domestic politics he favors a strict application of the Islamic law, the Sharia. In foreign policy, he advocates equidistance from the Soviet Union and the United States. ${ }^{46}$ Presently, he has close ties with Saudi Arabia.

Hekmatyar and Rabbani have also been influenced by Muslim Brotherhood beliefs. Hekmatyar, whose group is strong among the Pashtuns, was thought to be the best-organized political leader. In 1982, everyone agreed that his group was the largest. Today there is no such consensus. Hekmatyar's forces have been involved in most of the fights among the partisan groups. This factor perhaps has contributed to decreased support. ${ }^{47}$ Hezb-e-Islami has its origins in the late 1960's, when Hekmatyar and Rabbani were among the organizers of the Muslim Youth Organization before becoming involved in the Jamiat. At that time, Hekmatyar was studying engineering at Kabul University. In the mid-1970's, he fled to Pakistan, where he broke with Jamiat and established his own group. Allegedly, he received Pakistani support to work against President Daud. Like Sayyaf, Hekmatyar favors strict application of Islamic laws and has close ties with the Muslim Brotherhood in the Middle East. On international politics, his public position is that "both America and Russia are enemies of Islam."

Rabbani and Khalis comprise the moderate wing of the Afghan fundamentalist group. Khalis broke away from Hekmatyar in 1979. He is the oldest (born in 1919) of the Peshawar-based leaders. Both Khalis and Rabbani have moderated their views on domestic and foreign policy issues over time. They appear inclined to allow some political diversity in Afghanistan. At the international level, they were originally equally critical of the United States and the Soviet Union. Since 1983, however, they have been expressing more favorable views about the United States. ${ }^{49}$ Rabbani's base of support is largely among non-Pashtuns.

Another set of parties active against the Soviet forces and currently based in Pakistan can be classified as "traditionalist." They, too, declare that they want an Islamic government in Afghanistan. However, they would be satisfied if pre-1978 Afghan political institutions are restored. One such "traditionalist" party is Mahez-e Milli-ye Islami, headed by Ahmad Gailani; a second is Jabh-e Najat-e Milli, led by Siabghatullah Mojadeddi; a third is Mohammad Nabi's Haraket-e-Inqelab-ye-Islami.
The "traditionalists" represent the old elite. Gailani, for example, was a friend and adviser of former King Mohammad Zahir Khan. They desire a role for the former King (who is in Italy) and probably would be satisfied with a government headed by him. They have openly called for support from the West. At the domestic level, they have declared themselves in favor of a multi-party system but opposed to permitting the communists to form a legal party. On the whole, the traditionalists have not been as well organized as the fundamentalists. Allegations about the misuse of funds have been directed more frequently against these groups than against the fundamentalists.

While the Pakistan-based groups are the largest resistance organizations, there are other important groups. These include the Shiites in Central Afghanistan, who can be subdivided into those supported by Iran (NASR and Sepah) and those independent of Iran (Shura-ye Ettefaq, Harakat-i-Islami, and Mustazafin). ${ }^{50}$ There are also a number of groups independent of both the Shiite organizations and the Pakistan-based Sunni groups. In the Nooristan region of eastern Afghanistan, for example, there are the Free Resistance Front and the Free Government group.

Although these groups have had substantial success individually in opposing the Soviets, a lack of unity has prevented them from realizing fully their political and military potential. In fact, they have spent a significant part of their resources fighting each other. This has enabled the Soviets to avoid paying a higher price for their occupation and has prevented the $\mathrm{Mu}$ jahedin from receiving greater international recognition and support. Lack of unity has prevented the Mujahedin from challenging the legitimacy of the Karmal regime in many international forums and drawing greater attention to Soviet atrocities in Afghanistan.

If it holds and consolidates, the alliance of the principal resistance groups formed in May 1985 in Peshawar has the potential to change this situation dramatically. The alliance, called the Islamic Unity of Afghan Mujahedin, ${ }^{51}$ has a supreme Council composed of the leaders of the seven constituent groups.

\footnotetext{
40 Nawa-i-Waqt (Lahore) July 25, 1980.

"Le Monde (Paris), Nov. 15-17, 1983, trans. in Joint Publications Research Service (hereafter JPRS), Near East/South Asia (Washington, DC), Jan. 11, 1984, p. 100.

${ }^{40}$ Al-Hawadith (London), April 18, 1980, in JPAS, Near East/North Africa, June 13, 1980, p. 15.

40 Jere Van Dyk, In Afghanistan: An American Odyssey, New York, Coward-McCann, Inc., 1983: Van Dyk quotes Rabbani as saying that Russia is "the first enemy; the West is the second," p. 63.

${ }^{30}$ On the Shiltes, see Oliver Roy, "Rise of Khomeynism among Shiite Minority," Le Monde Diplomatique, April 1983, quoted in JPRS, Near East/South Asia, June 8, 1983 pp. $56-60$.

s' Monthly Bulletin, May 1985.
} 
The position of spokesman for the alliance rotates among the seven leaders at three month intervals. The first spokesman was Khalis, followed by Hekmatyar. ${ }^{52}$ Currently, Gailani is spokesman. The alliance has a 49-member shora (assembly) composed of seven delegates from each group, a joint military committee, and six nonmilitary bodies (committees on cultural, political, refugee, education, information, and health affairs). A principal purpose of the alliance is to increase the political profile of the resistance. Perhaps the Mujahedin have finally recognized that a united front is a necessary precondition for their greater international presence.

In October 1985, the alliance sent a delegation of representatives from all seven groups headed by its spokesman -Gulbuddin Hekmatyar - to New York for the 40th anniversary of the United Nations. The delegation requested that the resistance forces rather than the Karmal government be given Afghanistan's seat at the UN..$^{53}$ The Mujahedin also intend to seek to represent Afghanistan in the Organization of the Islamic Conference (OIC), where Afghanistan has remained unrepresented ever since the Karmal government was in effect expelled. ${ }^{54}$ In January 1986, the alliance's spokesman Gailani headed a delegation to an OIC foreign ministers' meeting. The delegation was given high visibility at the meeting, but the issue of formal membership for the Mujahedin was deferred until the scheduled January 1987 meeting of OIC heads of state. OIC membership could be the first hurdle in the challenge of the Karmal government's right to represent Afghanistan in other organizations, including the UN.

The alliance is also intended to foster military coordination among the resistance groups. Relations among the partisan groups have at times been characterized by conflict, including actual fighting, during which hundreds of partisans have lost their lives. Although influenced by ideological differences, the discord has been fundamentally the result of the competition for domination and power among the seven leaders in Peshawar. Lack of a coalition had prevented the emergence of a single overall military command and joint planning in the war against the Soviets. It had often led to misunderstandings and fights for the spoils of victory, as well as premature claims of victory.

Lack of alliance among the seven major parties had also hindered the organizational development of eacil

\footnotetext{
52 Afghan Realities, Oct. 16, 1985.

${ }^{53}$ The Wall Street Journal (New York), Nov. 1, 1985

se Afghan Realities, Oct. 16, 1985, p. 2.
}

of the individual parties. Commanders in the field felt no need to follow the orders of party leaders, since they could always go to other parties if they were unhappy with their own leader. To change the relative power in favor of his group, an individual leader often sought to subvert the other parties and to "buy" the others' commanders. In order not to lose commanders to rivals, leaders tended to tolerate incompetence and even corruption. In turn, commanders faced similar problems in relation to their fighters. The lack of cooperation among the parties, and actual fighting among them, had lead to a considerable loss of popularity for the seven leaders among the Afghan population.

Even with the current alliance, many sources of conflict remain among the Mujahedin. Thus, a major task of the new joint military committee of the alliance is the prevention or at least the containment of these conflicts. Its additional purposes are to: (1) coordinate a military strategy and a weapons distribution system congruent with the strategy; (2) develop a program to protect supply routes; (3) improve the capacity to prevent infiltration by Kabul's agents; (4) establish joint training for Mujahedin and improve the quality of training; (5) develop common strategies to counter major Soviet military moves.

A number of resistance organizations and commands inside Afghanistan are already well organized and cooperate with one another despite political differences. Among the internal regional commands, the most effective appear to be those led by young and educated commanders, such as Panjshir's Massud, Herat's Ismail Khan, Jalaluddin in Paktia, and Abdul Haq in Kabul. ${ }^{55}$ If the alliance functions effectively and broadens to encompass military coordination, the less well-organized groups might emulate the methods of these younger commanders and become more effective in their own areas.

In order to prevent the Soviets and the Karmal regime from succeeding in emptying the Afghan countryside, the Mujahedin-besides increasing their capabilities in important regions-need also to develop basic social institutions. In many parts of Afghanistan, the Mujahedin are the only authority. Yet the resistance is not in a position to provide the population of those areas with emergency relief services. Assisting the local population in developing social programs could intensify ties between the local population and the resistance organizations. It might

ss The Washington Post, a six-part series in October 1983; Monthly Bulletin, June 1983, pp. 6-8. 
even enable some refugees to return home. Should the Mujahedin develop a joint social service program in liberated areas, it would further strengthen the alliance and undermine the prospects for Moscow's Sovietization program.

\section{The International Dimension}

Soviet attempts to eradicate the resistance in Afghanistan have been coupled with efforts to bring about the abandonment of the Mujahedin by their friends in the international community. The Soviets have striven to isolate the issue of Afghanistan and thus to prevent events there from affecting the Soviet Union's relations with other countries. Moreover, Moscow is using various propaganda tools to try to convince the world that the Karmal government is "legitimate" and that the war in Afghanistan was precipitated by and goes on because of "foreign interference," meaning support for the Afghan resistance. ${ }^{56}$

Soviet efforts have been partially successful. Although the sanctions imposed on the Soviet Union after the invasion were in force longer than was the case with sanctions for any other post-World War II transgression, most of them have long since been lifted. Few significant international agreements with the Soviet Union have been delayed over Afghanistan. The Soviet-imposed regime of Babrak Karmal occupies Afghanistan's seat in all international forums except for the Islamic Conference. In the UN-sponsored negotiations on Afghanistan, it is the Karmal government that is party to the indirect talks with Pakistan The mass media in many countries use Soviet terminology in discussing Afghan developments. Thus, the resistance is almost invariably referred to as "the rebels," implying that the Mujahedin are fighting against the legitimate government.

Recently, however, support in some key countries for the resistance in Afghanistan has increased. This includes greater support in the United States Congress, which recently authorized overt humanitarian assistance for the first time. ${ }^{57}$ Since American support for the Mujahedin's military operations remains covert for the most part, one cannot be certain about the overall magnitude of US assistance to the Mujahedin. The Soviets themselves have claimed that Washington has spent US $\$ 300$ million in support of the Afghan partisans during the first four years of the SovietAfghan war and intended to spend $\$ 130$ million in $1984 .^{58}$ The Washington Post reported that for the 1985 fiscal year Congress allocated $\$ 250$ million for the Afghan program. ${ }^{59}$

But the countries that have the most influence on developments in Afghanistan are its immediate neighbors. Fully aware of this, the Soviet Union has increased pressure on both Iran and Pakistan in the hopes of changing their policies with regard to the war

\footnotetext{
${ }^{56}$ International Herald Tribune, (Paris), Dec. 4, 1984, p. 1

${ }^{37}$ Policy Forum (Washington, DC), Vol. 2, No. 18, October 1985

${ }^{58}$ Bradsher, "Afghanistan," toc. cit., p. 46.

59 The Washington Post, Jan. 13, 1985.
}

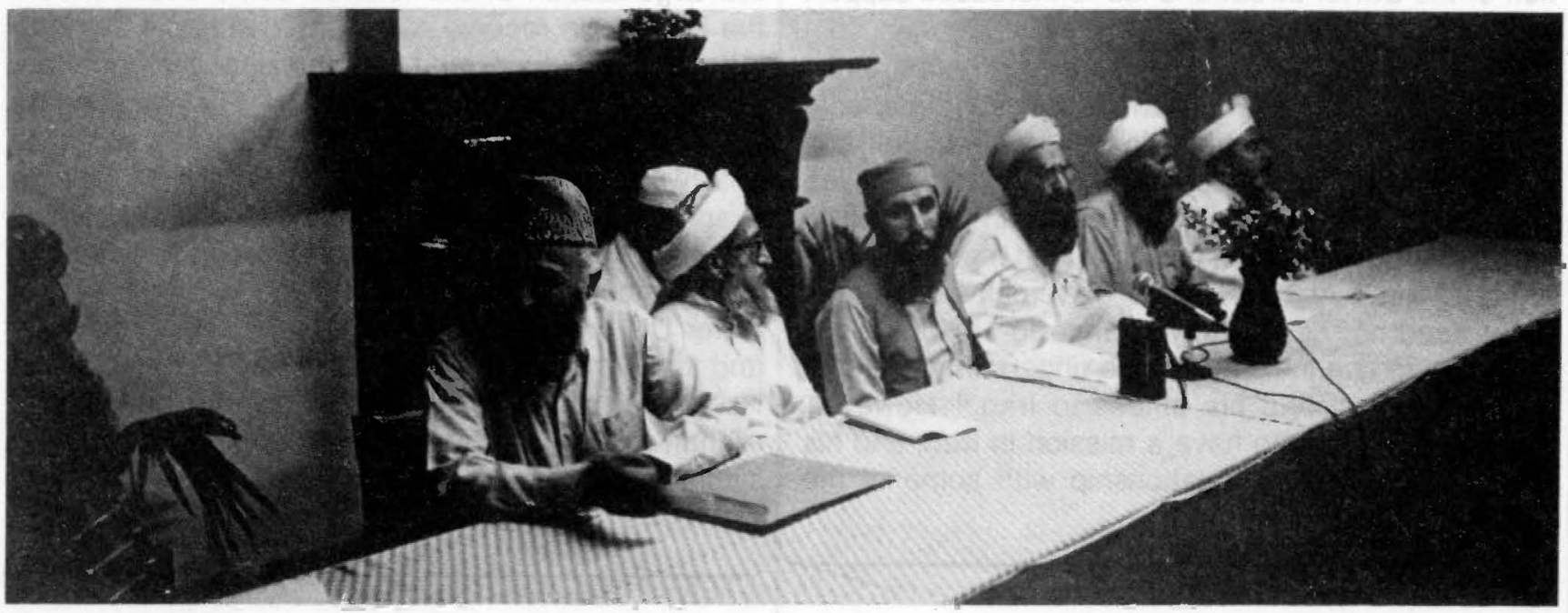

Leaders of Afghanistan resistance parties at a 1985 meeting in Peshawar, Pakistan: from left to right, Abddur Rasoul Sayyaf (partly hidden), Burhanudin Rabbani, unidentified (hidden, at rear), Sebghatullah Mojadeddi, Gulbuddin Hekmatyạr, Nabi Muhammadi, Yunus Khalis, and Ahmad Gailani. 
in Afghanistan. Pakistan has experienced a marked deterioration in its relations with Moscow. President Mohammad Zia-ul-Haq was given a stern lecture by the new Soviet leader Mikhail Gorbachëv about Pakistan's Afghanistan policies when the two met at Konstantin Chernenko's funeral. To increase the pressure on Islamabad, Moscow has also sought - unsuccessfully - to prevent an improvement in Indo-Pakistan relations by making repeated suggestions that Islamabad masterminded the Sikh opposition to New Delhi sought a nuclear capability against India; was becoming an American military base, and thus was tipping the regional balance of power against India. ${ }^{60}$

Up to now, these pressures on Islamabad have failed to bring about any fundamental change in Pakistani policy, although there are voices in Pakistan calling for a change. Moscow is counting on Pakistan's domestic divisions to influence the government to come to terms with the situation in Afghanistan. As noted earlier, it is also active among the tribesmen in Pakistan's North-West Frontier and Baluchistan provinces.

For Iran, the war in Afghanistan has been a significant factor in negatively affecting relations with the Soviet Union. Iranian support for the Afghan resistance has focused largely on the Shiites, who constitute some 20 percent of the Afghan population. The Soviets and the Kabul regime have at times shown their displeasure at Iranian support by carrying out cross-border military operations. Such operations against Iran first took place in 1982. Rather than intimidating Iran, they heightened the Iranian perception of the Soviet threat and led to increased support for the Afghan Mujahedin. ${ }^{61}$

Recently, the Soviets have sensed an opportunity to improve relations with Iran. Tehran's international isolation and need for arms for the Iran-Iraq war has led Moscow to expect less hostility from Iran. Yet, so far Iran has not changed its policies in return for a significant betterment of relations with the USSR. The future of Iran's Afghanistan policy remains uncertain, but it need not necessarily change to Moscow's advantage. As one indicator of the uncertainty, Hekmatyar recently closed his offices in Iran. ${ }^{62}$ However, Rabbani continues to have a mission in Iran, and his group has a working relationship with some of the

6o Foreign Broadcast Information Service, Daily Report: Soviet Union (Washington, DC-hereafter FBIS-SOV), Feb. 22, 1984.

61 Zalmay Khalilzad, "Islamic Iran; Soviet Dilemma," Problems of Communism, January-February 1984 , pp. 1-20

B2 Interviews by author, autumn 1985 .
Iranian-backed resistance groups. The Mujahedin are looking for partners among the Shiite resistance.

The People's Republic of China is another neighboring state affecting the war in Afghanistan. Although it is improving its relations with Moscow, Beijing has not given up supplying arms to the Afghan resistance. Also, although the Chinese during 1985 had softened their position with regard to the need to resolve the Afghan conflict as one of the three preconditions for any improvement in Sino-Soviet relations, the most recent Chinese statements seem to imply that meeting all three preconditions is again their requirement of the Soviets. ${ }^{63}$

Islamic states, whether neighbors or not, have generally been supportive of the Mujahedin. The role of Saudi Arabia has been especially substantial. One resistance group, Sayyaf's Islamic Alliance, has close ideological and financial ties to the Saudis. Both the government and semi-private groups in Saudi Arabia, such as the Mecca-based World Muslim League, provide significant financial support to the Mujahedin. However, two Saudi allies, Oman and the United Arab Emirates, recently established diplomatic relations with Moscow. Pressure on the Saudis to follow suit is increasing. It is conceivable that Riyadh could make Soviet withdrawal from Afghanistan a condition for the establishment of these ties with Moscow.

But Saudi Arabia and Pakistan are also crucial for helping the Mujahedin gain greater international legitimacy. For example, if the new alliance of the Afghan Mujahedin consolidates, Saudi Arabia might support the demand by the Afghan fighters for membership in the Organization of the Islamic Conference. Should the Mujahedin receive such formal support from the Muslim world, they could then press for greater attention to the Afghan cause at the UN. For example, no UN Security Council meetings have been called to deal with military offensives against the Mujahedin even when these involved major attacks on civilian targets. The Mujahedin could encourage sympathetic UN members to call for such meetings in the future. Other UN organs, such as its public affairs program and the 4th Committee (which deals with colonial issues) might also begin to give greater attention to Afghan-related matters. The alliance also enables sympathetic countries to deal at a high political level

\footnotetext{
${ }^{33}$ For a recent statement, see Foreign Minister Wu Xueqian's report before the National People's Congress Standing Committee, Jan. 16, 1986, trans. in Foreign Broadcast Information Service, Daily Report: China (Washington, DC), Jan. 17, 1985 pp. $\mathrm{K} / 1-15$
} 
with the Mujahedin without fear of favoring one resistance group over another. Ultimately, an effective alliance could give the Mujahedin a voice in negotiations dealing with Afghanistan.

\section{UN Proximity Talks}

Presently, the formal negotiations on Afghanistan are the "proximity" (indirect) talks between the Kabul government and Pakistan. These talks, which have been held periodically since 1982 , are sponsored by the United Nations. The talks have gone through several phases, during which conflicting proposals were made both on the format and substance of a settlement. In December 1985, reports were issued that the two sides had agreed that a settlement should consist of four instruments. ${ }^{64}$ Reportedly, Kabul and Islamabad have already reached agreement on three of the four documents comprising the settlement. The first document deals with what is called "noninterference and non-intervention," and is to be ratified by Islamabad and Kabul. This instrument will require the end of outside assistance to the $\mathrm{Mu}$ jahedin, especially by Pakistan. Presumably, Kabul will undertake not to interfere in Pakistani affairs, by ceasing to support Pashtun and Baluch separatists and tribal opponents of Islamabad, and thus implicitly recognize the disputed border between the two countries - the Durand line.

The second document deals with international guarantees of the settlement. The two sides have agreed that Washington and Moscow should be the guarantors of an Afghan settlement. The United States has announced its willingness "to play an appropriate guarantor's role in the context of a comprehensive and balanced settlement," and has informed the UN that it finds this document acceptable. ${ }^{65}$ The American declaration reversed an earlier posture by which Washington would not support any one component of the settlement until the entire agreement was completed.

The third document focuses on the return of Afghan refugees to Afghanistan. According to the Pakistanis, before the refugees return to Afghanistan they will be consulted regarding the "conditions" acceptable for their return. which will be "voluntary." ${ }^{16}$ An agreement

" Unpublished paper by Abdul Waheed, Pakistan Ambassador to the Federal Republic of Germany, "Afghanistan-A Forgotten War," presented at a conference on Afghanistan sponsored by the Hanns-Seidel-Stiftung, Munich, Dec. 16-17, 1985; and The New York Times, Jan. 1, 1986

s Waheed, loc. cit. on the fourth instrument - which is to set out the interrelationship between the first three documents as well as deal with the withdrawal of foreign troops - is yet to be reached. This document is expected to have specific dates as to when the withdrawal will begin and when it will be completed. The Kabul regime has refused to provide these dates so far. ${ }^{67}$ It reportedly has made the provision of these dates conditional on Pakistani acceptance of face-to-face negotiations in future talks. To Kabul, direct talks would mean that Pakistan, and therefore other states, accepts the Karmal regime as the legitimate government of Afghanistan. To date, Pakistan has not agreed. ${ }^{66}$

The insistence by Kabul on direct talks raises questions regarding Moscow's real attitude toward a "political settlement" in Afghanistan. That attitude could be one of several:

- Moscow might see the UN-talks as simply a means of lowering the political costs of its involvement while it continues to try to defeat the resistance militarily. Thus, to keep the talks going, Kabul will continue at Moscow's behest to make demands that are unacceptable to the other side.

- Moscow might be ambivalent about the negotiations. As it continues to intensify its military efforts, Moscow might view the talks as conceivably giving some legitimacy to the Kabul regime. If direct talks come about, Moscow might believe that a Sovietoriented regime could survive without the presence of Soviet troops.

- Moscow might be uncertain whether the Kabul regime would survive even if the Mujahedin stopped receiving outside assistance. Nevertheless, Moscow might feel that recognition by Pakistan would improve the chances of the Kabul government because such recognition could lead to tensions between Pakistan and the Mujahedin as well as induce some Mujahedin commanders to join the government.

- Moscow might be calculating that if the Kabul regime becomes "legitimated," it could call in Soviet troops to help against persisting Mujahedin opposition. Moscow could do so at a considerably smaller political cost because the Mujahedin would be much

6 Ibid.

${ }^{67}$ The New York Times, Jan. 1, 1986; and The Christian Science Monitor, Jan. 2, 1986.

The New York Times, Jan. 1, 1986 
less formidable without Pakistani support and the world outcry would be considerably smaller since the number of Soviet troops needed would not have to be as large as it is now.

It is highly probable that Moscow believes that Pakistan's acceptance of the Kabul regime would significantly increase its chances of survival. Therefore, in order induce Pakistan to talk directly with the Kabul regime, the Soviets have been bringing about changes - largely cosmetic - in the Kabul government. Their purpose is to convince the Afghan population, Pakistan, and world opinion generally that the Kabul government is broadening the bases of its support. The Soviets have urged the Kabul government to "create an atmosphere of positive dialogue between the public and political forces, including those who so far stick to positions hostile to the revolution." 69

Karmal has implemented these desiderata by appointing a few Afghans who do not have formal PDPA affiliation to prestigious positions in the government. For example, two persons without party affiliation were appointed to ministerial positions: Abdul Basir Ranjbir was named head of the central bank, and Mohammad Daoud Kauian was appointed head of the Bakhtar News Agency. There are rumors that more noncommunists will be appointed. In January 1986, the Revolutionary Council was broadened to include some non-party members. ${ }^{70}$

However, both the Soviets and Karmal's government continue to maintain that the 1978 coup, which brought the communists to power, is irreversible. They have not demonstrated any serious desire to negotiate directly with the partisans or to agree to a mechanism through which the Afghan people could express their preferences regarding the kind of government they might want. Even though a few noncommunists have honorific positions, Moscow and Kabul appear determined to keep control over the ministries of defense and interior, KHAD, and similarly crucial institutions.

Even if Kabul were to provide the dates for a Soviet troop withdrawal without direct talks with Pakistan, there remain potentially serious problems with the present negotiations. First, since they do not directly include the Mujahedin, the partisans have opposed these talks for fear that Islamabad might agree to

* Pravda (Moscow), Nov. 10, 1985, trans. in FB/S-SOV, Nov. 18, 1985, p. D/1.

${ }^{70}$ Foreign Broadcast Information Service, Daily Report: South Asia (Washington, DC), Jan. 22, 1986, p. C/1. something unacceptable to them. ${ }^{71}$ The danger of a split between Pakistan and the resistance on the terms of a political settlement is serious. Islamabad might implicitly (or explicitly) agree to accept a communist-dominated government in Afghanistan and stop supporting the Mujahedin in exchange for a promise of Soviet withdrawal and the willingness of the Kabul government to take back the Afghan refugees. The Mujahedin are likely to reject such a formula since the removal of the communist-dominated government is one of their principal demands. To achieve it, at least some of the Mujahedin are likely to continue their resistance even without Pakistani support. Yet without Islamabad's support, the Mujahedin would be dramatically less effective, and thus make it possible for Moscow and its local surrogates to overcome an increasingly weak opposition. Moreover, if continued opposition became threatening, Moscow might "delay" the withdrawal of some of its troops or even bring in more troops at the "invitation" of a "legitimate" government. Such a move might be perceived by many as entirely proper.

Second, Iran is not a party to the UN talks and might oppose an agreement concluded by Pakistan. Iran has refused to participate because the Mujahedin are not represented. Pakistan and UN negotiator Diego Cordovez have kept the Iranians "informed," but Tehran's attitude to the negotiations is not known. Should Tehran oppose the agreement, it might continue support for the Mujahedin resistance, which in turn might move closer to Iran. Even if Iran were not to supply major weapons to the Mujahedin, the Soviet Union might take a negative Iranian official position to be a reason for delaying or stopping its troop withdrawal. Given Iran's unpopularity in the international community, the Soviets' move would probably elicit. only a muted world reaction.

But the basic problem with the talks is that Moscow's fundamental position on Afghanistan remains unchanged. It does not accept the Afghan population's right to self-determination. So far at least, the talks serve Moscow to reduce its costs of establishing a communist-dominated, pro-Soviet government in Kabul. Should Moscow accept the Afghans' right to self-government, it could easily find a "facesaving" way out of Afghanistan. Its refusal to do so is undoubtedly conditioned by what Moscow perceives to be its strategic stakes in Afghanistan.

\footnotetext{
"The Soviets, aiso, are not represented at the taks. They have at times sent an official to Geneva to give on-the-spot instructions to the Kabul delegation, and the
} Mujahedin, on occasion, have been briefed by Pakistan. 


\section{Soviet Stakes in Afghanistan}

Apparently, the Soviet leadership remains convinced that a Soviet withdrawal from Afghanistan and the establishment of a noncommunist regime there would damage Soviet prestige and have adverse repercussions elsewhere. It also must expect that a victory in Afghanistan would bring very significant advantages to the Soviet Union. Although Moscow's perception of damage to its interests from a failure in Afghanistan is probably exaggerated, it nevertheless plays a role in Soviet persistence. Accepting defeat in a country where, because of territorial contiguity and past and present investments, substantial interests are involved, could undermine the legitimacy of Soviet domination elsewhere and lead to the questioning of Soviet capability and resolve. Undoubtedly Moscow has its own domino theory, making a retreat very difficult. Western support of the resistance might be taken by Moscow as an indication that Western powers would insist on gaining influence on security issues in Afghanistan if the communist regime fell. The Soviets have repeatedly made the argument that - had they not invaded Afghanistan - the United States would have turned Afghanistan into an

${ }_{22}$ For Soviet and Kabul regime statements, see Ministry of Foreign Affairs, White Book: Pakistan Subversive Activities Against the Afghan Revolution, Moscow, Novosti Press Agency, 1980
American military base..$^{22}$ Given the Soviet perspective on world politics, this notion probably finds some credence in Moscow.

Soviet domestic factional politics reinforce external considerations for not withdrawing from Afghanistan. The reluctance of any single leader during a succession period to consider withdrawal from Afghanistan reflects a desire to avoid personal responsibility for a setback there. Being associated with failure could encourage challenges by rivals. Soviet activities in Afghanistan since Gorbachëv's coming to power are characterized by continued application of force.

Another factor deterring Moscow from leaving Afghanistan is the Soviet expectation of significant gains from a victory there. Soviet credibility would be strengthened by a demonstration that it supports its friends and stands firm in the face of pressure. Not only would the Soviets add a country the size of France to their satellite empire, they could also use Afghanistan as a base for subverting neighboring countries, such as Iran or Pakistan. A Soviet victory would also have important geostrategic implications for the Persian Gulf by improving Moscow's ability to project power there.

The question of potential Soviet gains from secure access to Afghan military facilities has been a controversial one. Immediately after the Soviet occupation many analysts, including several senior officials in the Carter administration, argued that the Soviets had made significant gains in their ability to massively

\section{Table 1: Potential Soviet Force Projection Great Circle Distances from Soviet and Afghan Bases to Key Persian Gulf Cities}

(in kilometers)

From USSR

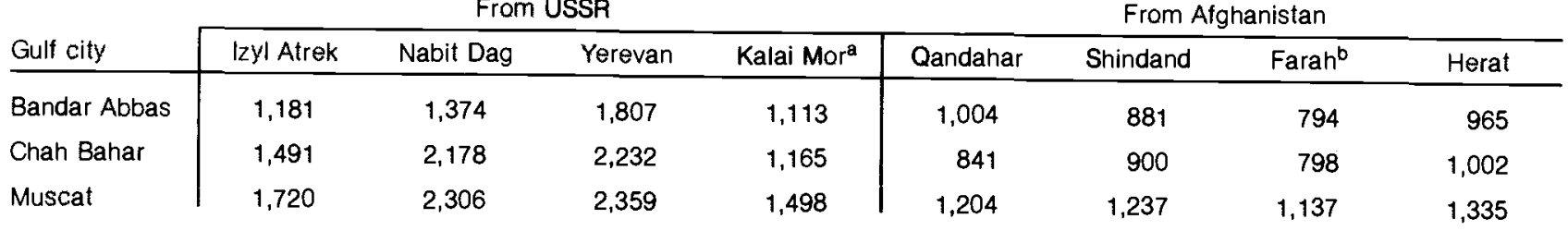

\section{Estimated Combat Radii for Selected Soviet-bloc Aircraft ${ }^{c}$}

(in kilometers)

\footnotetext{
MiG-21 .........635 MiG-23 ......... 1,150 MiG 25 (A and E) . . . 1,260

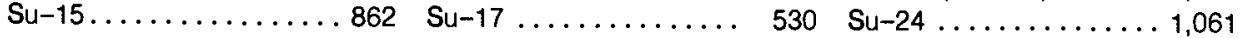

MiG $27(\mathrm{D}$ and $\mathrm{J}) \ldots \ldots \ldots . \ldots 795$

Yak-28.............. 925

${ }^{a}$ Possible Soviet airfield inside the Soviet Union.

${ }^{b}$ A helicopter airfield here could be expanded to accommodate other aircraft.

${ }^{\mathrm{C}}$ Estimates of combat radii vary. The highest and lowest estimates have been averaged here.
}

SOURCES: Aibert Wohlstetter, et al., Interest and Power in the Persian Gulf, Los Angeles, CA, Pan Heuristics, 1980; and US Department of Defense, Soviet Military Power. Washington, DC, US Government Printing Office, 1985. 


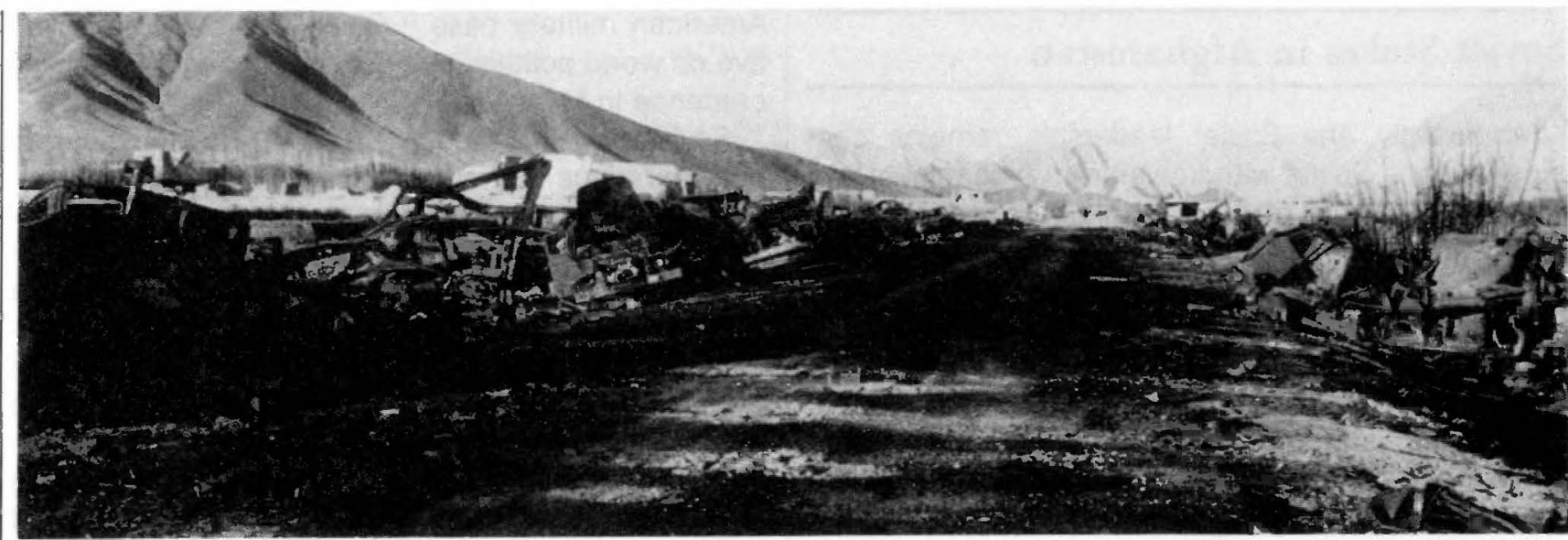

Wreckage of a Soviet convoy destroyed on the highway from Gardez to Kabul in 1983.

- Kouwenberg \& Versteeg/SYGMA.

threaten Southwest Asia and the Persian Gulf. Some argued that this consideration was probably a major motivating factor for the Soviet action. Over time, this interpretation has been replaced by another extreme analysis that attributes no significant effect on Soviet ability for power projection to the Gulf. ${ }^{73}$

The perception that Afghanistan was a first step in a general Soviet expansion in the region was clearly exaggerated. However, so is the belief that the occupation of Afghanistan does not change the Soviet capability to project power. It is unlikely that the invasion was primarily motivated by the Soviet Union's desire to better its power projection capabilities, but it is equally unlikely that Moscow was unaware of this possibility. The confusion in the West about the regional implications of relative Soviet capability is largely due to the fact that the Soviet presence in Afghanistan has different implications for different parts of the Gulf. The invasion has not changed Soviet power projection capability as far as the upper Gulf (Iraq, Kuwait, United Arab Emirates, and Saudi Arabia) is concerned. Bases in the Soviet Transcaucasus region are closer to this area than are existing or potential bases in Afghanistan. However, bases in Afghanistan have improved Moscow's ability for projecting power to the lower Gulf and the Arabian Sea, including the Strait of Hormuz, parts of Iran and Oman, and the whole of Pakistan. (See the data in Table I on page 17.)

${ }^{73}$ For a detailed discussion of potential Soviet gains from bases in Afghanistan, see Zalmay Khalitzad, "The United States and the War in Afghanistan," in Leo Rose and Noor Hussein, Eds., United States Pakistan Relations, Berkeley, CA, University of California Press, 1985
Given their perceptions of gains and losses from victory or failure in Afghanistan, it is not clear, whether the Soviets will leave this unfortunate country under any circumstances. The first precondition for Soviet departure would be a much stronger Afghan resistance capable of dramatically increasing the costs of Soviet occupation. Only if Soviet leaders are persuaded that time is not on their side in the long run, might they begin to consider seriously a settlement that would allow self-determination to the Afghans.

\section{Soviet Options}

The Soviets could respond to more effective resistance efforts either by continuing the present level of involvement, escalating, or deciding on some form of disengagement. In the short run, they are likely to continue the 1984-85 strategy, although there is a chance of escalation.

Escalation would certainly make life more difficult for the Afghan resistance. However, a substantial in. crease in the number of Soviet troops (perhaps another 100,000) would also greatly increase the costs of occupation. Furthermore, almost doubling the number of Soviet troops in Afghanistan would draw more attention to the situation as a whole and could negatively affect Soviet ties with key countries, including the United States, at a time when Moscow is seeking expanded economic ties and new arms control negotiations.

An escalation of the war, including the use of more brutal tactics, would also be likely to lead to intensified military activities by the resistance against Soviet strongholds. International friends of the Mujahedin 
might respond by increasing their support, as they have done in the past. Clearly the Soviets would be able to hurt the Afghans more than vice versa, but the result could be greater Afghan hatred for the Soviets. If the alliance among the Mujahedin holds, the Afghans might also be able to exact a much higher political price for the Soviet occupation than has been the case in the past.

In another possible scenario of escalation, the Soviet Union might increase pressure on Iran, but especially on Pakistan, to abandon the Afghan resistance. As already mentioned, Soviet relations with Pakistan remain tense and Soviet propaganda against Pakistan is increasingly hostile. Greater Soviet pressure on Pakistan could take several forms. First, Moscow might increase its efforts to destabilize Pakistan politically. ${ }^{74}$ Such efforts have not had much success so far however, and an active Soviet policy of destabilization runs the risk of undermining the very tribes and parties in Pakistan that are more receptive to Moscow than the current regime. The Soviet invasion of Afghanistan actually strengthened President Zia's position. Evidence of significant efforts at destabilization might be seen by many Pakistanis as an indication of a Soviet plan to use Afghanistan as a base for expanding in the region. Nevertheless, Moscow is likely to pursue the destabilization option before fundamentally changing its policies on Afghanistan.

Second, Soviet escalation might take the form of direct military pressure through air strikes against major Pakistani targets. Successful attacks could increase opposition pressure on President Zia to come to terms with the Soviets. However, it could also increase pressure on the government to respond decisively. The Pakistani air force recently brought down an intruding aircraft. ${ }^{75}$

Soviet military pressure could also force Pakistan to seek closer security relations with the United States, something Moscow does not want. It could dispose Washington, at the very least, to increase its military supplies for Islamabad. Already, in response to a Soviet cross-border attack against purely Pakistani targets in 1985, the Reagan administration expedited the shipment of sensitive air defense equipment to Pakistan. ${ }^{76}$ Washington has also indicated to the Soviets that direct military pressure on Pakistan can have significant repercussions on the state of SovietAmerican relations.

\footnotetext{
"This section draws on my "The Soviet Dilemma in Afghanistan"" loc. cit.

${ }^{75}$ The Washington Times, Jan. 16, 1986.

7t The New York Times, May 12, 1985.
}

Third, major military incursions into Pakistan are a possibility, including, perhaps, the takeover of Pakistani territory for a period of time. The Soviets might justify such action as being directed against Afghan refugee camps in Pakistan. For Moscow to carry out such operations against Pakistan, however, major logistical preparations and the formation of supply lines would be necessary. These would be visible and could be vulnerable to attack. In sum, a substantial investment of resources would be required for Moscow to mount a significant territorial incursion into Pakistan. Should this occur, Pakistan, which has a 500,000 man army and some very modern equipment, including F-16's, would be likely to resist - as did the Iranians in 1982.

A Soviet attempt to hold Pakistani territory would probably lead to a major crisis in American-Soviet relations. The Reagan administration takes pride in having restored a strategic relationship with Islamabad. Thus a Soviet attack against Pakistan would be viewed as a major challenge by the United States and could lead to a major confrontation. International censure would also increase dramatically. A Soviet attack would damage Moscow's tenuously better ties with China, which has a long-standing security relationship with Pakistan. Clearly then, this is a very risky option for the Soviet Union.

\section{Prospects}

In the aftermath of the Geneva summit between President Reagan and General Secretary Gorbachëv, there has been much speculation that peace might be at hand in Afghanistan. Unfortunately this does not appear likely. Moscow still insists that Afghanistan should be dominated by pro-Soviet communists. The Mujahedin still reject this Soviet goal. Even an agreement between Pakistan and the Kabul government need not spell an end to the war.

It is possible that when Moscow realizes that neither escalation against the Mujahedin and neighboring countries nor the current negotiations will result in a communist-dominated Afghanistan, it might begin to consider other alternatives. It is not selfevident that the Soviets would never accept anything short of total military victory. In the past, the Soviets have changed their minds, and they may do so again.

Several compromises appear feasible. Some observers have suggested that the post-World War II settlements on Finland and Austria provide useful examples of what might be achieved. However, given the many unique features of the Afghan case, if the 
Soviets ever do accept a political settlement and withdraw, a new and different precedent will thereby be set.

Former National Security Advisor Zbigniew Brzezinski has proposed a formula of compromisenamely, the external neutralization of Afghanistan combined with a Soviet military withdrawal, the introduction of Islamic peace-keeping forces for an interim period, and self-determination for the Afghans. ${ }^{77}$ An arrangement that guarantees Afghanistan's neutrality would ensure that Afghanistan would not become a security threat to the Soviet Union. The neutralization formula deals with Soviet fears of American strategic designs on Afghanistan. Moscow could even claim victory, were such an agreement reached, by asserting that it has achieved one goal for which it invaded Afghanistan in the first place. A settlement of this type might be achieved through current or modified UN-sponsored negotiations that allowed the Mujahedin to have some representation.

The Soviets and their friends - and even some independent analysts - have occasionally charged that Washington prefers the continuation of the war to a political settlement. Such charges are based on the recognition that Soviet involvement in Afghanistan offers propaganda advantages to the United States and keeps the Soviet Union entangled in a protracted and

7 The New York Times, Oct. 6, 1985.

"See, e.g., the articles by A. G. Noorani, "India's Policy on Afghanistan," Indian Express (New Delhi), June 14 and 15, 1985. bloody conflict. Until recently, even some responsible governments, including India's, had voiced such opinions. Recent Indian press reports, however, show that New Delhi now accepts that Washington is seriously interested in a political settlement. ${ }^{78}$

In bilateral talks on Afghanistan in 1982 and 1985, and on other occasions, the United States has indicated to the Soviet Union that Washington will not create obstacles to a Soviet withdrawal and a political settlement in Afghanistan. Yet Moscow has expressed distrust of American assurances, probably not least because its countercharges against the United States served its own propaganda purposes. It is important that available channels be used to signal periodically to Moscow that the United States is ready and willing to play a constructive role-should Moscow decide to consider seriously a settlement that includes self-determination for the Afghan people.

Ultimately, however, two factors will have crucial influence on the Soviet decision. One is the military strength and the popular support of the Mujahedin in Afghanistan. The other is the level of international support (especially Pakistani) extended to the Mujahedin. The latter is partly contingent upon the maintenance and strengthening of the alliance among the resistance groups. Only when Moscow is convinced that it cannot get its way by military force, will it pursue solutions that encompass self-determination. Moscow has yet to reach that point. 


\title{
China's Economic Experiment: From Mao to Market
}

\author{
Jan S. Prybyla
}

fter a brief, turbulent period of a market-plan economy with mixed private/socialized property in the early 1950's (the political equivalent of which was Mao's "New Democracy"), ${ }^{1}$ the Chinese adopted Stalin's model of a centrally planned command economy with comprehensive state/collective property. The installation of this model was completed in 1956, toward the end of China's First Five-Year Plan (1953-57). Almost as soon as it was in place, however, the model was found to be ill-suited to China's conditions. The Stalinist emphasis on capital-intensive heavy industrialization at the expense of agriculture produced many problems: sluggish agricultural output and labor productivity; sectoral disproportions; consumer-goods shortages and low consumption levels; bottlenecks in the supply of key inputs; retarded services; urban unemployment ( 25 percent of the urban labor force, or 8 million people, in 1957); and rigid, overcentralized bureaucratic structures and procedures. As a result, between 1957 and 1976 the model was subjected to "right" (1957, 1961-65) and "left" (1958-60, 1966-76) adjustments that caused violent swings in the economy, as well as in the political and social lives of the Chinese people.

Jan S. Prybyla is Professor of Economics at The Pennsylvania State University (University Park). He is author of The Chinese Economy: Problems and Policies (1978, 1981), Issues in Socialist Economic Modernization (1970), and Market and Plan Under Socialism: The Bird in the Cage (forthcoming). He is a contributing editor of Current History, and a member of the editorial advisory board of Occasional Papers/Reprints Series in Contemporary Asian Studies, published by the School of Law, University of Maryland (Baltimore).
By 1976, the Chinese economy was in a bad state. While the poor quality of the country's economic performance was not new and had many dimensions, it was summed up in low and, for some time declining, factor productivity. ${ }^{2}$ Indeed, the 10 years of profound political upheaval during the Cultural Revolution merely added to the already long-term negative trend of productivity, which had averaged -1.5 percent annually since $1957 .{ }^{3}$ The growth in the net domestic product that had been obtained since the introduction of the planned economy in the mid-1950's (4.4 percent annually $)^{4}$ was due primarily to the addition of factors, especially labor, rather than to improvement in the efficiency of factor use. In fact, great damage was inflicted on land (through ecological abuse), labor (through educational obscurantism), and capital (through technological retardation), particularly in periods of leftward adjustment, such as the Great Leap Forward (1958-60) and the Cultural Revolution (1966-76). ${ }^{5}$ The result was poverty verging on destitution in large areas of China's countryside.

'Mao's New Democracy was an attempt to combine communist dictatorial politica forms with emasculated and restricted manifestations of political pluralism in a united front of communists and noncommunist "patriotic personnages." New Democracy was envisaged by Mao as a transitional phenomenon, the main function of which was to prepare the ground for proletarian dictatorship by the communist party. Like the transitional arrangements in the economy before 1953, it was a mix of incompatible elements. See Mao Tse-tung, "On New Democracy" (January 1940), in Selected Works of Mao Tse-tung, Bejing, Foreign Languages Press, 1965, Vol. II, PP. 339-84.

2 Total factor productivity is defined as the output per unit of labor and capital combined. For a discussion of factor productivity, see K. C. Yeh, "Macroeconomic Changes in the Chinese Economy During the Readjustment," The China Quarterly (London), December 1984, pp. 705-13.

${ }^{3}$ See Table 6 "Annual Rates of Growth of Domestic Product, Factor Inputs and Productivity, Selected Periods," in ibid., p. 711

4 Ibid.

${ }^{3}$ The following is just one of many examples of ecological abuse. In Inner Mongolia (Nei Monggol), the plowing up of grasslands during the Cultural Revolution's "take grain as the key link" campaign turned 967,000 acres of good pastureland into desert and resulted in 1.9 million acres' being invaded by sand. Between 1966 and 1978, the (continued on p. 22) 
The search for the causes of China's economic problems proceeded in two stages. The first, from 1976 through 1980, was characterized by pclitical housecleaning, ideological reinterpretations, and piecemeal economic adjustments. The formal beginning of the end of the first stage came in December 1978 with the holding of the landmark 3rd Plenum of the Party's 11th Central Committee at which Deng Xiaoping consolidated his hold on the party leadership. The consensus that emerged from the Plenum was that China's economic problems lay in the party and government's erroneous "style of work," which, it was said, had produced leftist distortions of the system of central administrative command planning. Thus, it followed that if this work style were rectified-through replacement of personnel plus some "education" - things would fall into place. In other words, what was needed was a simple adjustment. With time, the simplicity of the remedies and their lack of effectiveness became apparent. The second stage began in 1981 and is still going on. The consensus, apparently fragile, now seems to be that China's economic troubles are rooted in the system of central planning and that what is needed is reform.

An important conceptual distinction between "adjustment" and "reform" must be made at this time. Adjustment means policy changes within the framework of the given system. Adjustment-type changes do not alter in any fundamental respect the basic operational principles and institutional structure of the system. The opposite is true of reform. Reform changes the principles governing the system and the system's institutional arrangements for the generation, convey-

number of livestock in this autonomous region declined by half. Renmin Ribao (Beijing), Jan. 23, 1979; and Nei Monggol Regional Radio Station (Hohhot), Jan. 26, 1979, trans. in Foreign Broadcast Information Service, Dally Report: China (Washington, DC-

hereafter $F B(S-C H I)$, Feb. 2, 1979. For an overview of the ecological disaster in China wrought by leftward adjustments, see Vaclav Smil, The Bad Earth: Environmental Degradation in China, Armonk, NY, M.E. Sharpe, 1984.

The educational damage inflicted by the Cultural Revolution was both quantitative and qualitative. "Educational work suffered great setbacks during the 'cultural revolution' in the years 1966-76, and has not to this day fully recovered from the evil consequences" (Beijing Review, Jan. 1, 1981, p. 8). According to Hu Yaobang, general secretary of the Central Committee of the Communist Party of China, 160 million youths who were between the ages of 8 and 18 in 1966 (at the outset of the Cultural Revolution) received substandard, indeed "poisonous," education during the years of turmoil. Another 210 million teenagers in primary and secondary schools around 1980 were being given deficient education as a result of the destruction wrought by the Cultural Revolution. Ibid., Apr. 14, 1980, p. 15. In 1978, in a population exceeding 960 million, China had a total of 4.3 million scientific and technical personnel in engineering, scientific research, agriculture, public health, and teaching. The only relatively reliable ones were those whose skills were acquired before 1966. State Statistical Bureau, Statistical Yearbook of China 1983, Hong Kong, Economic Information and Agency, 1983, pp. 103, 525. For an update on the educational situation, see Marianne Bastid, "Chinese Educational Policies in the 1980 s and Economic Development," The China Quarterly, June 1984, pp. 189-219. ance, processing, and coordination of information about cost and utility, motivation, and distribution of property rights. Reform alters in a qualitative way the locus of decision-making in the system and the criteria for making the decisions. Thus, it marks the system's transformation into something qualitatively different. For reform of a centrally planned economy to deserve its name, the market and private property must become the dominant determinants of production, investment, and the distribution of income shares in the system. ${ }^{6}$

\section{Policies of Adjustment}

Between 1976 and 1980, four major adjustment policies were implemented. First, the administrative structure of the plan, flattened by the leftist hurricanes of the Cultural Revolution, was rebuilt and righted. Among other things, administration of the economy was simplified and decision-making was devolved to local authorities and industrial managers.' Second, the system's goal priorities were reordered primarily to benefit agriculture and consumer-goods industries, as well as to create a more open economy (in particular vis-à-vis the West). Third, emphasis was put on the importation of modern engineering technology from capitalist countries, in order to help modernize the technologically retarded Chinese plants and equipment. Fourth, and potentially most significant, selected elements of capitalist social techniques ${ }^{8}$ were imported and used as supplements to the command plan ("using capitalism to build socialism").

The fourth adjustment policy raises the interesting question of whether social techniques are systemical-

- The transformation thesis explicitiy rejects the convergence notion of market socialism in which market and plan harmoniously fuse in roughly equal proportions. the one aiding and rounding off the other. I find the convergence notion to be theoretically unsound and operationally unattainable.

'See Robert Michael Field, "Changes in Chinese Industry Since 1978," The China Quarterly, December 1984, p. 742.

as explained more fully in the text below, by resort to capitalist social techniques is meant the use of prices (including wages and interest rates), profits that depend on prices, and taxes to motivate workers and managers and to influence the spending patterns of consumers and investors, and the use of exchange rates in transactions with foreign countries. It also means that broad property rights with regard to assets are vested in the actual users of those assets. In a capitalist (market) economy, these techniques arise from competitive, lateral, buying and selling transactions concluded by freely choosing economic units. In a command economy, only the form of these techniques is used, without the substance. Thus, prices in a command economy setting are not the mathematical expression of costs and utilities in the system and do not even remotely indicate allocative rationality. Rather, they are accounting devices denoting - very roughly and imperfectly-production costs plus an arbitrary margin of profit. Property rights in assets vested in enterprise managers are subject to administrative restrictions regarding their value, size, use, and so on. 
Iy and culturally neutral. Is it possible to graft markets and de facto private property rights onto the central administrative command plan so as to improve the plan's efficiency, without reforming the planned system as a whole? Indeed, can capitalist social techniques be used to build a more efficient state socialism? Or, is it necessary to truncate such techniques, emasculate them, and restrict them in order to prevent them from fundamentally changing the state socialist system? More broadly, does the importation of capitalist social techniques produce behavioral ripples that transcend the economy and cause "spiritual pollution," for example, or "unhealthy tendencies"?"

The answer, of course, is that social techniques cannot be completely separated from the system from which they have evolved. Nor, in my opinion, can they be used disjointedly. They must be applied as a system, their organic interconnections unbroken. Capitalist social techniques, it can be argued, are the products of a pluralistic culture and as such need a pluralistic, competitive, free-wheeling, free-choice environment to do their job of efficient resource allocation. If such an environment is denied them, or if their essential interconnections are broken, they either atrophy or work in a perverse way. Indeed, ever since Nikita Khrushchev came to power in 1957, the Soviet and East European economies have borrowed capitalist social techniques, only to devitalize them and hem them in by the bureaucratic plan. Consequently, the efficiency results have been very small, nonexistent, or even negative. ${ }^{10}$

In China, like elsewhere in the world of the plan, the use of capitalist social techniques during the period of adjustment was intended to maximize reliance on "economic levers" rather than on "administrative levers." Unlike administrative levers, which are arbitrarily imposed from above, economic levers are indirect, general inducements to economic agents expressed in financial terms. Economic leverage

\footnotetext{
- The ethical principles of a socialist economy are listed by the Hungarian economist János Kornai as: (1) socialist wage setting (to each according to his work and equal pay for equal work); (2) solidarity (help the weak to rise rather than punish them through capitalist-like competition); (3) security (full employment guaranteed by society); and (4) priority of general interest over partial (individual) interest. See János Kornai, "The Dilemmas of a Socialist Economy: The Hungarian Experience," Cambridge Journal of Economics (Cambridge, UK), June 1980, p. 149. Kornai rightly concludes that conflicts are inevitable between these four ethical principles and the five conditions for economic efficiency, which are: (1) an incentive system to stimulate better performance from all individuals participating in production; (2) careful * calculation of costs and benefits and termination of nonefficient production activities; (3) fast and flexible adjustment to the current situation and external conditions; (4) entrepreneurship; and (5) personal responsibility.

${ }^{10}$ On the Soviet and East European borrowing of capitalist social techniques and its efficiency results, see Jan S. Prybyla. Market and Plan Under Socialism: The Bird in the Cage, Stanford, Hoover Institution Press, 1986.
}

means using prices (including wages and interest rates), profits that depend on prices, and taxes to motivate workers and managers and to influence the spending patterns of consumers. The economic agents adapt to those inducements at will; within the parameters set up by the levers, the agents have free choice. But to do the job of raising the efficiency of resource use, prices must be market prices, and markets must be workably (not necessarily perfectly, in a textbook sense) competitive. If prices are administered by government and/or party authorities whether central or local-and thus do not originate in reasonably competitive buyer-seller transactions, then they are merely administrative levers masquerading as economic levers: arbitrary prices arbitrarily imposed. "Administrative levers, whether in the form of physical commands or administered prices, cannot convey the multidimensional opportunity-cost information needed for efficiency of operations. In fact, they produce troublesome motivational effects.

The use of capitalist social techniques during the period of adjustment in China had two major characteristics: the various measures adopted were not organically linked into a logical, internally consistent system; and many of the measures were confined to certain geographical areas or to selected experimental enterprises. ${ }^{12}$ In other words, the capitalist social techniques were fenced off from one another and thus did not constitute an organic entity.

Nonetheless, the adjustments were quite comprehensive and affected urban as well as rural policies. State agricultural procurement prices (and abovequota prices) were raised, as were industrial tariff wages and salaries..$^{13}$ Later, the salaries of teachers and other "intellectuals" were also raised. Overtime and piecework pay and bonuses to enterprise managers, workers, and employees were reintroduced for the first time since the mid-1960's, and strict administrative restrictions on labor mobility were relaxed

\footnotetext{
" "The Retreat from Marx," The Economist (London), Oct. 27, 1984, p. 18. In China, "the assigned profit margin for making hot rolled steel is now ten times as high as for cold rolled steel. So the hot sort is naturally in surplus while the cold has to be imported at great cost. Yet rolled steel is one of the products [that] will stay subject to administrative decree" (ibid.). "

12 For example, it has been reported that since August 1984, 1,000 customs and security officials have manned around the clock the perimeter of the Shenzhen Special Economic Zone (near Hong Kong). South China Post (Hong Kong), May 29, 1985.

13 Tariff or basic wages and salaries are laid down-on the Soviet model-by the central authorities in schedules that are mandatory on state-sector enterprises. There are several such schedules. Industrial workers in China are generally subject to an eight-grade schedule, the skill and basic wage rate being spelled out for each job grade. State employees are under a different schedule containing roughly 30 eblary grades. There are separate schedules for engineering and technical persgrnep teachers, etc. See Jan S. Prybyla, The Chinese Economy: Problems and potojo, of, 2nd ed., Columbia, University of South Carolina Press, 1981, pp. 150-61

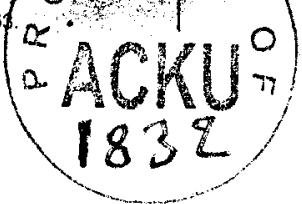




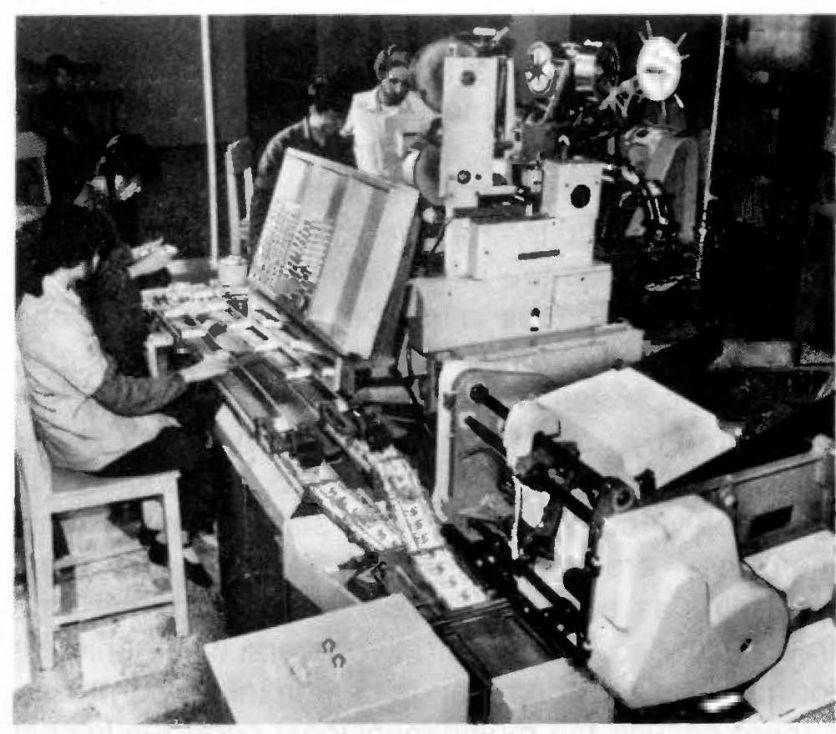

Manufacture of "Camel" brand cigarettes at the Xiamen Cigarette Factory in Fujian Province in 1981.

-EASTFOTO.

through a de facto termination of the rustication (xiafang) program, the gradual removal of rightist labels, and the encouragement of unemployable youths "awaiting work" to find work for themselves in the newly revived urban private sector or in cooperative industry and services. ${ }^{14}$

There were important structural changes in industry as well. Instead of the state appropriating 100 percent of state enterprise profits, experiments with

\footnotetext{
14 The xiafang movement, which peaked in the late 1960's and early 1970's, involved the compulsory transfer of educated urban youths (mainly middle-school graduates) to the countryside. Between 1968 and 1978, about 20 million urban youths were so relocated. The policy of rustication was quietly phased out in 1978-79, following the National Conference on Rusticated Youth Settling in the Countryside held in Beijing. Oct. 31-Dec. 10, 1978. Although most of the "sent down" youths returned to their home towns after this time, many apparently still remain stranded in the countryside, caught in inextricable red tape. See Charies Hoffmann, "Urban Unemployment in China," Asian Thought and Society (Oneonta, NY), March 1984, pp. 32-37.

Rightist labels were attached to many people, mainly intellectuals, during the Anti-Rightist Campaign of 1957 that followed the aborted Hundred Flowers Campaign. The consequences for an individual of being branded a rightist were terrifying. See, for example, Ruth Earnshaw Lo and Katherine Kindermann, in the Eye of the Typhoon, New York, Harcourt Brace Jovanovich, 1980. Removal of rightist labeis was ordered in 1975 , but the order was countermanded by the left faction within the leadership. The removal process was resumed shortly after the arrest of the so-called Gang of Four in , late 1976. See "Last Rightists have Their Designation Removed," Beiling Review, Nov. 24,1978, p. 3.

Urban unemployment, according to Hoffmann, loc. cit. (note 14, Table 2, p. 33), probably peaked at 13 percent of the urban labor force in 1979. The precise youth component of the 15 million urban unemployed in that year cannot be known with certainty, but it could be as high as three-fifths. According to Li Xiannian (report to a working conference of the Party's Central Committee, Apr. 25, 1979), the urban unemployment at that time stood at 20 million. Ming Pao (Hong Kong), June 14. 1979, p. 4. See also, John Philip Emerson, "Urban School-leavers and Unemployment in China," The China Quarterly, March 1983, pp. 1-16.
}

profits taxation, partial profit retention by enterprises, and enterprise incentive funds were initiated in selected places and firms. Special Economic Zones equipped with various legal forms of joint-venture or capitalist coproduction were also begun, and similar arrangements were made in the case of individual projects outside the zones. In the countryside, rural fairs (where near-market prices prevail) and household subsidiary plots were resurrected and expanded somewhat, and a production responsibility system subject to contract between the rural collectivity (production team) and small groups of households was initiated in 1979.

\section{Results of Adjustment}

Although the use of selected capitalist techniques has generally proven unsuccessful in the long run, such adjustments of the plan are not invariably a waste of time. They can, and sometimes do, improve certain dimensions of the planned economy's performance. They did that in China. Indeed, by 1980 , quantitative performance of industry and agriculture had shown marked improvement from the levels of $1975 . .^{15}$ However, the economy's qualitative ills re. mained by and large unaffected. In fact, the ad hoc use of emasculated and disjointed capitalist social techniques side by side with administrative orders of all kinds made the qualitative deficiences if not worse, at least more visible and less tolerable. Thus, hitherto suppressed inflation came more into the open; hidden unemployment came out of hiding; subsidies contin-ued to rise at fast rates; budgetary deficits appeared, as did balance of payments disequilibria; investment (especially outside the state budget) continued on its runaway course despite the central authorities' efforts to curb it; the production process was disrupted by persistent energy and transportation bottlenecks; a significant portion of state firms operated in the red; quality of output was deficient; and factor productivity showed little or no gain. Additionally, social indiscipline was on the rise, some people demanded more freedom of cultural expression and political democracy, and many people, especially the young, began to question the relevance of Marxism-Leninism. ${ }^{16}$ In

${ }^{15}$ For example, gross agricultural output rose from 128.5 billion renminbi in 1976 to 164. 6 renminbi in 1980. Over the same period, gross industrial output rose from 321.9 billion renminbi to 499.2 billion. See Statistical Yearbook of China 1983, op. cit. pp. 149 and 215

16 For a discussion of this view among youth, see Stanley Rosen, "Prosperity, Privatization, and China's Youth," Problems of Communism (Washington, DC), March-April 1985, pp. 1-28. 
these respects, China by 1980 had begun to encounter many of the same problems advanced socialist economies had experienced during their numerous experiments with adjustment of their highly centralized plans.

\section{Beyond Adjustment, Toward Reform}

The year 1981 marks a turning point in China's postMao economic history, although the turning had been some two years in coming. The period 1981-85 can be divided into two subperiods. From 1981 until the end of 1984, the agricultural economy underwent important changes in market relations and privatization of labor and property that skirted, and perhaps even crossed, systemic frontiers. While this was going on, the nonagricultural, or urban, economy (industry, commerce, services, transport, communications) was primarily still functioning under a policy adjustment, with experiments of a reformist temper being tried only in a selected but growing number of enterprises and geographical locations. Beginning in 1985, however, while the reform-like changes in agriculture were consolidated, the movement toward reform in the nonagricultural sector was stepped up, though not without stops and retreats. In 1985, therefore, experiments with free markets and privatization of labor and property began to be extended throughout the other sectors of the economy.

The decision taken by the party Central Committee in October 1984 to move beyond adjustment in the urban sector is official recognition of the need to bring the two major sectors of the economy into institutional harmony. ${ }^{17}$ It also is an implicit admission that qualitative improvement of economic performance must be sought through the use of market and privatization measures of reform, rather than through a return to the Stalinist plan in either its original (First Five-year Plan) version or in its modified 1961-65 form. A return to the no-market, no-plan solution of Maoism is not even under consideration.

\section{Agriculture}

The keystone of the institutional changes in agriculture, the element of change that constitutes a transition from adjustment-like tinkering with the parts to a reform-like replacement of the economic mechanism, is the contractual system of net-output delivery by households, or baogan daohu..$^{18}$ It is the culmination of an evolutionary process initiated in 1979 (but present in a somewhat different form in China during 1961-65) ${ }^{19}$ whereby the rural collective's operational unit, the production team (of some 30 to 40 households), signs contracts with its smaller component units for the delivery of given quantities and assortments of output at stated prices. These smaller units may be groups $(z u)$ of up to half a dozen households or individual peasant families $(h u)$. The production responsibility contract (zeren $z h i$ ) may be either an output contract (baochan zhi) or a net-output delivery contract (baogan zhi).

Under the terms of the output contract, the noncollective producing unit (the group or household) delivers the contracted-for output to the collective and receives workpoints for it. The value of a workpoint is determined by the collective effort of all production-team households in the context of the state's pricing policy, and the income distribution function rests, as before, with the production team (the collective). Under the net-output delivery contract, no workpoints are involved. The contracted-for output is delivered to the collective and paid for at prices specified in the contract. The balance remaining after the delivery obligation is fulfilled, the agricultural tax is paid, and a number of collective deductions are made remains the property of the household and can be consumed by the family, sold on the free market, or sold to the state at "negotiated" (near-market) prices. From the standpoint of the noncollective contracting unit, the evolution since 1979 has been from group to household. From the standpoint of the nature of the contract, the movement has been from output contract to net-output delivery contract. In other words, between 1979 and 1981, the progression was clearly in the direction of free market and the privatization of labor and use of land.20

The details and precise modalities of operation of the baogan daohu have been publicized and widely

17 "Decision of the Central Committee of the Communist Party of China on Reform of the Economic Structure, Adopted by the 12th Central Committee of the CPC at Its Third Plenary Session on October 21, 1984," Beijing Review, Oct. 29, 1984, pp. i-xvi. See also FBIS-CHI, Oct. 22, 1984, pp. K/1-17. For a discussion, see The New York Times, Oct. $21,1984$.

"A literal translation of Baogan daohu is "full responsibility to household."

"Two major differences between baogan daohu (1985) and the household contract system of 1961-65 should be noted. First, the 1961-65 system was less prevalent than the present one. Second, in a significant proportion of cases, the 1961-65 system involved payment in workpoints to the household by the contracting team or brigade (bacchan daohu), whereas no workpoints are involved in the present system (baogan daohu). In other words, the present arrangement represents a more widespread and profound decollectivization than did its 1961-65 predecessor (denounced during the Cultural Revolution as an evil creature of Liu Shaogi).

${ }^{20}$ Yak-Yeow Kueh, "China's New Agricultural Policy Program: Major Consequences, 1979-1983," Journal of Comparative Economics (New Haven, CN), December 1984, pp. 354-61, esp. Table 1, p. 356, and Table 2, p. 357. 
discussed and analyzed. ${ }^{21}$ Our interest here is in the systemic implications of this arrangement, that is, in its reform potential.

The arrangement amounts to family tenant farming, the landlord being the state (via the collectivity). Although no actual rent payment is involved, there is a quasi-rent element implicit in the net-output delivery obligation at state-set prices, which in the past were typically below-sometimes appreciably belowequivalent market prices. Legally, the land remains the property of the collective, and it cannot be bought or sold by the noncollective units. Such units, however, can obtain extensive (and exclusive) rights of use to the land, typically for a 15-year period (longer in the case of pastures and woodlands). Draft animals, farm machinery, and means of transportation can be owned privately by the families. Limited numbers of helpers (three) can be hired, but this restriction seems not to be closely enforced. The contract can be transferred to another family with the collective's permission, and compensation must be paid to the transferor by the transferee for any capital improvements made to the land. Consolidation of land parcels is also possible, again with the collective's consent. Under the contract, households may specialize in particular tasks, regardless of whether such tasks are agricultural or not (for example, transportation, machinery repair, merchandising).

From the standpoint of the system, the importance of baogan daohu resides in the de facto (not de jure) privatization of landed property (both de facto and de jure in the case of draft animals, machines, carts, trucks, and so on); the devolution of extensive (though far from unlimited) decision-making power, including decisions about income distribution and the voluntary establishment of cooperatives, to the level of a private production unit (the family); and the significant resort to market prices and near-market prices (negotiated prices) by both parties to the contract in deciding on the volume, assortment, and disposition of output. The last is to become even more important with the proposed phasing out of the state's monopoly of purchases of key farm products (for example, grain, oilseeds, cotton) and the concurrent removal of stateset procurement prices and the contractual delivery quota. This decision has been taken in consequence of the upsurge in farm production and the resultant decline, in some cases, of market prices below state procurement prices. ${ }^{22}$

"A useful source is Frederick W. Crook, "The Baogan Daohu Incentive System: Translation and Analysis of a Model Contract," The China Quarterly, June 1985. pp. 291-303.
There can be no doubt that in agriculture there has taken place (since 1981) a considerable marketization of information and coordination through reasonably competitive market prices and direct lateral buyerseller transactions, and an equally impressive de facto privatization of property rights (involving greater flexibility of cropping patterns, work schedules, specialization, and marketing), both of which have affected motivation in a positive way.

\section{Results in Agriculture}

Proponents of going beyond adjustment naturally attribute the favorable situation in agriculture over the last several years to the contractual household netoutput delivery arrangement (baogan daohu). The results in agriculture are impressive (despite recent estimates of a fairly sizable reduction in grain output for 1985).. ${ }^{23}$ Production of grain, cotton, and other commodities has risen spectacularly, albeit from low levels. ${ }^{24}$ Yields have increased, and labor productivity has risen to the point where from 15 to 30 percent of the labor force has been released from land-related work. Per capita rural incomes have risen sharply.25

22 Du Runsheng, "Second Stage Rural'Reform," Beiling Review, June 24, 1985, pp. 15-17, 22; Zhao Ziyang. "Why Relax Agricultural Price Controls," ibid., Feb. 18, 1985, pp. 16-18, 29. "Starting this year [1985], Chinese farmers will no longer be obliged to sell a portion of their harvest to the state. Instead, they will depend primarily on contracts and the market demand to determine which crops they will grow. ... Through contracts with farmers, the government will purchase large amounts of grain and cotton at preferential prices and leave the rest of the crop to be regulated by the market. When the market price goes low, the state will purchase the grain or cotton from the farmers at a protective price higher than market price. On the other hand, when the market price goes high, the state may sell its reserves in big quantities to bring the price back down. By buying and selling the government can control the wide fluctuations in the market." See also "Market to Replace the Quota System." ibid., Jan. 14, 1985, p. 8. As part of the "second stage" (1985) agricultural changes, and reflecting the growing monetization and commercialization-specialization of the rural economy, the agricultural tax, formenty paid in grain, will henceforth be settled in cash in the "reverse ratio" of $3: 7$, i.e., 30 percent of the tax grain will be valued at the former state monopoly (quota) price, and 70 percent at the former (higher) above quota price. Xinhua (Beijing), May 24, 1985, in FBIS-CHI, May 29, 1985, pp. K/4-6.

${ }^{23}$ Estimates of grain production in 1985 put grain output at about 27 million tons below the 1984 record of 407 million tons. See John F. Burns، "Facing a Decline in its Grain Fields, China Retreats on Policy," The New York Times, Jan. 1, 1986.

${ }^{24}$ For example, grain production in China increased from 284.5 miltion metric tons in 1975 to 407.1 million metric tons in 1984. Statistical Yearbook of China 1983, op. cit. p. 158; and State Statistical Bureau, "Communiqué on Fulfillment of China's 1984 Economic and Social Development Plan," Beiling Review, Mar. 25, 1985, p. ii.

${ }^{25}$ According to Fei Xiaotong, "more than one-third of the total rural labor force in southern Jiangsu [Province] has given up farming " ("Surplus Rural Labor Put to Work," Beijing Review, May 27, 1985, p. 20). According to a New York Times report, "apart from peasants who have switched to growing cotton and other crops [rather than grain], about 50 million have cut back or abandoned farming to go into the fastest growing sector of the economy, rural industry." Such a comparatively low figure would constitute roughly 15 percent of the total agricultural labor force. See John F. Burns, "China Grain Crop Dips: Setback Seen for Policy," The New York Times, Dec. 23. (continued on p. 27) 


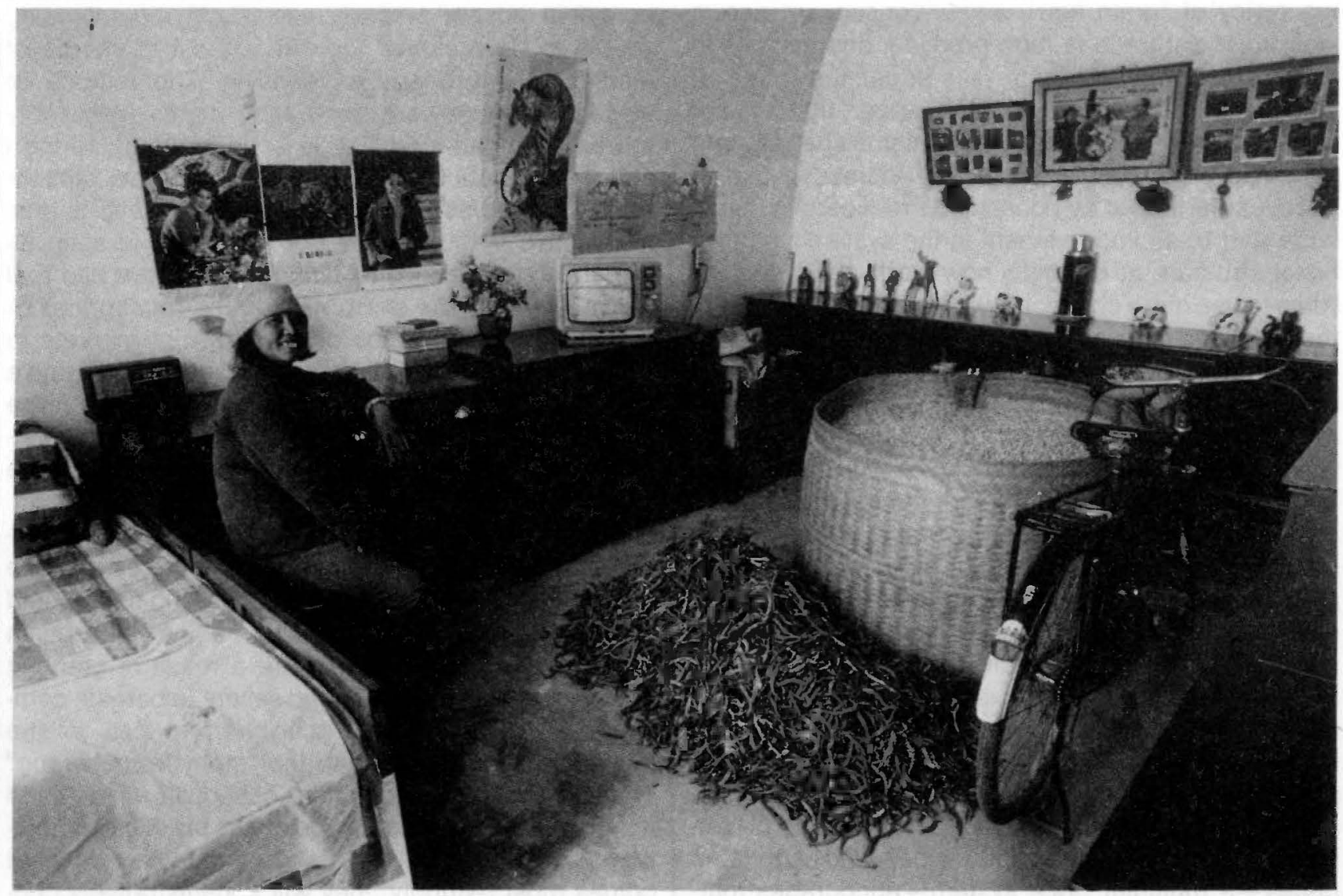

Jia Chunyan, a peasant of the once highly publicized model brigade of Dazhai, keeps her surplus from the 1984 corn crop in her living room together with her bicycle and TV.

-Sven.Erik Sjoberg, Pressens Bild from Photoreportersi

and household expenditure patterns have shown qualitative improvement. The marketed portion of agricultural output has been expanded, and town and village

1985. The Beijing China Daily (New York ed.) of Oct. 9, 1985, p. 4, puts the number of "surplus laborers" in China's countryside at 120 million, which is expected to reach some 230 million by the turn of the century. Sixty million surplus farm workers were employed in rural industries in 1985. There are indications that the rural industries are being developed too fast. There is also talk of "wasted funds, raw materials, and energy [which] greatly dampen the enthusiasm of the masses." Commentator's article Renmin Ribao, June 3, 1985, trans. in FBIS-CHI, June 7. 1985, p. K/9. See also Robert Delfs. "The Rural Uprising," Far Eastern Economic Review (Hong Kong), July 11, 1985, pp. 56-57.

Per capita income in 1984, according to a sample survey of peasant households, came to 355 yuan, an increase of 160 percent over 1978 , or 100 percent when price increases are taken into account. Beijing Review, Apr. 22, 1985, p. 16. A note of caution. Knotty statistical problems are involved in the sample surveys of peasant incomes. These include the questionable reliability of the price deflator in the countryside; the representativeness of the samples drawn on an unspecified but nonrandom basis; the question of collectively supplied consumption goods (not taken into account by the income data); and the propensity of local officials to "overfulfill" the statistical plan, i.e., the tendency to inflate statistics so as to show that what the leadership wants (that the peasants should grow rich) is, in fact, happening instantaneously. On the technical problems involved in rural income sampling, see Nicholas R. Lardy, "Consumption and Living Standards in China, 1978-83," The China Quarterly, Dec. 1984, pp. 851-52. industries (cooperative as well as private) have mushroomed, absorbing some of the farm labor that has been displaced.

There have also been a few troublesome results connected, it would seem, with baogan daohu (see discussion below). Nonetheless, there is no doubt that, so far at least, the positive developments in agriculture outweigh the negative ones. Most important, the problem of the deficient quality of economic performance in the agricultural sector has been addressed with remarkable success.

Two questions arise in this connection. The first concerns the source of the agricultural success story. Is it the partial decollectivization and movement away from central command planning represented by the baogan daohu? Or is it the contribution of other, lessreformist, more-technical factors? The latter include a succession of good weather years; increased use of chemical fertilizers; reversion to traditional cropping patterns (that is, the abandonment of the Maoist policy of commune and provincial self-sufficiency and of 
the policy of "grain first") and a consequent rise in interprovincial trade in farm produce; and the hike in procurement prices, which falls under the rubric of adjustment. It should be noted, however, that it is not easy to draw a line between institutional changes and technical ones. For example, the increased use of chemical fertilizers by household producers is due in large part to an improvement in the system's motivational structure; it is simply now worth the peasants' while to use more chemicals whereas it was not under the old workpoints system.

This leads to the second question: Is baogan daohu a reform or an adjustment? The answer is that it is an almost-reform. The degree of individual choice involved is far from minor. That choice is exercised to a large extent on the basis of market-price information; it is coordinated in large part by the market; and it is motivated by the lure of market gain. Property rights to assets-including land-are clearly and significantly privatized.

But the liberation of individual choice under the regime of baogan daohu is not nearly complete. Limitations on that choice are pervasive and significant as regards both state intervention in the market process and state restrictions on private rights of use of assets. The coexistence of market prices, "preferential" (quota and above-quota) prices, and negotiated prices - a multi-tier price system - encourages market manipulations and distortions, of which quality of produce is the first victim. But there is a more fundamental problem. Even though the Chinese peasant understands instinctively and fairly accurately the principles of the market mechanism and the rights in-

28 See, e.g., Chen Yun's speech to the National Party Conference (Sept. 23, 1985), in Beijing Review, Sept. 30, 1985, p. 19; and Tian Jiyun, vice-premier of the State Council, "Price System Due for Reform," ibid., Jan. 28, 1985, p. 19

${ }^{27}$ In early May 1985, the prices of 1,800 food items were partially deregulated in Beijing. Although the average price increase was said to have been 50 percent, beef prices went up 130 percent, and many vegetable prices doubled. Concerned about possible adverse reactions by urban workers to the price hikes, the government awarded every Beijing resident a subsidy equivalent (at present) to US\$2.19 a month. The total cost of this subsidy (about US $\$ 140$ million a year) is roughly equal to the subsidy formerly paid by the government on food purchased from peasants and resold to urban consumers at lower prices. In December 1985, Deputy Prime Minister Li Peng announced that this subsidy would be raised in order to "stablize" the situation in Beijing, and that there would be no major price changes in 1986. The New Vork Times, Dec. 23, and May 10, 1985; Ta Kung Pao (Hong Kong), May 31, 1985, in FB/S-CHI, May $31,1985, p$. W/1. A contingent of 11,000 government price inspectors was deployed in Beijing to prevent price gouging (some would say, to prevent prices from finding their market equilibrium leve). In 1984, a decision was made to partially deregulate the prices of certain raw materials and energy. This resulted in a sharp increase in factory production costs. The factories affected by the rise were not, however, permitted to pass on their increased costs in the form of increased prices of their products. Very few went out of business. The great majority were kept afloat by new government subsidies. The Wall Street Journal (New York), Apr. 1, 1985. herent in private property use, such understanding seems to have eluded the officials put in charge of markets and property supervision. The attitude of these officials toward fluctuating prices (especially upward fluctuation, which is seen as "profiteering") and market equilibrium prices in the context of commodity shortages ranges from unsympathetic to hostile. In this view, what is not controlled is seen as "arbitrary" and "blind." ${ }^{28}$ Such attitudes have had real consequences. The sharp rises in the retail prices of deregulated farm goods on China's city markets in 1985, for example, led to a flurry of administrative price controls, rollbacks, and subsidies. ${ }^{27}$ Even more dangerous, the theoretical grasp of how a marketprice system operates is still quite elementary on the part of many financial cadres. ${ }^{28}$

But it is not just a question of deficiency in theoretical comprehension of how market prices allocate resources. In practice, even for those who understand basic market principles, it is not easy to distinguish between price changes that are a result of granting greater freedom to buyers and sellers to bargain competitively and arrive at equilibrium prices in the market and price changes that stem from "wrong" sources such as speculation, cost-push, or demand inflation. Given the magnitude of this practical difficulty, the financial bureaucrats will most likely do what comes most naturally: they will administratively control prices.

Reform of the plan requires the mobility of factors of production. This is still not the case in China under baogan daohu. Even though factor mobility has increased compared with the post-1957 past, land and labor remain largely tied, and capital equipment (as well as crucial current inputs) must be purchased from the state monopolist. Although peasants are now permitted to leave the land in response to market signals, they are not permitted to leave the countryside

${ }^{26}$ Following are two examples of the cadres' deficient theoretical grasp of how a market price system operates. In Urumai, a meeting of cadres concluded that "commodity price departments must straighten out prices so as to conform to the law of prices. Prices which should be changed must be resolutely changed. Those which should be controlled must be strictly controlled. Prices which are not allowed to be raised, resolutely must not be allowed to be raised" (Xinjiang Regional Radio [Urumai]. May 30,1985 , trans. in FBIS-CHI, June 4, 1985, p. T/1). Consider also the statements of a Renmin Ribao commentator: "At present a small number of state commercial units in some cities and rural areas still show no interest in market conditions. Some of them are merely hankering after profits. When ore products are supplied, they force down the prices at the expense of the producers; and when products are in short supply or in great demand, they raise prices willfully at the expense of the consumers.

. The authorities concerned should strengthen effective management and supervision over the market and should strictly ban wilfull price hikes in violation of state regulations" ("State Commerce Should Learn to Participate in Market Reguiation," Renmin Ribao, May 28, 1985, trans, in FB/S-CHI, May 28, 1985. pp. K/15-16). Commentator would have flunked Economics 101 


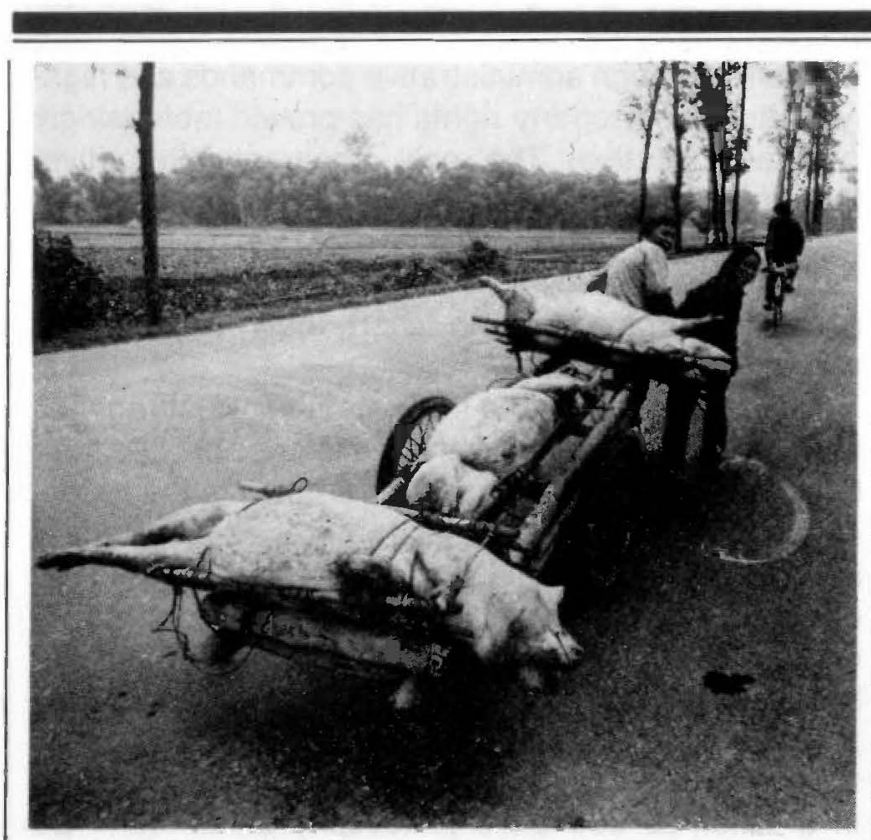

Privately raised pigs are carted to market by peasants near Chengdu in Sichuan Province.

-Lafiont/SYGMA.

(though many do). ${ }^{29}$ Thus, baogan daohu, despite its thrust toward free markets and privatization of property use and labor, is still only a half-reform, perhaps a little better than half. However, even the reformist half has so far operated in the broader context of the administrative command plan that still dominates the nonagricultural sectors of the economy.

\section{Industry: Some Problems}

Beginning in 1985, and lasting until 1990, this administrative command dominance over the nonagricultural economy (over "industry," or the "urban" sector for short) is to be relaxed and reduced in scope. The aim is to create a "planned commodity economy" in the urban sector, a code name for marketization and privatization. Reform-minded changes in industry are thus designed to bring the urban economy in harmony with the already accomplished reformist changes in agriculture.

${ }^{29}$ On the unauthorized and uncontrolled movement of rural labor to the cities, see Christine Wong, "The Second Phase of Economic Reform in China," Current History (Philadelphia), September 1985, p. 262. In the Chinese conception of the market, labor and natural resources (e.g., land) are not "commodities," hence they are not subject to market transactions that are concerned only with commodities. Capital goods produced by state firms are presently in a theoretical twilight zone. Some, like trucks and tractors, have been reclassified from noncommodities to commodities. See Robert $C$ Hsu, "Conceptions of the Market in Post-Mao China: An Interpretive Essay." Modern China (Beverly Hills), October 1985, pp. 438-40
Movement from adjustment toward reform in industry, however, is likely to prove more difficult than it did in agriculture. For one thing, whereas agriculture was a collective-sector economy, the industrial economy is primarily a state-sector economy. The state sector is characterized by a comparatively greater rigidity of administrative (ministerial-type) structures. Unlike the collective sector, it is the preserve of the bureaucrats who inhabit it in great numbers and benefit greatly from the privileges flowing from its administration. There is bound to be resistance to the expanded use of the market mechanism because it takes the bread out of the bureaucrats' mouths. Ironically, there is also likely to be considerable opposition to privatization of property rights from those who would seem to benefit most from such privatization - the enterprise managers, since most of them are neither professionally nor intellectually equipped to make the kind of property-related decisions and take the entrepreneurial risks required by market rules. Like their cousins in the countryside (the commune, brigade, and team officials), but on a more grandiose scale, these urban bureaucrats and enterprise managers are prone to react to the step-by-step relaxation of direct adminis: trative controls in a highly "feudalistic" and corrupt way that distorts and ultimately undermines the intent of the reform. Indeed, according to numerous reports in the Chinese press, a number of urban officials have taken advantage of commodity shortages, privileged administrative position and access to information, and the incompatible mix of administrative commands and emerging markets to line their own pockets. ${ }^{30}$

This has happened in China on a very impressive scale. Instead of market competition and useful output and innovation, what emerges is the old-fashioned bureaucratic squeeze, mutual back-scratching, parasitic payoffs, and bribes. One of the earliest reactions to the October 1984 decision and the consequent

so "When Party and government organs and cadres use their influence to set up enterprises ... all the profits are syphoned off into the pockets of individuals or small groups. ... These malpractices mar the reputation of the reform. . . They contaminate the organism of the Party. The new malpractices are all associated with money. Some cadres and Party members are . . blinded by lust for gain. . . They have become slaves to money" (Zhibu Shenghuo [Beijing]. No. 5, 1985, trans. in Inside China Mainland [Taipei], August 1985, pp. 15-17). See also Beijing Review, Apr. 1, 1985, p. 7. To date the biggest scandal, on Hainan Island, involved 690 parties who pocketed 2.1 million yuan (US\$720,000). Between January and March 1985, 872 more-or-less phoney companies were set up by 88 government departments and others (even schools and kindergartens). Contraband vehicles and 16 other luxury goods imported from Hong Kong and other capitalist places were resoid at hefty profits on the domestic market. See The Asian Wall Street Journat Weekly (Hong Kong), Aug. 19,1985, p. 6 . 
relaxation of central controls was the emergence of countless so-called briefcase companies set up by individual officials, groups of officials, and work units to take advantage of the fluid situation and to do business in the cracks between plan and market. It is important to point out that these "unhealthy tendencies," as they are officially called, are not manifestations of competitive market ethics that demand adherence to contractual law freely arrived at. Such tendencies are rather the expression of bureaucratic privilege let loose in a setting characterized by supply shortages, demand inflation, and a combination of highly im. perfect markets and administrative commands - the "commoditization" of long-standing malpractices. Instead of a market economy, what mushrooms in such a situation is "feudal socialism," that is, bureaucratic baronies operating in markets of various shades not only of impropriety and illegality, but of textbook market imperfection. ${ }^{31}$

The second reason why the movement toward reform in the urban sector will be more difficult than reform in agriculture is an extension of the first. In agriculture, the devolution of decision-making powers has been to the level of the private firm (the family). In the urban sector, this devolution will be made to the level of the lowest bureaucratic unit: the state enterprise, with all that this implies in bureaucratic bad habits and modes of behavior just discussed.

Then there is the practical matter of experience. Agriculture in China has during most periods operated partially in a framework of market prices (in village fairs) and de facto private property (household subsidiary plots). The private (family) property mentality promoted briefly by the agrarian reforms of the late 1940's and early 1950's has never been quite extinguished. Such has not been the experience of industry. Except for black-market prices, industry after the mid-1950's operated exclusively in a setting of state-set prices. All institutional manifestations of private property were eventually obliterated, first by the Great Leap Forward and then, more thoroughly, by the Cultural Revolution.

An important philosophical principle that has to be kept in mind when discussing adjustment and reform of the plan is that those in charge of the plan, the top leaders of the communist party, do not intend to relinquish control over the economy, but to make that control more efficient. Their goal in doing so is to facilitate maintaining political control. Direct control of the

\footnotetext{
"Barry Kramer, "Oriental Tradition-Chinese Officials Still Give Preference to Kin, Despite Peking Policies: Favoritism Stirs Resentment But Curb Isn't Enforced; A Job for a Son of Deng." The Wall Street Journal, Oct. 29, 1985.
}

economy through administrative commands and highly centralized property rights has proved increasingly counterproductive. The only apparent alternative, therefore, is decentralization with the help of markets and privatized rights of property. The big question thus is how to combine efficient central control with such decentralization - in short, how to create a decentralized monopoly.

It cannot be done, but most state socialist regimes in the last 30 years have given this impossibility their best shot. What is involved in this quest is the reconciliation of private and social interests. The market accomplishes such reconciliation by enabling the dominant influence of consumer demand to determine the volume and assortment of output and the basic configuration of income shares. This the philosophy of decentralized monopoly cannot allow. Reform of the plan, therefore, is caught from the start in a Catch-22 economic philosophy conundrum. Be this as it may, the Chinese leadership's decision to initiate changes in the urban economic structure clearly tries to address this problem by concentrating on two fundamental issues: macro-control and microautonomy.

\section{Macro-Control}

Macro-control concerns the relationship between the state (at whatever level) and firms or enterprises. Under the Stalinist model, practically all enterprises are socialized-nationalized or collectivized-and are directly controlled by the administrative command plan, which is also highly centralized. Under modified versions of this model, the role of administrative commands expressed in physical-technical norms (for example, output targets set in tons) is somewhat reduced, and the role of indicators expressed in financial terms (for example, output performance judged by profit and profitability rates, or by sales volume) is increased. At the same time, the financial indicators are less directive and more indicative than the physical-technical norms. There is thus a double transition: from physical to "value" 32 instruments of control, and from mandatory to more "guidance" planning (plus some free production and exchange on the periphery). However, the financial indicators ("economic levers") continue for the most part to be based

${ }^{32}$ As noted earlier, "value" instruments of control in a centrally planned economy are norms expressed in financial terms (e.g., profit, sales targeıs), the "values" being based on allocatively irrational, planner-determined prices. 
on state-set, cost-plus, allocatively irrational industrial prices. This double switch, therefore, does not advance the cause of economic efficiency by much, if at all, as can be demonstrated by examining the 30-yearold Soviet and East European experience with economic levers. From the standpoint of efficient resource use (which is the crux of the planned economy's problem), economic levers are only as good as the price system from which they stem. The Chinese are beginning to understand this, but their understanding is as yet imperfect.

In China, changes in the macro-control mechanism involve not only the double transition from physical to "value" instruments of control and from mandatory to guidance planning (which is in essence an adjustment), but also, since 1984, proposals for and some attempts at altering the industrial-price system vis-àvis the market mechanism. In the remainder of this section, I shall examine the key components of the Chinese planners' efforts to carry out this transition.

Planning. The idea is not to abolish mandatory planning but to reduce it, while at the same time increasing guidance planning. Reduction of mandatory planning in the Chinese case involves cutting from 120 to 30 the number of products regulated by the plan, and streamlining the number of administrative echelons involved in economic decision-making. ${ }^{33} \mathrm{~A}$ potentially important development is the distribution of some producer goods outside the state material-technical sup-

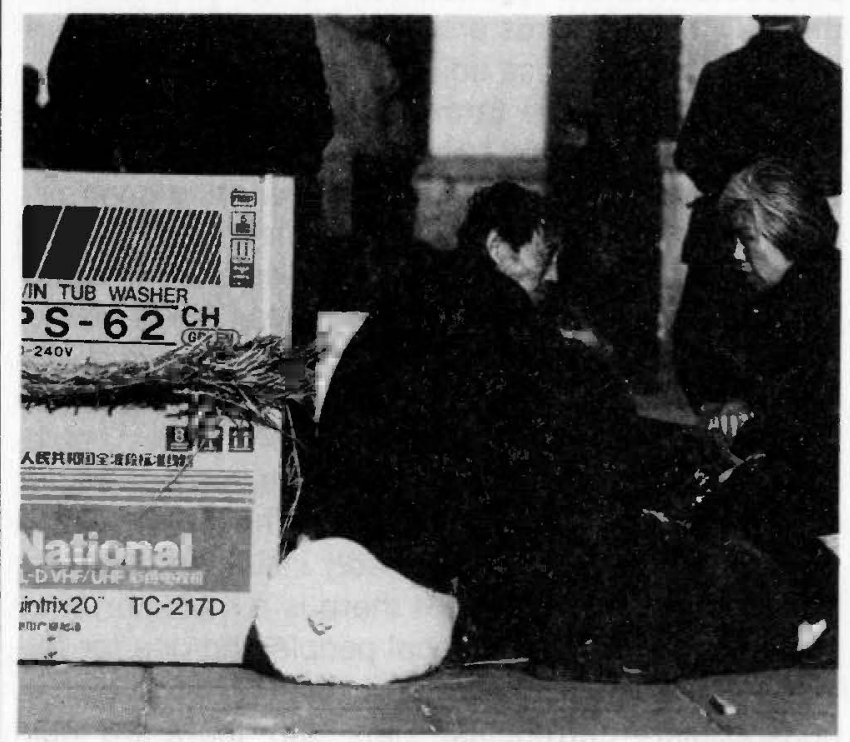

Rural Chinese wait at the Beijing railroad station on their way home with two of the "three bigs" - a television set and a washing machine. ply network, that is, outside the centralized system of producer-goods rationing. A primary mechanism for accomplishing this task is the holding of producergoods fairs, which have been reported from various places, most notably Shanghai. At these fairs, capital goods can be purchased and sold at prices negotiated by the buyer and seller within certain limits. This is a "Hungarian" development.

In Hungary, under the New Economic Mechanism, the Soviet-type material-technical supply system has been replaced by multiple-channel wholesale trade in the means of production. Increasing guidance planning, that is, the use of financially expressed incentives and disincentives, appears to involve primarily augmenting the economic role of lower level author. ities (provinces, municipalities, economic zones) compared with that of central authorities. Goods of minor or purely local importance are to be subject to the interplay of supply and demand forces in the market. The markets, however, are not to be completely free, but subject to various forms of supervision by local authorities.

There are two major problems with this arrangement as it has been adopted in China. First, mandatory planning, although reduced in terms of the number of commodities regulated, continues to apply to strategic products (for example, raw materials, steel) that enter into the manufacture of most other products. So long as mandatory planning is not completely abolished, it will, by its presence, however small, significantly limit and inhibit any and all reformist movements outside the area in which its writ runs. Second, there is reason to believe that shifting the responsibility for guidance planning from central to lower level bureaucrats will result in merely making guidance planning mandatory at the lower levels. There is evidence that mandating guidance at lower levels has, in fact, already happened. ${ }^{34}$ The short-term result of this propensity to dictate guidance has been

${ }^{33}$ Beijing Review, Oct. 29,1984, p. 7 , puts the reduction at from 120 to 60 . Some aggregation in the remaining balances of items that were listed separately before may be involved.

34 Abram Bergson, "A Visit to China's Economic Reforms," Comparative Economic Studies (Temple, AZ), Summer 1985, p. 76. A secretary of the Lingui County (Guanxi Province) Party Committee told bankers who were reluctant to lend money for building some questionable town and township enterprises: "We are not in charge of personnel administration, but your 'party tickets' are in our hands. . . You don't have to follow the leadership of the county government. . . Y You refuse to give heip. In the future don't call on us when you have problems." The bankers got the message and gave the Ioan. Renmin Ribao, June 5, 1985, trans.in FBIS-CHI, June 7, 1985, p. K/8. In the first six months of 1985, the Agricultural Bank lent 2 billion yuan to rural industries run by local authorities under guidance planning, a figure originally targeted for the whole year. Vigor Fung, "China Seeks to Slow Economy Without Reversing Reforms," The Asian Wall Street Journal Weekly, Aug. 19, 1985, p. 21 
an overheated economy with runaway investment and a further lowering of the quality of output. The situation is also unsatisfactory with respect to the local authorities' attitude toward the "free" market sphere. Indeed, according to reports in the Chinese press, it seems that local authorities have been wont either to turn the market into an underground operation benefiting relatives and associates in the bureaucratic power edifice or to restrict it in various ways. ${ }^{35}$

Price System. A largely unnoticed and unsung epic feat of bureaucratic futility occurred in the Soviet Union in 1967 when several million industrial wholesale prices were recalculated by hand and published in massive volumes as part of the USSR's proposed transition from mandatory-physical to guidance"value" planning. ${ }^{36}$ Although the new prices were updated and a little better calculated (in an accounting sense), they took little if any account of use values (demand). Thus, they were instantly obsolete. Like the old prices, they gave the wrong signals, and the waste went on.

Chinese policymakers today, unlike their Soviet counterparts in 1967, are aware of the need not merely to readjust the industrial price system, but to reform it, that is, to make such a price system a mathematical expression of competitive business transactions in a market in which the parties involved maintain wide rights of choice. Without such reform, guidance planning, even if carried out in the spirit of guidance rather than mandate, is a trivial pursuit from the point of view of allocative optimality. Intellectual understanding extends to the formidable difficulties - economic, political, psychological -inherent in freeing industrial prices. Caution and gradualness characterize the leadership's approach to the task of price reform ("We must grope for stones while crossing the river"). Unfortunately, by stretching out the price distortions

${ }_{35}^{3}$ Since deregulation, some local governments have refused to decontrol and have used their power to monopolize the timber trade and exploit forest farmers. Renmin Ribao, May 28, 1985, trans. in FBIS-CHI, June 3, 1985, pp. K/15-16. Local leaders have reportedly been restricting the marketizing changes promoted by the center by, for example, limiting the availability of open spaces and enclosed areas where market transactions are authorized, collecting unwarranted fees and fines ("squeeze'), suspending or confiscating business licenses, and capriciously occupying private business premises. Shandong Provincial Radio Service (Jonan), June 9, 1985, trans. in FBIS-CHI, June 11, 1985, pp. O/1-2. On the frequent verticality ("commandism") of what are supposed to be lateral, mutually arrived-at baogan daohu contracts, and the great number of levies and surtaxes imposed locally by cadres hostile to the baogan daohu system, see Ts'ai Ming-ch'in, "The Burden on the Peasantry: An Analysis of Mainland China's Rural Economy," Issues \& Studies (Taipei), April 1984, pp. 30-47.

${ }^{36}$ Gertrude E. Schroeder, "The 1966-67 Soviet industrial Price Reform: A Study in Complications," Soviet Studies (Glasgow), April 1969, pp. 462-77; and Jan S. Prybyla, "Soviet Economic Reforms in Industry," Weltwirtschaftliches Archiv (Kiel), Vol. 107, No. 2, 1971, pp. 272-316. over time, this pragmatic, step-by-step handling of change may itself undo the intent of reform. At the back of the policymakers' minds seems to be lodged the idea that a comprehensive freeing of industrial prices should await a significant increase in the supply of goods, that is, the advent of a buyers' market (as has happened with grain and some other farm products). However, the arrival of such a happy state may be obstructed by the present continued irrationalities of the shackled industrial price system.

So far, relative prices of some products have been readjusted and others will be readjusted later. Still, a lot of prices (e.g., for coal, steel, short-distance railway rates, housing rents, and public utilities) are "too low," while other prices are "too high." These readjustments of relative prices have several important constraints imposed on them. One is that the prices of products produced and distributed by the mandatory state plan should be left basically unchanged. What is meant by "basically" is not altogether clear, but it would appear that the prices of such products when "marketed by enterprises through their own channels according to specific regulations" are to be determined by market forces. ${ }^{37}$

An initial result has been the emergence of a dual price system for a number of key commodities (for example, coal, steel), which does nothing to make the price system allocatively more rational. The existence of the dual price system compromises economic calculation in monetary terms. Another constraint on price reform is the regime's commitment not to affect urban living standards adversely, not even temporarily. Thus, relative price adjustments and price deregulation (as with some farm products) have been typically accompanied by cash subsidies to urban wageearners or by the introduction of new price controls.

And so the present situation is marked by the not very compatible and distorting coexistence of stateset cost-plus prices, floating prices, white-market prices, and black-market prices. These various prices are supposed to be restricted to their respective spheres of mandatory planning (state prices), guidance planning (floating prices), and market sector (market prices), but they are not. They overlap and conflict. Not only is there a badly insulated three- (or four-) tier price system, but there is a multi-currency system as well: one for local people and one for foreigners (foreign-exchange certificates or foreignnonsocialist-currencies). Here, too, there are leak-

${ }_{37}$ "Tian Jiyun On Commodity Prices," Banyue Tan (Beijing), No. 9, May 10, 1985, trans. in FBIS-CHI, June 5,1985, p. $K / 12$. 
ages from one sphere to the other. Chinese renminbis mingle with foreign-exchange certificates, Hong Kong dollars, and US dollars, and there is a rampant black market in foreign currencies.

The debate continues. A question that has not been unequivocally answered is whether those who advocate fundamental changes in the industrial price system realize that price flexibility is not a one-time operation, that prices must be continuously flexible, that they must move spontaneously over time. But, as noted above, economic spontaneity is equated with arbitrariness and blindness, and political pluralism is seen as unhealthy bourgeois factionalism.

At present, worker mobility in industry, particularly in the state sector, is insignificant. With the exception of private-sector employment (which has risen substantially since 1978 but still constitutes a very small percentage -2.5 percent in 1984 - of total urban employment) and freer movement of labor among jobs in the cooperative sector, urban workers continue to be assigned to their danwei (work units) by labor bureaus, and both inter- and intra-enterprise labor mobility is subject to mandatory administrative planning. Although there have been some successful experiments in loosening up the mobility of scarce skilled labor, ${ }^{38}$ in general such efforts have met with theoretical incomprehension and bureaucratic opposition: there is need, it is said, to distinguish between "rational flow and anarchic free flow [that is, market allocation] of talented people." ${ }^{39}$ There have been numerous official announcements heralding future change: the Soviet-type eight-grade tariff wage system will soon be abolished in enterprises; ${ }^{40}$ enterprises will have more control over wage determination; ${ }^{41}$ wage rates will be determined more by individual workers' productivity-related criteria than by seniority; 42 and total payrolls will be allowed to fluctuate according to individual enterprise performance..$^{43}$

But such practices require the freeing of industrial labor so that it can move spontaneously in response

${ }^{38}$ For a discussion of some of the experiments, including the use of job markets for nation-wide placement, see Asiaweek (Hong Kong), Sept. 6, 1985, pp. 37-43.

30 Hunan Provincial Radio Service (Changsha), May 18, 1985, trans. in FBIS-CHI, May 21, 1985, p. P/3.

40 New Year's speech by Zhao Ziyang, premier of the State Council, to the National Committee of the Chinese People's Political Consultative Conference in Beijing, Jan. 1, 1985 , in Beijing Review, Jan. 7, 1985, p. 15

"Zhao Ziyang, "Report on the Work of the Government," delivered at the 2nd Session of the 6th National People's Congress on May 15, 1984, in Beijing Review, June 11, 1984, p. iv.

42 "Decision of the Central Committee of the Communist Party of China on Reform of the Economic Structure," Adopted by the 12th Central Committee of the Communist Party of China at its Third Plenary Session on Oct. 20, 1984, in Beifing Review, Oct. 29, 1984, p. xii.

43 See notes 40 and 41 to wage differentials; otherwise the changes are meaningless. The latter appears to be the case at this juncture, for the central authorities have made it patently clear that they will not abandon their control over wages altogether. (Even the "liberal" Hungarians have not done this.) The central government's interest in retaining a measure of wage control no doubt stems from its concern with the possibility of runaway consumption funds and inflation, as well as a concern about the skewing of the pattern of income distribution. ${ }^{44}$ Despite talk about the need, from an efficiency standpoint, to increase income differentials, in China such differentials cannot exceed certain rather narrowly defined limits without giving rise to serious political difficulties. Redistributive mechanisms (such as progressive income taxes linked to transfer payments) are not yet in place, so wage control has to be more direct. In other words, part of the problem with the price of labor, as with other prices, is the transitional incompatibility of the plan-market institutional arrangements of motivation, that is, the coexistence of administrative controls over labor mobility with not fully marketized incentive levers, with the two sets of instruments frequently working at crosspurposes.

Because the 1985 floating of wages by enterprises was to proceed from the payroll base figures for 1984 , enterprises hurried to raise wages (especially through the less easily controllable bonuses) before January 1, 1985.45 In December 1984, wages jumped an unprecedented 46 percent, most of the increase having been paid for by borrowing from state banks. That month, bank loans rose 48.4 percent, and government expenditures on payrolls went 70 percent over the budget. To foot the bill, the treasury printed 8 billion extra yuan in $1984 .{ }^{46}$

Interest rates, one of the economic levers on which the government has increasingly relied to guide the nonmandatory spheres of the economy, are not market-determined and have not proved effective so far in allocating capital funds rationally or in cooling down the overheated economy. Differentiated and floating

4" Zhao Ziyang, "Report on the Work of the Government," loc. cit. On the problem of runaway consumption and investment in late 1984 to mid-1985, see An Zhiwen,

"A Year in which Marked Progress Was Made in the Reform of the Economic Structure of the Cities," Renmin Ribao, May 13, 1985, trans. in FBIS-CHI, May 22, 1985 ,

pp. K/6-11, esp. p. K/10. Western economists estimate the 1985 inflation rate in the urban areas of China at 10 to 15 percent, with the Shanghai rate put at 17 percent. Leonard Silk, "China Hits Its Stride," The New York Times, Oct. 27, 1985.

45 Wong, loc. cit., p. 279.

4ong Kong Evening Standard, June 4, 1985, p. 8. In 1984, gross wages in Beijing rose 500 yuan. Of this, more than 80 million yuan was paid out in in-kind and money bonuses, including bonuses for worn-out shoes. Ming Pao (Hong Kong), May 17, 1985, p. 5 , in $F B I S-C H I$, May 22,1985 , p. W/3. 
interest rates are being tried, but any resemblance to market rates is coincidental.

\section{Micro-Autonomy}

Micro-autonomy means three things: experimentation with mixed public-private forms of property enfranchisement at the enterprise level; resort to partial or total foreign ownership of firms; and enlargement of the decision-making powers of state enterprises with regard to some or all of the following: production, supply, marketing, pricing, labor, and investment. To constitute meaningful reform (that is, to raise the quality of economic performance), micro-autonomy must occur within a setting of marketized macrocontrol. Otherwise micro-autonomy becomes merely an exercise in administrative decentralization - a tinkering with the bureaucratic apparatus. This has been the fate of micro-autonomy in the Soviet Union and most East European state socialist countries.

Mixed Property Forms. The coexistence of public and private forms of enfranchisement at the enterprise level is not new in the People's Republic of China. Mixed public-private enterprises existed in China before the mid-1950's, some of them even surviving until the Cultural Revolution in 1966. What is new is the direction and magnitude of change outlined in recent proposals. For example, under the proposed industrial changes, in the years 1985-87, all enterprises with fixed assets of less than 1.5 million yuan and annual profits of under 200,000 yuan are to be contracted out or leased to individuals or groups (cooperatives) for periods of up to five years. As in Hungary, such enterprises tend to be concentrated in the service trades, catering, maintenance, repair, construction, and local transportation. The arrangement is broadly similar to the baogan daohu system in agriculture, where, as will be recalled, legal social ownership is combined with broad privatization of the rights of use. The leased enterprises are required to pay rent and taxes to the state. They are granted relatively broad rights of business decision-making, including decisions about the distribution of the firms' net income. As an added benefit, public firms operating under the leasing arrangement will be allowed to avoid restrictions on the hiring of labor applicable to private-sector enterprises. ${ }^{47}$

It appears that most enterprises so far denationalized have been turned over to cooperative groups. The kind of small enterprises involved in this change currently account for a little more than half the total value of gross industrial output (a count that includes enterprises in rural towns and townships). It is expected that by 1987 most of that output value will be produced under the leasing cooperative arrangement.

It remains to be seen how this will work out in practice. As has been noted, the movement involves the de facto privatization of industrial property rights primarily to groups. The question is whether these groups will be bona fide cooperatives or neo-Stalinist collectives - which are simply a lowlier species of state enterprises. Much will depend on the taxing and rent-collecting attitudes and policies of local authorities and on whether there will be enough capital and current inputs outside the plan for the "autonomous" firms to do something with their newly acquired money. Will the leased firms compete with state firms for scarce materials, maybe even for custom? If so, what will be the state's reaction? Will the new arrangement further encourage an already active underground economy and contribute to the wellestablished propensity of officials to be corrupted?

In addition to the establishment of various forms of contracting and leasing arrangements, the legal private sector in urban areas has been significantly expanded. This trend, however, must be kept in perspective. Although the number of people employed in this sector (mostly in services, retail trade, and catering) has increased more than 15 -fold since 1978 , such workers still constitute only a very small proportion of total urban employment (2.5 percent at the end of 1984, compared with 3.2 percent in 1957 at the end of the Stalinist First Five-Year Plan). ${ }^{48}$ Even if one assumes considerable undercounting of this essentially amorphous backpack sector, legal private activities in urban areas are quite marginal and are likely to remain that way.

Foreign Ownership. There has been foreign equity participation in socialist development of communist states in the past - in the pre-Stalin Soviet Union during the 1920's, and since then in some other countries (for example, Hungary); the practice has the doctrinal sanction of no less an authority than Lenin himself. In China, since 1978 various forms of foreign participation have been encouraged. Two remarks have to be made in this regard. First, foreign industrial participa-

\footnotetext{
"Wong, loc. cit., p. 262, and Christine Wong, "Ownership and Control in Chinese Industry: The Maoist Legacy and Prospects for the 1980s," in US Congress, Joint Economic Committee, China in the 1980s, Washington, DC, US Government Printing Office, 1985.

4 Statistical Yearbook of China 1983, op. cit., p. 120; and Beijing Review, Mar. 25, 1985, p. viii.
} 
tion-whatever the precise form, and there are many - has as a rule been isolated from the rest of the economy either through special regulations or outright zoning. Second, the high hopes that such an arrangement would attract advanced technology and generate hard-currency exports (especially with respect to the Special Economic Zones) have not yet been realized. Actual (as distinct from contemplated) foreign investment in joint ventures of all kinds has been relatively modest, made largely by "Hong Kong compatriots" for tourism-related projects, industrial assembly work (e.g., assembly of television sets), and real-estate speculation (and perhaps for political insurance as well).

State Enterprises. The enlargement of the hitherto minimal decision-making prerogatives of state-owned enterprises is also a form, albeit more limited, of denationalization and privatization of collective property rights (including, prominently, greater rights by an enterprise to its profits). Collective firms, while disad- vantaged in many respects, have typically enjoyed greater independence from planning indices and ministerial intervention than state firms have. Such an increase in state enterprise "autonomy" is the micro end of the macro use of economic levers.

At the heart of the enterprise autonomy scheme is the question of profit retention. ${ }^{49}$ In the past, state enterprises remitted almost all their profits to the state treasury. The state then allocated nonreturnable grants for the enterprises' capital needs out of the state budget, and sent detailed instructions for the use of these funds. Under the new policy, however, instead of remitting all profits, enterprises will pay a tax on profits. This and other taxes will be used by the state as an economic lever to induce the desired enterprise behavior with respect to the after-tax profits retained by the enterprises. The self-interest of the

49 Barry Naughton, "False Starts and Second Wind: Financial Reform in China's Industrial System," in Elizabeth J. Perry and Christine Wong, Eds., The Political Economy of Reform in Post.Mao China, Cambridge, Harvard University Press, 1985.

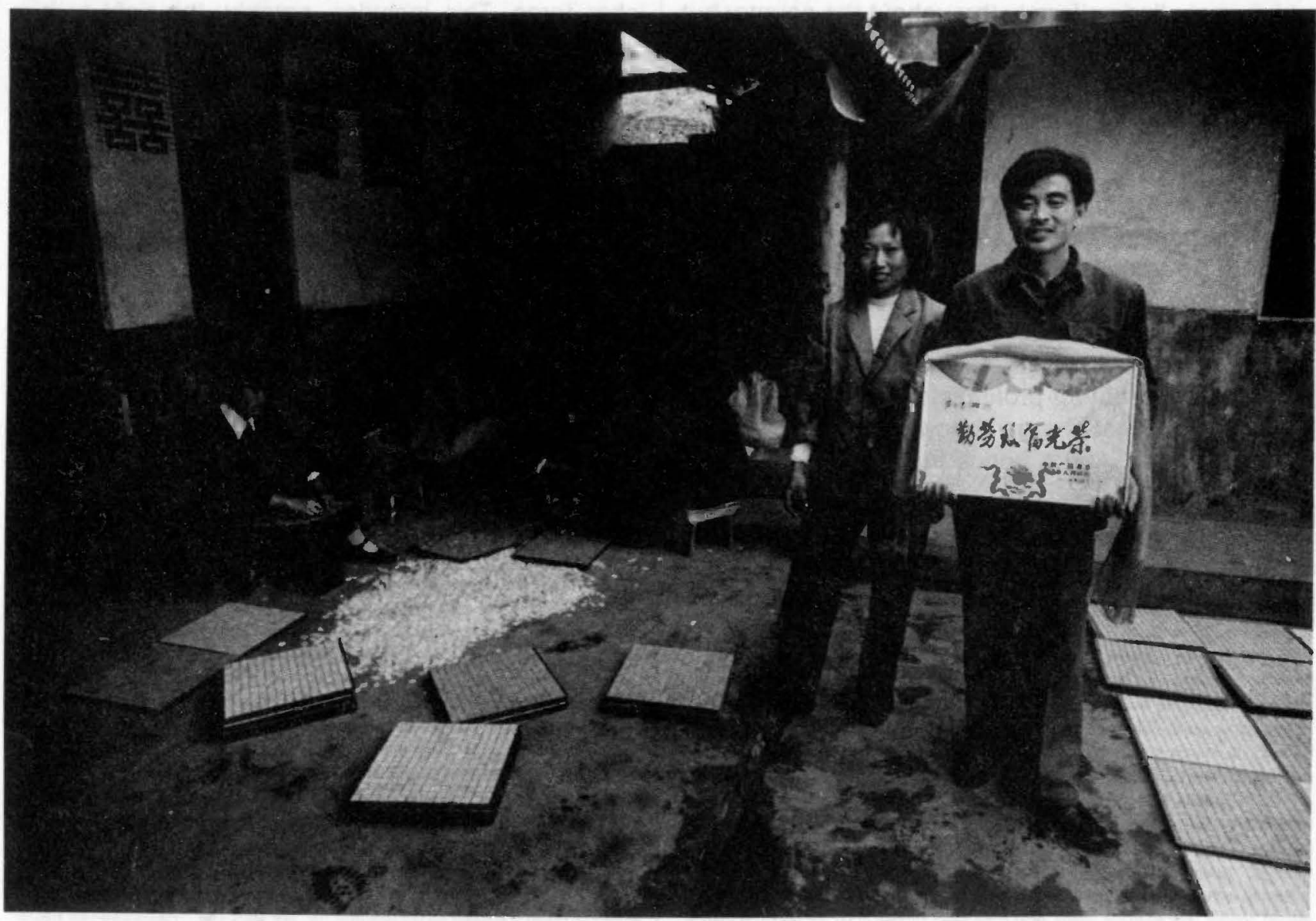

A peasant entrepreneur in Xiwei manufactures ceramic mosaics. 
enterprise, it is now believed, can be reconciled with the country's "social" interest (as perceived by the state) through the state's taxation policy. But such a view may be overly optimistic. The Soviet experience with profit retention shows that this assumption is correct only if the price system within which profit arises and taxes are deployed is market rational. ${ }^{50}$ Without a revolutionary marketization, that is, a freeing and debureaucratization of the industrial price system, the partial privatization of property rights in the form of profits to the level of the state firm remains an adjustment that will, in my opinion, keep generating allocatively wrong signais. Indeed, Soviet experimentation with tax-for-profit formulas (and the associated "enterprise funds") ${ }^{51}$ has now been going on for 30 years, and there are no indications that it has been at all helpful. In fact, there has probably even been some net regression.

Knowing this, the Chinese have introduced an array of corrective taxes to compensate for profit distortions due to the continued presence of an irrational price system. Among these taxes is a product tax, which is applied uniformly throughout the country but differentiated among products. The purpose of the tax is to confiscate that part of (windfall) profits on certain goods that arises from "wrong" pricing, as, for example, the profits on some consumer durables and cigarettes. ${ }^{52}$ There is also a resource tax designed to eliminate rent differentials among extractive industries and mining, and an adjustment tax whose purpose is to remove differences among enterprises in the same industrial branch, whenever such differences arise from "undeserved" causes. ${ }^{53}$ Moreover, to remind enterprise managements that capital is not free and to correct for profit distortions due to capital intensity, a capital charge is now levied on fixed and working capital. And a bonus tax is in force to help

so Alec Nove, The Soviet Economic System, 2nd ed., Boston and London, George Allen \& Unwin, 1980; Marshall I. Goldman, USSR in Crisis: The Failure of an Economic System, New York, W.W. Norton, 1983; and Prybyla, Market and Plan Under Socialism. "S1 See William G. Rosenberg, "Observations on the Soviet Incentive System," The ACES Bulletin (Bloomington, IN), Fall-Winter 1977, pp. 27-43; and Prybyla, "Soviet Economic Reforms in Industry." After-tax profits of Soviet state enterprises are allocated, in accordance with centrally determined formulas, among three major enterprise funds (also known as "economic stimulation funds"): the material incentive fund; fund for social-cultural measures; and production development fund. Monies from these funds may be disbursed by enterprises (with the approval of their supervisory ministries) for varlous enterprise-related purposes.

${ }^{32}$ On the various types of new taxes, see Wong, "The Second Phase of Economic Reform in China"; and Naughton, loc. cit. On broader issues involved in the change, see Nina P. Haipern, "China's Industrial Economic Reforms: The Question of Strategy," Asian Survey (Berkeley), October 1985, pp. 998-1012.

s3 What is "undeserved" is sometimes difficult to define in the much-plan, somemarket context. For example, many local firms have jumped in on the booming market in herbal medicines and cigarettes, allegedly reaping windfall profits from these addictions, while supplying inferior products. curb the "blind" and "wanton" disbursement of premiums. The use of taxes, including the most important, the eight-grade progressive income tax, ${ }^{54}$ shows that Chinese planners have a far better theoretical grasp of the issues involved in using economic levers with noneconomic prices than the Soviets have ever been able to manage.

But there still are many unresolved questions. The most important of these is who will do the determining of what is "reasonable" profit and what is not, and what criteria will be used to make that determination. When prices are allocatively distorted, it is not easy, even with the purest of intentions, to pinpoint what part of profits or profitability rates is due to erroneous economic calculation and what is due to other factors. In such conditions, there is bound to be considerable administrative fiat in the decision to tax, which may compound rather than lessen the problem. The Hungarians are familiar with this dilemma.

In addition to the right to a portion of profit and greater latitude in the use of retained profit, enterprises are to gain new rights with respect to their labor force. This includes, notably, the right to hire and to dismiss workers for cause, and the right to determine wages in relation to performance..$^{55}$ These rights, too, especially the latter, will almost certainly be circumscribed by the state's taxing policy and bureaucratic suasion. Other important rights granted to enterprises include the right to enter into lateral transactions with other firms, not as a general rule, but supplementary to the (guidance) plan, and on a larger scale and with less administrative fuss than was possible under the mandatory plan; the right to increase the scope of production outside the plan and of "self-disposal" goods; and the right to purchase certain producer goods and materials on a more or less open market. ${ }^{56}$

It is interesting but not surprising to note that the introduction of the tax-for-profits scheme has right away

${ }^{54}$ This is a graduated progressive tax that had long been imposed on collective enterprises and is now extended to state enterprises.

ss See notes 40 and 41 . Under the former system, enterprise managers-who were appointed by superior administrative-party authorities - had very limited rights with respect to the hiring and dismissal of workers in their enterprises. In conformity with the socialist ethical principle of job security (see note 9 above), it became almost impossible to fire incompetent (much less, superfluous) state-sector workers. The phenomenon goes by the name of the unbreakable "iron rice bowl." In Kaifeng, Henan Province, for example, of 400 large factories, 110 were at one point operating below capacity or had ceased operations altogether, while keeping everyone on the payroll. Beijing Review, May 25, 1979, p. 8.

${ }^{56}$ These various rights are listed in Beijing Review, June 18, 1984, pp. 10-11, in a report on the May 10, 1984, "State Council Provisional Regulations on Greater Decision-Making Powers of State-Owned Industrial Enterprises." For some recently aired innovative proposals on micro-autonomy, see Mary Lee. "Prescription for Health: Reform Highlights Management Problems in China," Far Eastern Economic Review, Sept. 12, 1985, p. 103. 
given rise to complaints in the Chinese press about large-scale tax avoidance and evasion..$^{57}$

\section{Prospects}

Instead of speculating on the future course of economic changes in China, I shall list some dangers that lurk along the reformist path. I assume that the current leadership, or an important and influential part of it, is committed to the improvement of the qualitative performance of the economy. I further assume that such improvement requires reform of the economic system rather than adjustment. In the Chinese context, as noted throughout this essay, this means that markets and privatized property rights would have to become dominant in the system. This would require the marketization of the plan's institutions of information, coordination, and motivation (in short, the establishment of competitive market relations among buyers and sellers), and the de facto privatization of property rights in the means of production, exchange, and distribution.

There are, I think, three interacting and interrelated groups of dangers in the way of the reformist movement in China. The components of these three groups have been active elsewhere in the world of the plan. They have succeeded in all instances in bringing the reform movement to a halt either early on (as in the Soviet Union) or a bit later (Hungary). The three groups are economic, political, and ideological.

The economic dangers come from three sources. First, from the nature of the market mechanism itself; second, from the basic incompatibility of market and administrative command institutions where these coexist because the reform is introduced incrementally rather than all at once; and third, from the behavior of those unacquainted with the operational rules and ethical requisites of the market and privatized property rights.

The market mechanism is very good at equilibrating supply and demand in individual product markets (and, incidentally, at resolving conflicts at a fairly "low" systemic level), but it is less good in achieving equilibrium on the macro level. This means that the in-

\footnotetext{
st In Hebei Province, between 1980 and 1984, some enterprises paid only 30 percent of the taxes due by them. Officials at various levels have been accused of "lowe ring tax rates at random, widening the range of tax exemptions, even regarding taxation as an obstacle to reform." Renmin Ribao, May 24, 1985, trans. in FBIS-CHI. May 28, 1985, p. K/10; Xinhua (Beijing), May 27, 1985, trans. in FB/S-CHI, May 31, 1985, p. K/2 See also, Marlowe Hood, "China Learns a Capitalist Lesson: Tax Evasion Goes With the Game," The Wall Streot Journal, Nov. 16, 1985
}

troduction of markets and privatized property rights might bring with it bouts of open unemployment, open inflation, booms and recessions, balance of payments disequilibria, and wide differentials in the distribution of income and wealth. This has happened in China. These problems are also present in the system of central administrative command planning, but most of the time they manifest themselves there in a suppressed or disguised form. Their openness in a market setting provides opponents of reform with excellent issues around which to mobilize resistance to the marketization and privatization process. This has been the case in Hungary.

The incompatibility of market and plan institutions during the "transitional" period has been discussed here and elsewhere. ${ }^{58}$ The effects of the cure of a little bit of market and more than a bit of planning, with partly privatized and mostly socialized property rights, have in general proved worse than the disease. A good instance of this unhappy mix in China is the attempted extension of urban micro-autonomy in a system still dominated by an irrational industrial price system. This institutional working-at-odds has been instrumental in subverting the reformist movement (never very strong) in the USSR and most East European countries.

Operating within the market environment brings rewards to many. However, it is not an easy or restful task; nor is it one with which all are familiar or toward which everyone is temperamentally and professionally predisposed. Moreover, the market is governed by stringent rules of the game. Observance of contract terms and abstinence from all action in restraint of trade, for example, are among the rules of market conduct, and a predisposition for risk-taking (not gambling) is among the chief qualities of the market entrepreneur. But the qualities required of government bureaucrats and state enterprise managers in a plan setting are quite different from those of the market entrepreneur. Where the entrepreneur is bold and adventuresome, the bureaucrat is obedient and staid. Where the former seeks to maximize gain, the latter tries to minimize loss.

Thrust into a market environment, bureaucrats tend to behave not like capitalists, but like black marketeers, lining their pockets, stealing, and generally

\footnotetext{
sa E.g., Gertrude Schroeder, "The Soviet Economy on a Treadmill of 'Reforms,' " in US Congress Joint Economic Committee, Soviet Economy in a Time of Change, Washington, DC. US Government Printing Office, 1979, pp. 312-40; idem, "Soviet Economic 'Reform': More Steps on the Treadmill," in US Congress Joint Economic Committee, Soviet Economy in the 1980's: Problems and Prospects, Washington, DC, US Government Printing Office, 1982, Part I, pp. 65-88.
} 
acting not according to the rules of the market, but according to the street-smart, corrupt codes of the underground economy. Their behavior is partly connected with the high degree of imperfection found in markets created by something that is neither adjustment nor reform. Mostly, however, it is due to the incompatibility of (even modest) pluralism in the economic marketplace and continued monopoly of political power.

It should be added that bureaucrats and managers are not the only ones who experience difficulty operating in a market environment. There are other groups as well; the nonentrepreneurial peasants, for example. The market, after all, is not responsive to nonpecuniary considerations. Those unable to operate in it according to the rules, or those excluded from it, may add up to a sizable political constituency.

The political danger stems not only from this ill-fit of market and centralized planning, but also from other sources. The market is a labor-saving device in the sense that it generates, transmits, and analyzes information about what needs to be done in the system; coordinates the disparate pieces of information; and provides the requisite motivation to get the job done. The market does all this at a comparatively low transaction cost; there is no need for bureaucrats to do this work deliberately and manually. In other words, the market threatens the bureaucrats in their capacity as "producers"-planners, supervisors, enforcers, double-checkers, and so on. The market also endangers the consumer privileges of the bureaucratic elite. Under the regime of the market, what matters is money, not political privilege. Reform thus threatens the bureaucracy on both counts.

Ideological dangers to reform come from two doctrinal sources: Marxism and Leninism. From the standpoint of Marxism, there are two issues connected with economic reform. Clinging to Marxism are socialist ethical codes (developed mostly after Stalin's death) that include the right to employment (regarded as more important than the right of free speech), interpreted in the state sector as the right to a lifetime job (in China, the right has traditionally extended even to children of many state-sector employees). Other rights associated with the Marxist ethos are access to basic necessities of life at low (subsidized) prices, "equality," stability, and others. ${ }^{59}$

The quest for market efficiency inevitably comes in conflict with these ethical desiderata and suscitates resistance in the adversely affected quarters. The codes are part of an implicit social contract between the monoparty state and the citizenry. The citizens receive these economic guarantees but at a sacrifice: they lack locational mobility, experience chronic shortages of desired goods and services, put up with low quality of products and other consumer frustrations, and accept a slow increase in their standard of living. Economic reform, with its competition, highrisk quotient, and short response time to rapidly changing market conditions, breaks that contract. Some firms have to close, some people have to be dismissed from their jobs, rents rise, and so on.

The second issue connected with Marxism and affected by economic reform is that of social classes. Marketization and de facto privatization of the economic system benefit not one class but many, and these are not the ones chosen as "progressive" by Marx's Laws of History. Although in the long run, reform benefits the urban proletariat - in fact, transforms it into a middle class - the short- and mediumterm benefits, and some of the longer term ones as well, accrue primarily to the entrepreneurial and independent segments of urban and rural society: the "rich" peasant, the shopkeeper, the enterprising businessman, the broker, and the venture capitalist. Reform changes not only the output structure of the economy but its class structure as well, and in the process redefines class in a non-Marxist sense.

If Marxism is associated with the socialist ethical code, Leninism is identified-much more accurately - with party control over all spheres of life. Marketization and privatization reforms diffuse economic power among many centers; production, exchange, and distribution relations tend to function best when horizontally integrated rather than vertically, and tend to diversify and be made more indicative and indirect-all of which goes against the Leninist imperative of absolute power absolutely concentrated. On this Leninist issue of control, economics, politics, and ideology converge. Marketization and privatization, the opponents of reform argue, cause not only macroeconomic woes and aberrant behavior ("spiritual polIution"). They threaten the planning, supervisory, and managerial elites both as "producers" and consumers; they are ethically repugnant on a Marxist interpretation; and, above all, they are a menace to unified monopolistic control by the Leninist party.

These are serious counts that have to be carefully considered in arriving at a perception of the odds for and against the reformist movement in China.

${ }^{58}$ See footnote 9. 


\title{
Gorbachëv and Eastern Europe
}

\author{
Vladimir V. Kusin
}

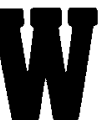

hen Mikhail Gorbachëv became Soviet party leader in March 1985, most Western observers anticipated that he would provide a more imaginative and dynamic guidance for Eastern Europe than his immediate predecessors had exercised. At the same time, observers were divided as to whether this imagination and dynamism would translate into greater uniformity in Eastern Europe or whether Gorbachëv would allow the individual states greater latitude. The official proclamation of Gorbachëv's accession was cast in a continuity mold, promising that Moscow would go on "doing everything possible and necessary to strengthen the socialist community." By contrast, Gorbachëv's maiden speech as leader (at a Central Committee meeting) and a Pravda editorial two days later contained turns of phrase that raised the expectations of those desiring reformist change. Instead of advocating "strengthening the might of the socialist community," the Gen+ eral Secretary pledged "fraternal friendship" with it. Missing also were such ritual catchwords as "socialist internationalism," "cohesion," and even "MarxismLeninism," not to mention the once obligatory commit-

' TASS in English, Mar. 11, 1985, in Foreign Broadcast Information Service, Daily Report: Soviet Union (Washington, DC-hereafter, FBIS-SOV, Mar. 11, 1985. pp. $R / 2-4$

Vladimir V. Kusin is Deputy Director of Research and Analysis, Radio Free Europe (Munich). Formerly associated with the universities of Lancaster, Glasgow, and Hokkaido, he is the author of The Intellectual Origins of the Prague Spring (1971), Political Grouping in the Czechoslovak Reform Movement (1972), and From Dubček to Charter 77 (1978), and numerous articles on Eastern Europe. ment to increasing the bloc's "defensive capacity." Yet, in his March 13 funeral oration for Konstantin Chernenko delivered from atop the Lenin mausoleum, Gorbachëv revived some of the old stereotypes:

Faithful to the principles of socialist internationalism, our party will continue to do everything for broader interaction between the fraternal countries and for the enhancement of their position in international affairs. ${ }^{3}$

On the same day, the new Soviet leader met briefly with bloc leaders in Moscow for the Chernenko funeral. According to private East European sources, a cool and detached Gorbachëv simply told his lesser comrades to get on with the business at hand with greater application and consistency. Henceforth, he indicated, the emphasis would be on economic efficiency and tighter coordination of the bloc's external actions. All should strive for a lessening of tensions vis-à-vis the West, but only on the basis of bloc unity directed by Moscow. A Warsaw Pact summit would be held in due time to extend the treaty. Hungary's János Kádár reportedly sought to pose as the bloc's elder statesman paternally accepting Gorbachëv into the family, but the General Secretary remained aloof, gently referring the Hungarian to his proper station by indicating that he would not attend the Hungarian party congress, then only two weeks away. ${ }^{4}$

\footnotetext{
${ }^{2}$ For Gorbacherv's March 11 speech, see Pravda (Moscow), Mar, 12, 1985; for the editorial, ibid., Mar. 13, 1985.

TASS in English, Mar. 13, 1985, in FBIS-SOV, Mar. 13, 1985, pp. R/2-3.

4 The communiqué from this encounter appeared in Pravda, Mar. 14, 1985. Western observers generally interpreted this meeting as an "informal" one. See, e.g. Le Monde (Paris), Mar. 14, 1985.

The only specific point apparently mentioned was the possibility (later dropped) that the 27th CPSU Congress might be brought forward in time-a sign that Gorbacherv may have overestimated his own capacity to break the back of opposition to him within (continued on p. 40)
} 
Although the Budapest event might have offered an opportunity for a more extensive summit, time was too short. Moreover, Gorbachëv had to be doubly careful with regard to Hungary. As the new leader of an empire in trouble, it would be imprudent to be seen either endorsing or condemning the somewhat unorthodox ways of comrades in one of the constituent countries so early in his tenure. Even if he himself had wanted to give his blessing to market-based reformism, which - despite considerable conjecture - is by no means certain, his own party's Politburo, given its composition at Gorbachëv's accession, would most likely not have allowed him to do so. Also, once he took a stand, lesser bloc leaders would have felt obliged either to follow suit or raise objections. The caucus could have degenerated into a squabble. Rather than show himself too friendly with Kádár, Gorbachëv needed to demonstrate that East Europeans were a priority with the new Soviet chief, but only as a collective entity.

By and large, the Western press saw Gorbachëv's accession as a blessing for the Soviet Union's European allies. The Los Angeles Times ran the headline "Gorbachëv May Be Eastern Europe's Best Hope for Evolution." The London Times correspondent in Warsaw, in a piece entitled "Time Ripe for a Strong Hand," reported that "in Poland one senses the desire for the emergence of a strong, reform-orientated, non-interventionist leader in the Kremlin." ${ }^{\circ}$ The Washington Post stressed the economic angle: "Soviet Allies Optimistic on Modernization." "The International Hera/d Tribune proclaimed that "East Europe Sees Gorbachev as Sign Uncertainty Is Over," in Le Soir bore the title "In the East, a Breath of Fresh Air."

Many observers further believed that some bloc countries might fare better under Gorbachëv than would others. The Hungarians might have their departure from orthodoxy sanctioned. The East Germans might recover the leeway in dealing with Bonn they had lost in the late summer of 1984. Poland's Wojciech Jaruzelski might be given a go-ahead for

the Soviet party. Gorbachèv reportedly asked East European party leaders how preparations were going for their party congresses and whether the gatherings might be held earlier (this only related to the Bulgarian, Czechoslovakian, East German, and Polish comrades, since the Hungarian congress was imminent and the Romanian congress had been held in November 1984)

${ }^{5}$ Robert Gillette, Mar. 12, 1985. Attribution of headlines to correspondents can, of course, be misleading, but in the cases cited, the home-base editors did read their man in the field fairly accurately.

- Roger Boyse, Mar. 12, 1985.

'Bradley Graham, Mar. 13, 1985.

a Henry Tanner, Mar. 13, 1985

Pol Mathil, Mar. 14, 1985 conciliation with his discontented populace. On the other hand, the Romanians might be brought to heel. The Bulgarians might be chastised for economic failures and for botching up their involvement in the papal assassination attempt and for the handling of their Turkish minority. The Czechoslovaks, too, might be unceremoniously impelled to mend their efficiency record and to start a reform. Leadership changes in Czechoslovakia, Romania, and Bulgaria, some believed, might be speeded up. In general, languishing in economic and political doldrums would no longer be allowed.

What really came to pass did not quite match expectations, but neither did it depart drastically from the predictions. Let us review the record nearly a year later, looking first at issues of bloc-wide significance and then at the specifics of Moscow's bilateral dealings with the East European states.

\section{Renewing the Pact}

There was never any doubt that the Warsaw Pact would be renewed after its first 30 years, but the precise form of renewal and the nature of Pact obligations did evoke some debate among the member states. It is known that Romania-and possibly others - wanted the Pact extended by only five or 10 years rather than by 20 years with an automatic 10-year further extension. Ceauşescu later said that he had favored setting a shorter treaty duration as an act of goodwill toward the West, "to give a new perspective to the peoples, to the struggle for the abolition of military blocs and for peace." In the end, he signed the 20-plus-10 extension "to consolidate collaboration and friendship with the socialist countries," but the Romanian leader added that he hoped the treaty would not have to run its full course and that it would be terminated earlier, "concomitantly with NATO." 10 Judging from the perfunctory nature of the April 26 renewal ceremonies in Warsaw and other indirect evidence, 11 the issue had been resolved earlier in the month.

${ }^{10}$ See excerpts from his speech before the Romanian State Council, as reported by Agerpres in English at 1732 GMT, May 22, 1985, in Foreign Broadcast Information Service, Daily Report: Eastern Europe (Washington, DC-hereafter, FBIS-EEU), May 23, 1985, p.p. H/1-2.

Actually, the Romanian proposal was probably not a major bone of contention. The Washington Post of Apr. 2, 1985, quotes an unnamed Western diplomat in Bucharest to the effect that the Romanians had "glamorized and promoted their own part in the renewal . . to reinforce their image with the West as the Warsaw Pact's difficult member." The diplomat thought that "there never was any real intention [by Ceauşescu] not to renew or not to go along with Soviet terms." 


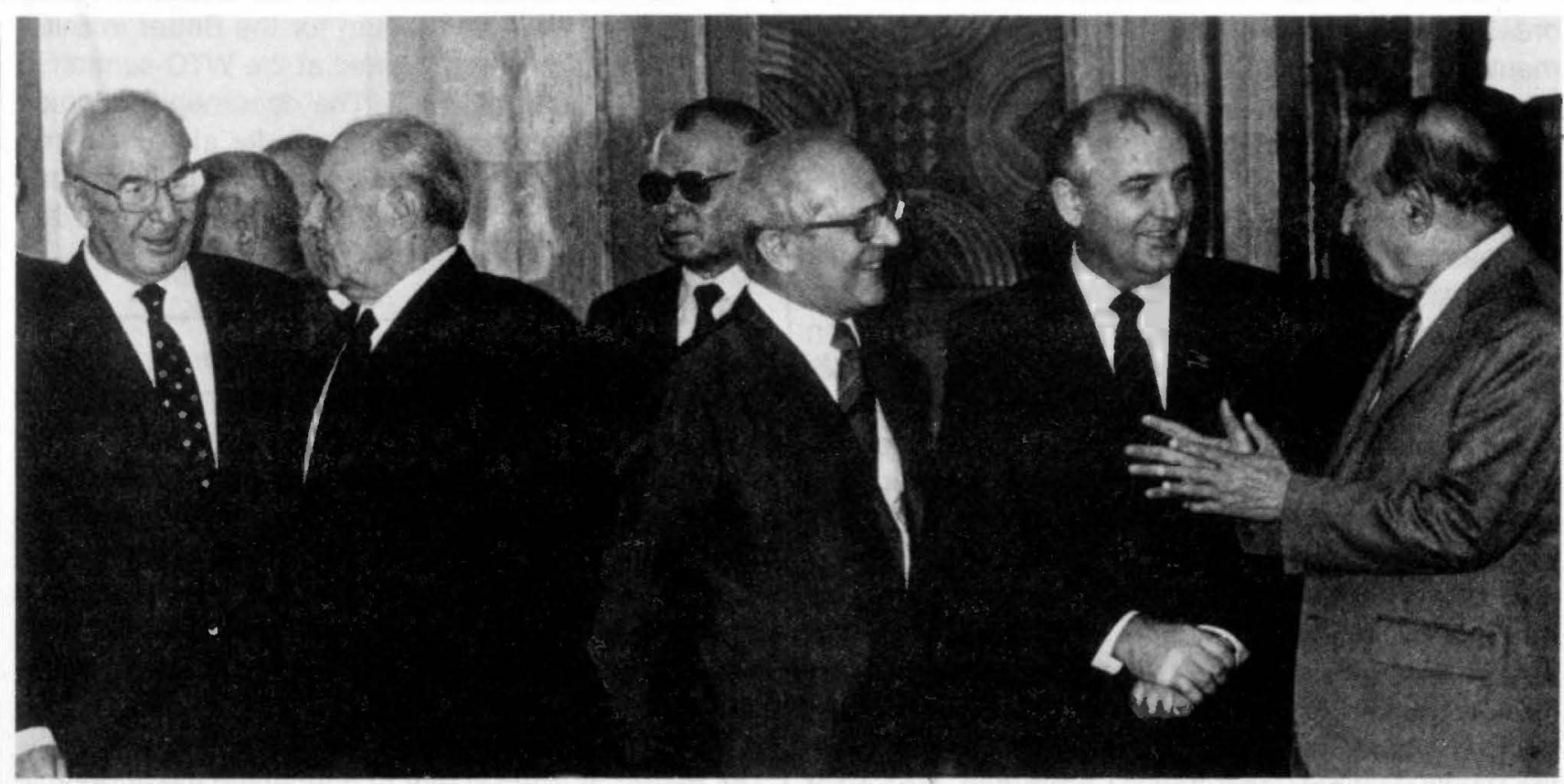

At the October 1985 meeting of Warsaw Pact leaders in Sofia: from left to right, Gustav Husák, János Kádár, Erich Honecker, Mikhail Gorbachëv, and host Todor Zhivkov.

Defense funding has been another sore point. A commentator speaking on Budapest Radio on the day of the Pact's renewal argued against relying on linear growth in armaments as the linchpin of military modernization. He called for more "rational" ways of improving combat capabilities. ${ }^{12}$ Three weeks later, two Hungarian military leaders went on record in separate releases with an assurance that their country would meet its obligations under the Pact, but only "in proportion to the capabilities of our national economy and our realistic possibilities." One of them added that "the principle of a proportionate distribution of the burden" had been expressly laid down during the renewal negotiations. ${ }^{13}$ In May, Ceauşescu declared publicly that Romania had not been increasing its military appropriations for the past two years and that the

In addition to signing the renewal document and an accompanying communiqué, the Pact leaders laid wreaths at three places and held a joint dinner before concluding the one-day affair. British newpaperman Ian Mather, interviewing Czechoslovak Foreign Ministry official Richard Dvorak in mid-April, was told regarding renewal of the Pact that there had been "some reservations, particularly from Romania, but they are now "settled." See The Observer (London), Apr. 14, 1985.

${ }^{12}$ Colonel Péter Déak. Radio Budapest, 6:30 p.m., Apr. 26, 1985, trans. by Radio Free Europe monitoring service (Munich).

${ }^{13}$ Deputy Prime Minister and then Defense Minister General Lájos Czinege, and Secretary of State in the Ministry of Defense General Lájos Morocz, in two separate releases by MTI (Hungarian Telegraph Agency, Budapest), in English, May 14, 1985. See also Vladimir Socor, "Warsaw Pact Summit Renews the Warsaw Treaty," Radio Free Europe (hereafter, RFE), Background Report (Munich), No. 53, June 19, 1985
Warsaw Pact countries should now unilaterally reduce their defense budgets by 10 to 15 percent annually "to make the NATO governments as well as others follow suit." 14

East Germany also had some reservations about its Pact obligations, if we are to judge from an unusual sentence in a communiqué issued in mid-May, at the end of CPSU Politburo member Viktor Grishin's visit to East Berlin. It read: "In the future, too, the GDR will do justice to its responsibility within the defense alliance of the Warsaw Treaty as a cornerstone of peace and socialism in Europe." 15

It would be wrong to see the pre-renewal tussle as simply a one-way street, with the allies hurling amendment requests at the USSR. On its part, the Soviet Union may have wished to make the Pact more political and more specific where the original text had been quite general. ${ }^{16}$ In the end, nothing was changed in the document, not even its preamble, with its open references to the situation as perceived by the Pact's

${ }^{14}$ See Agerpres, May 17, 1985, for Ceauşescu's interview on Spanish television; and FBIS-EEU, May 30, 1985, pp. H/1-5, for a translation of the text of his address to the Socialist Democracy and Unity Front on May 23, as published in Scinteia (Bucharest), May 24, 1985.

is ADN International Service in German, 1149 GMT, May 14, 1985, trans. in FB/S-EEU, May 15, 1985, p. E/1.

${ }^{16}$ This possibility is discussed in an excellent article by Regensburg University Professor Jens Hacker in Frankfurter Allgemeine Zeitung. Dec. 7, 1984. 
creators in the mid-1950's. The absence of amendments, in the direction of either reduced or increased central control in the Pact, may be seen as a compromise, the simplest option.

This compromise probably reflected the reality that, as a military organization, the Warsaw Pact per se does not play a major role in East-West strategic relations. The Czech ex-communist exile Zdeněk Mlynár had even suggested that the Soviet Union could perfectly well allow the Pact to expire in 1985, which would be applauded by members of peace movements and various statesmen in the West to Moscow's advantage. With or without the Pact, he argued, Eastern Europe would still remain a military bloc under Soviet command. " But, as Mlynár predicted, there was no dissolution. This is because the Pact's function as a legally defined political bond between the East European regimes and the USSR retains a definite value. By having to sign the joint political platforms promulgated periodically through the Pact's Political Consultative Committee, the Soviet Union's "allies" commit themselves to postures from which later deviation can be easily censured. ${ }^{18}$

The reality of Soviet domination in Pact affairs was highlighted at a December 4 meeting of bloc defense ministers in East Berlin, where Soviet Defense Minister Sergey Sokolov vowed that the Warsaw Treaty Organization (WTO) would match any US arms buildup. The fact that East Germany had the previous week pledged to increase its 1986 defense budget by 7.7 percent suggested that it was the WTO's East European members who would bear the brunt of expanded military outlays. ${ }^{19}$

The Pact summits are useful to Moscow not only for enforcing defense policies; they also can serve as platforms from which to launch political offensives. An example is the declaration "For the Elimination of

\footnotetext{
$"$ Interview in Die Weltwoche (Zurich), Apr. 11, 1985.

${ }^{18}$ The Political Consultative Committee (PCC) was defined in the original (and renewed) treaty as consisting of "members of government or some other specially appointed representatives." By 1960, the practice of holding PCC meetings as summits for party chiefs had become established. As of the end of 1985, there have been 23 PCC meetings, including the constituent session. Seven were held under Nikita Khrushchev, 11 under Leonid Brezhnev, one under Yuriy Andropov, and four so far under Gorbachev

19 The Washington Times, Dec. 5, 1985. For the East German announcement, see Neues Deutschland (East Berlin), Nov. 30, 1985. Poland astonishingly reported spending 31.7 percent more on defense in 1985 than in 1984. See Zolnierz Wolnosci (Warsaw), Nov. 27, 1985.

20 Pravda, Oct. 24, 1985, trans. in Current Digest of the Soviet Press

(Columbus, $\mathrm{OH}$-hereafter, CDSP), Nov. 20, 1985, pp. 4-5.

21 Pravda, June 27, 1985.

22 See the communiqué in Pravda, June 29, 1985.
}

the Nuclear Threat and a Turn for the Better in European and World Affairs" signed at the WTO summit in Sofia on October 23, 1985. The document endorses various Soviet proposals purportedly aimed at preventing an arms race in space, terminating the arms race on earth, and freezing Soviet and US military forces at current levels. ${ }^{20}$

\section{Economic Linkages in the Bloc}

As in the case of the WTO, so with the Council for Economic Mutual Assistance (CEMA) the USSR under Gorbachëv seems to be pursuing long-standing policies, but with increased vigor. In a speech delivered in Dnipropetrovsk on June 26 , at a time when the prime ministers of the member states were assembled in Warsaw at the 40th session of the CEMA Council, Gorbachëv stated:

The matter at issue is that of deepening the economic cooperation and economic integration of the member countries of the CEMA. Well-adjusted specialization and production cooperation, active interaction in advancing science and technology make both our community as a whole and each of its members more robust and still stronger in defense, and nullify the policy of economic pressure that is actively pursued by the West toward the socialist countries. ${ }^{21}$

These goals, confirmed by the CEMA Council at the conclusion of its June 25-27 session, ${ }^{22}$ have five interlinking components: close coordination of national five-year plans so as to dovetail production programs; conclusion of special long-term cooperative agreements, such as in extracting and transporting Soviet natural gas or conserving on energy consumption; elaboration of a joint plan of action for scientific and technical work; a continued high concentration of trading within the bloc, with special emphasis on the delivery of quality goods and consumer durables from Eastern Europe to the USSR; and limitation on trade and other economic links with the West. Although Hungary's economic experiment is apparently going to be allowed to proceed, the requirement to partake fully of CEMA's non-market-based integration limits the possibility for that country or other East European states to move further away from centrally determined economic parameters.

The June CEMA session also made a public gesture toward greater cooperation with the European Communities. However, Western officials generally concluded that the effort contained a high degree of 
propaganda and that bloc-to-bloc dealings would reinforce Moscow's central power over decisions on EastWest trade that ought to remain the preserve of individual East European countries. ${ }^{23}$

The prime ministers of the CEMA states (which include, in addition to the USSR and its East European allies, Cuba, Mongolia, and Vietnam) convened in Moscow in December to launch a 15-year cooperative program to upgrade their respective economies technologically. Five key areas were targeted for joint efforts: electronics, production automation, atomic energy, new industrial materials, and biotechnology (especially as applied to agriculture). ${ }^{24}$

Under Gorbachëv, the Soviet party is evidently seeking to increase the role of the bloc's communist parties in overseeing fulfiliment of CEMA commitments by their respective states. On May 20-21 in Moscow, secretaries of the respective national parties in charge of economic matters held the first of what are slated to be annual meetings. ${ }^{25}$ In the words of Czechoslovak delegate Miloš Jakeš,

the main purpose was . . to make use of CEMA experience in party work in order to mobilize the toiling masses for the fulfillment of a/l CEMA-set objectives. ${ }^{26}$

The key question is: Can CEMA integration work better under Gorbachëv than it did under his predecessors? It is now nearly 15 years since CEMA, meeting in Bucharest in July 1971, adopted a "comprehensive" program for bloc economic integration, and the organization still remains largely a vehicle whereby Soviet raw materials are exchanged for East European manufactures and investments. The price structure within the trading bloc is in a shambles, ${ }^{27}$ and growth rates of the member states' economies are generally declining. The Gorbachëv approach to

${ }^{23}$ On relations between CEMA and the Communities and on other CEMA issues of the 1980's, see Vladimir Sobell, RFE, Background Report, Nos. 8,63, and 67, of Feb. 4, July 2 , and July 17, 1985.

24 The bloc also formed a six-nation organization, Interrobot, to coordinate production of industrial robots. See account in The Washington Post, Dec. 19, 1985.

${ }^{25}$ Pravda, May 22, 1985.

${ }^{26}$ Rudé Právo (Prague), May 22, 1985. The new measure was also discussed in an article "Internationalism in Practice" appearing in Pravoa, June 15, 1985, obviously designed as a guideline for the upcoming CEMA summit.

${ }^{27}$ Neve Zürcher Zeitung, of June 29, 1985, reported that Soviet Premier Nikolay Tikhonov abruptly closed a price debate at the Warsaw CEMA meeting when some East Europeans began to talk about the unevenness of the price levels in raw materials, machinery, and food.

The Soviets even launched a counter-offensive on the price issue. In September in an article specially written for the Czechoslovak party daily, then USSR Gosplan Chairman Nikolay Baybakov stated: "The price level is of considerable importance for the intensification of trade in engineering goods. In our opinion, there is a certain discrepancy between the quality of various items delivered to the USSR and their prices." See Rudé Právo, Sept. 6, 1985.
CEMA seems to be the same as his approach to the domestic Soviet economy: tighten discipline now and perhaps institute reform later. One wonders whether the sheer weight of the predicament and the resistance of established institutions and processes will not force him to keep postponing reform in both settings.

\section{Internationalism vs. Nationalism}

Although Moscow doubtless would prefer unquestioning, unvarying obedience on the part of its East European partners, reality - as the discussion of WTO and CEMA developments has already suggested - is something different. The response of alliance partners to Moscow's lead has varied considerably, and the Soviet Union itself has shown some flexibility in dealing with its allies.

A June 15, 1985, Pravda item entitled "Internationalism in Practice" sternly asserted that the national interests of CEMA member countries must be "correctly conjoined" with the international interests of the bloc as a whole. Communists, it was maintained, must "always and in everything" remain loyal to Marxism-Leninism and proletarian internationalism. This was followed by an equally stern and far more specific article in the June 21 Pravda over the pseudonymous byline of $O$. Vladimirov. ${ }^{28}$ Vladimirov condemned a number of sins, without attributing them to any one country: overestimation of the role of private property in a socialist economy; undue emphasis both on national attributes and on the imitation of foreign models; disrespect for the basic common principles of socialism; "revisionism" regarding the national issue, and exacerbation of minority problems; spreading of "national communism"; unprincipled compromises with antisocialist forces; the claim that small countries can mediate between the great powers; Russophobia and anti-Sovietism; advocacy of "a new unity" instead of proletarian internationalism; and "various revisionist, nationalist, and clerical concepts." Many of the issues on this bill of particulars had been overworked already and awakened little new attention. ${ }^{29}$ However, some of the issues served as the focus for a lively new debate engaging both Soviet and East European authors. Would or

2a The June 21 article appeared to have lifted certain passages from an article in the April 1984 issue of Voprosy Istorii KPSS, by O. V. Borisov (the pseudonym for Oleg Rakhmanin, first deputy head of the Central Committee's Department for Liaison with Communist and Workers' Parties of Socialist Countries and a noted China specialist).

20 The June 22 editions of Rudé Právo and Rabotnichesko Delo (Sofia) reprinted the full text of the Vladimirov article. The Poles carried a bland summary, and the Romanians, Hungarians, and East Germans barely mentioned it. 
would not Moscow allow room for East European governments to undertake foreign political action that they deemed to be consonant with their own national economic and political interests? How much input would they be allowed to have into Soviet strategic interaction with the West? Would Soviet coordination be loose and cooperative or tight and disciplinarian?

Barely had the Vladimirov article seen the light of day, when the CPSU journal Kommunist published an article by Oleg Bogomolov, director of the Institute of Economics of the World Socialist System, arguing that national interests among socialist countries need not be identical, and that to ignore such interests would do more harm than good. The same issue also included a spirited defense of Hungary's reforms, written by Károly Németh, János Kádár's deputy. ${ }^{30}$ Romania's Nicolae Ceauşescu quickly sprang to the defense of national interests, as did the Romanian press. ${ }^{31}$ By contrast, Czechoslovakia's Ivan Hlivka staunchly opposed "any kind of relaxation" in efforts to increase bloc unity, and stressed the view that Soviet foreign policy was conducted "not from positions of toothless pacifism, barren objectivism, and unprincipled compromise with the class enemy, but from clear-cut class positions." ${ }^{32}$

In August, a well-known Soviet political commentator, Nikolay Shishlin, tried to square the circle, arguing that while each socialist country "has its own specific national interests [which] do not disappear overnight merely with the establishment of socialism ... it is equally obvious that the fundamental interests of the socialist states coincide; they are identical." ${ }^{33}$ In an interview with Radio Budapest that was broadcast on August 31, Izvestiya commentator Aleksandr Bovin praised small and medium-sized states for their ability to "find zones of agreement" and "play a balancing role" in international affairs. ${ }^{34}$ While Bovin's comments were ostensibly about small non-socialist countries, the Hungarian radio audience could hardly have missed the difference between his views and those of Vladimirov, who had stated:

What kind of mediation by this or that socialist country can help solve conflicts between the USSR and the USA, when the foreign policy of the USSR and the Marxist-Leninist core of world socialism [i.e., the bloc] is identical on all basic international issues?

\footnotetext{
30 Kommunist (Moscow), No. 10, signed to press on July 3, 1985. Nemeth had been designated Kádár's "deputy" at the March congress of the Hungarian party. See Népszabadság (Budapest), Mar. 29, 1985.

${ }^{31}$ For Ceauşescu's speeches, see Scînteia, July 12, 1985; and Agerpres, July 24, 1985; for articles, see Era Socialista (Bucharest), Nos. 13, 18, and 19, July 10, Sept. 25, and Oct. 10, 1985
}

The more relaxed Soviet posture was also evident at the October Pact summit in Sofia. The final communiqué appealed not to "socialist internationalism," but to "common fundamental interests and goals ... [and a] Marxist-Leninist world outlook." Cooperation and integration were to be pursued "on the basis of a harmonious combining of national and international interests." ${ }^{35}$ Although one would have to judge that Hungary, East Germany, and Romania had scored a point, Czechoslovakia's Hlivka still averred that the Sofia document "reaffirmed the loyalty of the fraternal parties and countries to revolutionary principles, to proletarian and socialist internationalism ....".36

The draft of the revised Soviet Communist Party Program, published on October 26 in Pravda and Izvestiya, ${ }^{37}$ came out strongly for economic integration - not only as a source of renewed growth, but also as a means of shielding the community against "hostile actions of imperialism" as well as the "economic crises and negative processes inherent in capitalism." On the role of small states in world politics, the document was less adamant:

All states, large and small, regardless of their capabilities, geographic situation, and social systems, can and must participate in the search for solutions to acute problems, the resolution of conflicts, the reduction of tensions, and the curbing of the arms race.

Despite such language, Michal Štefanák, head of the International Affairs Department of the Czechoslovak Communist Party's Central Committee, interpreted Soviet foreign policy, as shown in the Program, to be "profoundly internationalist and class-based." ${ }^{38}$

In Hungary, various officials weighed in with statements that collectively amounted to a comprehensive policy pronouncement defending their country's independent course, albeit within the parameters of continued membership in the Soviet bloc. Party secretary Matyas Szürös suggested that "there are no permanently valid solutions that yield successful results regardless of the specific conditions," and he entered a plea for "proper adaptation" of the basic principles of communism to specific national circumstances, an appeal that he related not only to Hungary's foreign

\footnotetext{
32 Rudé Právo, July 9, 1985.

${ }^{33}$ Novoye Vremya (Moscow), Aug. 23, 1985. The next day, the Hungarian party newspaper Népszabadsag excerpted the Shishlin article at length

${ }^{34}$ Radio Budapest, Aug. 31, 1985, 4 p.m., trans. by RFE monitoring service.

${ }^{35}$ Pravda, Oct. 24, 1985.

36 Pravda (Bratislava), Oct. 29, 1985.

${ }^{37}$ For a transiation, see CDSP, Nov. 27, 1985, Special Supplement.

3s Rudé Právo, Nov. 12, 1985
} 
policies, but to its domestic policies as well. ${ }^{39}$ First Secretary Kádár, writing on- the eve of the ReaganGorbachëv summit, saw the upcoming meeting of the superpowers as vindicating the comportment of Hungary and East Germany in $1984 .^{40}$ Ferenc Havasi, a member of Hungary's Politburo and the party secretary in charge of economic affairs, soon thereafter defended the "modernization" (i.e., the continuation and extension) of the country's economic reforms, ${ }^{41}$ and Németh opened a national conference on inner-party democracy with the argument that "history cannot serve as a collection of examples that appear to justify the circumstances of today, nor can one build the future from the past alone." 42

At the Kremlin's November 7 reception commem. orating the Bolshevik revolution, Gorbachëv noted the "exceptional importance" of the October meeting of Warsaw Pact leaders in Sofia and acknowledged that the Soviets have "immense respect" for the experience of their partners and "value the fraternal aid and friendly advice of comrades in the struggle [for socialist transformation]." He added that the USSR was "always ready to share [its] knowledge and experience with them."43 As if to highlight this cooperative spirit, Gorbachëv stopped off in Prague on November 21 on his way home from the Geneva summit meeting in order to brief Pact leaders (a move that may also have been designed to diminish the possibility of a backlash at home from some of his more diehard Kremlin colleagues). In the face of the "complicated" contemporary international situation, the allies pledged "unity and togetherness" and "class-based solidarity."44

Hungary and East Germany were swift to pick up the ball in the aftermath of Geneva. Gyula Horn, a secretary in the Hungarian Ministry of Foreign Affairs, observed that the two East European states had been correct in pressing for damage limitation and a resumption of détente..$^{45}$ In Germany, the Socialist Unity Party's Central Committee convened to hear

${ }^{30}$ Népszabadság, Nov., 2, 1985. A translation appears in FBIS-EEU, Nov. 27, 1985, pp. F/6-11. Neues Deutschland was quick to reprint salient passages of the Szüros article in its Nov. 6, 1985, issue. Steven Koppany analyzes the Szürös article in Radio Free Europe, Hungarian Situation Report (Munich), No. 13, Dec. 6, 1985.

${ }^{4}$ See New Hungarian Quarterly (Budapest), No. 45, Winter 1984; in Hungarian, Magyarország (Budapest), Nov. 3, 1985.

"Nepszabadság, Nov. 7, 1985, trans. in FBIS-EEU, Nov. 29, 1985, pp. F/3-9.

${ }^{42}$ Radio Budapest, Nov. 21 and 22, 1985, 12 noon and 10 p.m., respectively (trans. by RFE monitoring service). See also Népszabadság, Nov. 22, 1985

49 Pravda, Nov. 8, 1985.

4 Pravda, Nov. 22, 1985. The CPSU Politburo's statement on the Geneva summit alluded to the Prague pourparler's commitment to "joint peaceful positions" but also spoke of unity based on "class solidarity." Ibid., Nov. 26, 1985. The Prague stopover marked an unprecedented fourth Warsaw Pact summit for the year.

45 Budapest Television, Nov. 21, 1985, trans. by RFE monitoring service.
Politburo member Werner Jarowinsky defend the efforts of East Germany and West Germany to help consolidate the Geneva results by using their specific weight in the two alignments. The meeting also removed from the Politburo Konrad Naumann, a hardliner known for his reservations concerning innerGerman rapprochement. ${ }^{46}$ And even Czechoslovakia seemed to want to be part of the new trend: Gustav Husák hastened to East Germany to sign a communiqué with Erich Honecker that stated:

Both parties . . noted the willingness of their governments to keep identifying new forms of cooperation with the countries of Western Europe, based on equality and mutual advantage, as stipulated in the Helsinki Final Act. . . .47

Time will tell, of course, whether all these statements will actually afford the East Europeans much room for maneuver. In this context, it is useful to go over the salient events of the year in bilateral relations between Moscow and the East European states.

\section{Hungary: Circumscribed Acceptance}

Why Grigory Romanov, a reputed hard-liner and Gorbachëv's rival (already destined for ouster?), was chosen to deliver the CPSU's message at the 13th $\mathrm{Na}$ tional Congress of the Hungarian Socialist Workers' Party (HSWP) at the end of March, we do not know. It could have been an indirect warning to the Hungarians that they should not take Gorbachèv's approval for granted, or it may have been a ploy to humble Romanov by making him deliver a more moderate and balanced message than he might have been inclined to make. In any case, Romanov's speech clearly conveyed the wish of Gorbachëv and the CPSU not to commit Moscow either to full support or to straight rejection of Hungary's reformist course. Romanov said that "there is no way of reliably safeguarding the national interests of each socialist state except by strengthening our community as a whole and by augmenting our traditions of proletarian and socialist internationalism." On the other hand, he defined the bloc as a community in which "there is no place for relations of domination and subordination, the foisting of some people's will on others, or for mechanical

\footnotetext{
* Neues Deutschland, Nov. 23, 1985. For a translation of a broadcast of Jarowinsky's speech by ADN's International Service in German at 1626 GMT, Nov. 22 , 1985, see FBIS-EEU, Nov. 26, 1985, pp. E/1-7.

"Rưó Právo, Nov. 27, 1985.
} 
standardization." In other words, reformist particularism in Hungary could go on, provided due respect was paid to bloc-wide tenets as set by Moscow: Romanov noted "the high level of trust and mutual understanding" between the CPSU and the HSWP leaderships, and spoke approvingly of the exchange of experience in "improving the methods of management in the national economy and in developing democracy." 48

Romanov also highlighted the need to consolidate "our states' economic independence from the West":

Of course we are in favor of developing business relations with the capitalist countries alongside the consolidation of socialist economic integration. However, we build these relations in such a way as to prevent the imperialist forces from exploiting economic levers as a means of political pressure and interference in the affairs of the sovereign socialist states.

The CPSU Politburo report reviewing Romanov's visit said that the HSWP congress had demonstrated "a further consolidation of socialism's positions in Hungary" and had contributed to "enhanced cohesion of the countries of the socialist community." 49 It was not clear in Budapest how such a somber assessment gibed with the reaffirmation of reformist lines at the congress itself. ${ }^{50}$

Things looked up when Prime Minister György Lázár was dispatched to Moscow to open a Hungarian exhibition on April 1. Gorbachëv apparently avoided the usual internationalist and integrationist exhortations and wished the Hungarians success in fulfilling their congress decisions. ${ }^{51}$ He must have known that the main resolution of the congress postulated further reforms.

Moscow continued to signal positive attitudes, if not explicit approbation toward Hungarian reforms. At a Soviet-Hungarian symposium on reform concepts held in Moscow at the end of May and the beginning of June, István Huszár, Béla Csikós-Nagy, and other

\footnotetext{
40 The full text appeared in Pravda, Mar. 27, 1985

4 Ibid., Apr. 5, 1985.

${ }^{50}$ HSWP Central Committee member and Népszabadság commentator Péter Rényi,
} when asked by the Second German TV Channel whether the pace of reforms would be maintained, said, "I believe so. Insofar as one can measure reforms on a speedometer, I would even venture to say that they will now move faster." ZDF, 9:45 p.m., Mar. 29, 1985, trans. by RFE monitoring service.

${ }^{51}$ See the communiqué in Pravda, Apr. 2, 1985. Kádár doubtless would have liked to have gone himself, but did not - whether for health reasons (exhaustion after the HSWP congress) or because Gorbachëv did not yet consider it opportune. As it was, Lázár's reception by the Soviet General Secretary contrasted with the failure of Romanian and Bulgarian counterparts - also in Moscow at about the same time - to be granted audiences with the new CPSU chief.
Hungarian specialists met Pëtr Fedoseyev, Dzherman Gvishiani, Abel Aganbegyan, and Oleg Bogomolov. Upon their return to Hungary, Huszár acknowledged that some questions concerning "commodity and price relations" were not viewed "in quite the same way" by the two sides, but on balance he assessed the conference as a positive development "based on complete mutual confidence." 52

As noted above, in July the Soviet party journal Kommunist published an article by HSWP Politburo member Károly Németh that reiterated in unusually candid fashion the Hungarian leadership's intention to go ahead with innovation, including expansion of worker influence on management and "an increase in inner-party democracy." The HSWP's policy, he wrote, "is in need of constant renewal. ... The party is guided by principles, but not by dogma . . . , and the anwers that were being given decades ago, or even 10 or 20 years ago . . . no longer meet the needs of today. ${ }^{53}$ Bogomolov's article in the same issue of Kommunist implicity provided a theoretical justification for Németh's defense of his country's unorthodox approaches. ${ }^{54}$

In a September interview, CPSU Central Committee member and Director of Moscow's Institute for the Study of the USA and Canada Georgiy Arbatov described Moscow's view of the Hungarian experience with market forces:

It is accepted as being successful, although it has some complications, which the Hungarians speak about. At the same time, nobody can automatically take a model from another country and implement it. I think the Hungarian comrades - and I talk with them about it - would be the first to be appalled if we just took their model and implemented it in our country. ${ }^{55}$

Kádár went to Moscow in September for talks with Gorbachëv. The resulting communiqué emphasized "common experiences and the general laws of the building of socialism," but also acknowledged "national characteristics." It did not, however, mention Hungary's reforms or the Soviet attitude toward them. In an atmosphere of reported "complete unanimity of views," Gorbachëv accepted an invitation to visit Hungary. ${ }^{56}$

\footnotetext{
52 MTI, May 28, 1985; also Népszabadság, June 1, 1985.

${ }^{53}$ Loc. cit.

54 The HSWP held a national conference on "inner-party democracy" on November 21-23, 1985, at which both the themes discussed and the conclusions drawn were evocative of the Prague Spring of 1968. HSWP Deputy General Secretary Károly Németh delivered the main address. See Népszabadság, Nov. 22 and 23, 1985.

${ }^{35}$ The Los Angeles Times, Sept. 27, 1985.

so Népszabadság, Sept. 26, 1985.
} 
This limited evidence suggests that Gorbachëv's acceptance of Hungary's reformist course is qualified. First, although the reforms are being accepted, the Soviet leaders avoid giving them full and unequivocal public endorsement. Second, the Hungarians are being reminded that they must observe "the general laws of socialism," both by keeping domestic developments under party control and by exercising caution in their dealings with the West. Third, although a limited application of some Hungarian experiences has been hinted at, a replication of Hungarian reforms in the USSR is being ruled out, and the reformist course is not being prescribed for other East European allies individually or collectively. Fourth, the Hungarians are required to continue their participation in economic integration and to support the foreign policy initiatives of the bloc, particularly those affecting Soviet strategic interests. The limits have thus been established quite clearly. ${ }^{57}$

\section{Handling Honecker}

In 1984, Moscow and East Berlin fell out over the kind of East-West policy to be pursued by Moscow's allies in the wake of the deployment of intermediaterange nuclear forces (INF) in Western Europe and the USSR's confrontational posture in response. More particularly, how close inner-German relations should be within the global East-West climate became a bone of contention. Moscow eventually prevailed on Honecker to cancel an announced visit to West Germany. ${ }^{58}$ Would Gorbachëv now loosen the grip?

The East Germans were openly hopeful that Gorbachëv would "restore energetic leadership . . . and end the confusion that overshadowed relations between Moscow and its key ally [read East Berlin] last year." ${ }^{59}$ On the day of Chernenko's death, Honecker praised West German Chancellor Helmut Kohl's State of the Nation speech, an address that Moscow had criticized not long before. ${ }^{60}$ Shortly after arriving in

\footnotetext{
${ }^{57}$ The resuits of Kádar's talks with Gorbacherv were similar to those he had held with Andropov during his previous visit to Moscow in July 1983. Indeed, the

Gorbachëv-Kádár communiqué specifically referred to this earlier visit and to satisfactory implementation by both sides of agreements reached then. On the earlier meeting, see Alfred Reisch, "Kadar Policies Get Seal of Approval from the Soviet Leadership?" RFE, Background Report, No. 195, Aug. 11, 1983.

${ }^{58}$ For analysis of the 1984 tribulations, see Ronald D. Asmus, East Berlin and Moscow: the Documentation of a Dispute, Munich, Radio Free Europe, Occasional Paper Number One, 1985.

${ }^{58}$ From a Reuter despatch from East Berlin, Mar. 12, 1985, reporting comments of East German officials to Western diplomats. West German Economics Minister Martin Bangemann reportedly had a talk with Honecker in which the East German leader "seemed to be encouraged by Gorbachëv's appointment."
}

Moscow for the Chernenko funeral, Honecker met with Kohl for more than two hours in a guest house in Lenin Hills. In a joint statement, the two declared their hope for a new era in East-West relations and pledged to develop "normal and good relations" between their countries. ${ }^{61}$

Honecker's pace was too fast for Gorbachëv. Less than 10 days later, Andrey Gromyko summoned East German Foreign Minister Oskar Fischer to Moscow and enforced the adoption of a tough and unbending joint communiqué that indicated Moscow would determine the rules of the game. ${ }^{62}$ The Soviets clearly wanted to be seen as determining when and how confrontation was to be shifted to accommodation and not as being compelled to act under pressure from an eager client.

The Bonn government was perceived in Moscow as the most likely supporter (next to Britain) of US President Ronald Reagan's Strategic Defense Initiative (SDI), the prime target of the latest Soviet peace offensive. Driving a wedge between SDI supporters and the opponents would be more valuable than continued efforts at decoupling Bonn from Washington, at least in the short run. Honecker's "commonality of interests" with West Germany would stand in the way. It would be inappropriate for East Berlin to behave as if SDI were not an issue, or as if it concerned only the US-Soviet "grand" relationship and not ties between the lesser powers.

Finally, Moscow had decided that the "correct" ideological way of celebrating the forthcoming anniversary of the end of World War II was to keep West Germany dangling on the "revanchist" hook. Unseemly haste. in restoring friendliness between Kohl and Honecker would run counter to this carefully orchestrated anniversary program. It is possible, too, that the Soviets had already anticipated an upsurge in the political fortunes of West Germany's Social Democrats (the SPD) and wanted to steer Honecker clear of excessively close relations with the governing coalition of Christian Democrats, Christian Socialists, and Free Democrats.

Whatever the reasons, the Soviets offered the East German leader an alternative strategy (or so it seems in hindsight). He was apparently asked to redirect his Westpolitik toward countries other than West Germany and to downplay relations with Bonn to sub-

${ }^{*}$ Neues Deutschland and Frankfurter Allgemeine Zeitung of Mar. 11, 1985; cf. TASS of Feb. 28, 1985.

" ADN International Service in German, 2058 GMT, Mar. 12, 1985, trans. in FBIS-EEU, Mar. 13, 1985, p. E/1

2. For the text of the communique, see Izvestiya (Moscow), Mar. 21, 1985. 
governmental and trade levels while in the meantime cultivating the SPD. Only after the Soviets decided to change their own stand vis-à-vis the West in general and, perhaps, Bonn in particular, would Honecker be allowed to deal with Kohl again. He would then, in fact, be able to do so from a position of strength, having in the interim proven himself to be an important European statesman. ${ }^{63}$

Honecker appears to have accepted this scenario without demur. Yet the communique signed after a May meeting with Gorbachëv in Moscow showed some signs of unresolved issues. Despite a stated mood of "cordiality and complete unanimity," there was no declaration that relations between the two countries were satisfactory, and "mutual resolve was expressed to further perfect relations along party, state, and public lines." 64 Viktor Grishin's subsequent mid-May visit to East Berlin yielded yet additional evidence that Honecker was being reminded to behave as told. In the words of the communiqué,

Erich Honecker pointed to the complete agreement in views about current issues of world politics, the strug gle for the preservation of peace, and further strengthening of the unity and united nature of the socialist community, which had been emphasized so strongly during his meeting with Mikhail Gorbachëv. ${ }^{65}$

The document also included the already-cited GDR pledge to honor Warsaw Pact obligations "in the future, too."

A curious incident in mid-April may explain this last development. In two consecutive issues-April 15 and 16-the otherwise protocol-conscious East German party newspaper Neues Deutschland referred to the Soviet troops stationed in East Germany as "Group of Soviet Forces in the German Democratic Republic," and not (as was official and customary) as "Group of Soviet Forces in Germany," a formula designating Soviet rights in all Germany, East and West. The then commander of these troops, Soviet Army General Mikhail Zaytsev, went out of his way to correct the mistake, using the old designation no fewer than four times in a speech delivered on April 16; Neues Deutschland dutifully reprinted the general's speech the next day with the correct formula, and has not erred since. ${ }^{66} \mathrm{~A}$ West German journalist noted in this context:

a9 This interpretation is offered in Barbara V. Flow, "Honecker Woos NATO Countries" and "Mixed Signals in Inter-German Relations," RFE, Background Report, Nos, 42 and 76, May 9, and Aug. 8, 1985.

${ }^{4}$ Pravda, May 6, 1985
As regards the rights and responsibilities of the Soviet Union within the Four-Power agreements on Germany and Berlin, West German and West Berlin negotiators have precisely in recent months frequently learned from their GDR interlocutors that this or that is at the moment "impracticable" because "our friends" - that is, the Soviets - have said so. ${ }^{67}$

Nonetheless, East Germany was champing at the bit. Beginning late in the summer of 1985, East Berlin started a series of leaks that when combined con. veyed a common theme. Honecker, it was implied, wanted to go to Bonn at long last, but had to wait for Soviet approval, which Gorbachëv had promised to give only after the summit meeting with Reagan in Geneva. ${ }^{68}$ More important still, the East Germans once again joined forces with the Hungarians, this time to postulate three tenets that they believed to be instrumental for their own conduct of policy toward the West, as well as their demeanor inside the bloc. First, both apparently asked Gorbachëv to show flexibility and readiness to compromise when dealing with the United States. ${ }^{69}$ Second, they successfully induced Moscow to accept the notion that small and medium-sized states on both sides of the ideological divide have a role of their own to play in influencing the behavior of the superpowers. And third, they argued in favor of an undogmatic interpretation of internationalism that would allow for the acceptance of national peculiarities and interests.

Yet, one must be careful in assessing prospects for East German freedom of action. On the one hand, the Honecker regime has undoubtedly come of age and, as an economically important partner of the USSR, the GDR rightly claims more room for itself than its role as a mere Soviet military instrument allowed it to have in the past. On the other hand, however innovative and versatile Gorbachëv may turn out to be, he is not likely to surrender suzerainty where it matters most. Dovetailing of interests rather than accenting of differences will constitute the center of gravity of future Soviet-East German relations. Moreover, Honecker has not been a reformer at home. East German policies of economic intensification have already met with Soviet approbation and possibly even emula-

\footnotetext{
es See fn. 15.

see Tagesspiegel (West Berlin), Apr. 17, 1985, for a more detailed account.

a7 Frankfurter Allgemeine Zeitung, Apr. 18, 1985.

${ }^{88}$ Honecker conveyed this message himself in an interview in Saarbrücker Zeitung, Nov. 13,1985 . For a good summary of East German positions at that pre-summit juncture, see "Honecker's Pollcy of Wait and See," Neve Zürcher Zeitung, Nov. 13, 1985.

"9ee Louis Wiznitzer's article filed from Paris to The Christian Science Monitor (Boston), Nov. 6, 1985, which references unnamed East European sources.
} 
tion. Hence, Soviet chastisement for GDR foreign policy transgressions is likely to be carefully balanced with good marks for East Berlin's useful domestic economic policies.

\section{Poland the Insoluble}

The plan for Poland which has been crystallizing over the past year appears essentially identical to the concept of "normalization" formulated in basic contours four years ago, under Brezhnev. It seems to have the following features:

- General Wojciech Jaruzelski will stay at the helm as the best strong man available.

- His priority task will now be to revivify the Polish United Workers' Party so that it, rather than the army and the government, once again becomes the undisputed ruler of the country. ${ }^{70}$

- The Polish government will concentrate on straightening out the economy, at first not along the lines of the reformist concept of 1981 (which contained a number of "Hungarian" features) but rather in the Gorbachëv manner." 1

- Soviet-Polish relations will form the core of Poland's economic recovery program. ${ }^{72} \mathrm{~A}$ renewed attempt to spur modernization through capitalist assistance, such as the one undertaken by Gierek with Brezhnev's blessing in the early 1970's, will not be tolerated. Neither will Poland become too friendly with the West in the political and cultural fields, lest this afford the West an opportunity to link up with the opposition inside the country.

- The state will maintain a non-confrontational but distant relationship with the Church; the two are not to be seen as acting in unison on any of the essential problems facing Poland.

- The state will alternate between toughness toward dissenters and apparent accommodation designed to condition the public to accept the regime's monopoly in domestic politics as irreversible.

- The regime will not enter into dialogue with underground Solidarity, but will not be averse to simulated consultations with the new official trade unions and possibly even the self-management organs in factories. The objective will be to weaken residual sympathy among industrial workers for the defeated union and to persuade the public of the futility of reliance on clandestine organizations for matters affecting everyday life.

In April, Gorbachëv remained for a day in Poland for bilateral talks after the Warsaw Pact renewal cere-

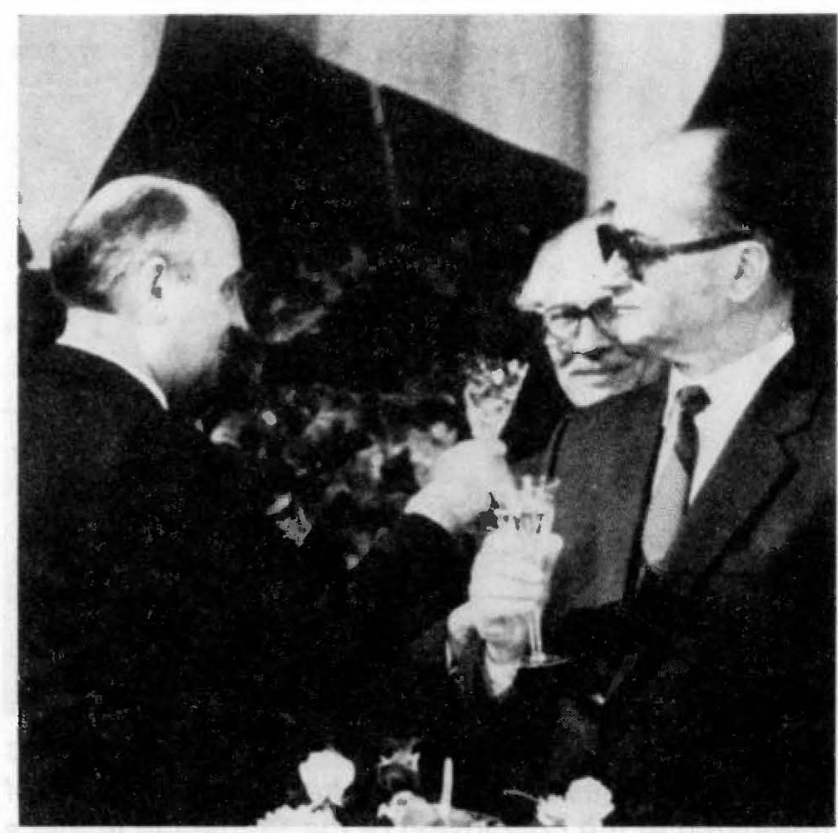

Toasts are exchanged at the April 26, 1985, banquet in Warsaw marking renewal of the Warsaw Pact: at left, Soviet leader Mikhail Gorbachëv; at center, East Germany's Erich Honecker; at right, Poland's Wojciech Jaruze/ski.

-REUTERSIBETTMANN.

monies. The talks produced a communiqué that spoke of "a spirit of unity and cordial friendship," but it lacked the usual references to confidence, mutual understanding, and identity of views. Gorbachëv was said to have confirmed the Soviet Union's constant,

\footnotetext{
10 The Central Committee of the PUWP met on May 12-13 to discuss "the
} effectiveness of party work and ways of improving its quality." The leadership said it was "increasing the scope of participation of party bodies and party members in the process of policy. and decision-making." Trybuna Ludu (Warsaw), May 12-15, 1985, carried reports on the session. When personnel changes were made in the wake of the Sejm elections of October 13, Jaruzelski gave up the premiership for the more ceremonial chairmanship of the Council of State, while retaining his position as party leader. Polish official sources and Western observers alike interpreted this as an indication of a decision to focus on party matters. See Polish government spokesman Jerzy Urban's remarks to foreign press correspondents as reported by the Associated Press and Deutsche Press Agentur on Nov. 12, 1985, as well as Jaruzelski's speech at a PUWP ideological conference on Nov. 27, 1985 (Trybuna Ludu, Nov. 29, 1985), also The Washington Times, Nov. 12, 1985; and Der Spiegel (Hamburg), Nov. 13, 1985

"This emphasis is clear from the proceedings of the PUWP's economic conference in Poznan on May 31-June 1, and from the speech of the new Prime Minister Zbigniew Messner to the Sejm on November 12. On the Poznan meeting, see FBIS-EEU, June 3 1985, pp. G/1-17; on Messner's speech, see Warsaw Domestic Service in Polish, 1445 GMT, Nov. 12, 1985, trans. in FBIS-EEU, Nov. 18, 1985, pp. G/3-28.

${ }^{72}$ The states signed two economic agreements on October $7:$ one on cooperation in the period 1986-90, including provisions for Soviet use of Polish industrial capacity; the other on the rescheduling until after 1990 of Poland's debt to the USSR-amounting to more than 5 billion rubles - and toleration of Poland's negative balance of payments with the Soviet Union until the end of 1987. See Trybuna Ludu, Oct. 8, 1985; and Roman Stefanowski's article in RFE, Polish Situation Repoct (Munich), No. 17, Oct. 26, 1985 


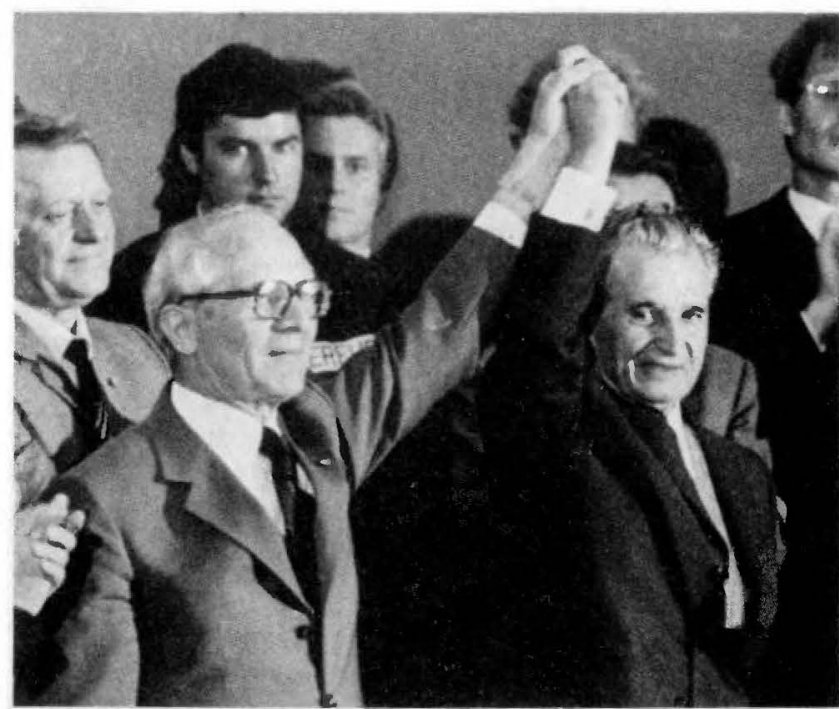

East Germany's Erich Honecker, left, and Romania's Nicolae Ceauşescu raise their hands in a gesture of friendship at the conclusion of the Romanian leader's May 29, 1985, visit to the German Democratic Republic.

-ADN Zentralbild from EASTFOTO

unwavering solidarity with the Polish party and the Polish people and to have expressed Moscow's interest in fully overcoming the crisis, achieving stabilization, and strengthening the positions of socialism. Jaruzelski was not mentioned by name, an unmistakable sign that Moscow was not putting all its eggs into his basket. ${ }^{73}$

\section{Waiting Out Ceauşescu}

Gorbachëv has not acted overtly with respect to Romania; he has not even met individually with the ailing Ceauşescu. ${ }^{74}$ In the meantime, economic necessity and Soviet pressures have forced Romania to increase its trade and other cooperative undertakings with CEMA countries, and even agree to participate in

\footnotetext{
${ }^{73}$ Trybuna Ludu, Apr. 28, 1985

${ }^{74}$ Most recently, Ceauşescu's appearance during his mid-December visit to Yugoslavia was said to be worn and haggard. See Die Presse (Vienna). Dec. 19, 1985; and Chicago Tribune, Dec. 24, 1985

${ }^{75}$ Radio Moscow broadcasts in Romanian assert that the USSR is stepping up oil deliveries to Romania to keep her refining capacities functioning. Statistical services in both countries show an increase in deliveries in 1984 and the first half of 1985 , but these unreliable sources do not make it clear how much of the increased Romanian oil bill reflects expanded physical deliveries and how much it reflects rising prices, or how much is paid for in hard currency or "hard-currency goods." Programs planned for the 1986-90 period apparently entail fairly substantial Romanian participation in gas extraction on Soviet teritory and in the builidng of pipelines, alongside other CEMA states. See Paul Gafton's articles in RFE, Romanian Situation Report (Munich). Nos.7 and 8, Apr. 9 and May 14, 1985
}

projects on Soviet territory. ${ }^{75}$ Simultaneously, the importance of Romanian economic connections with the West has diminished perceptibly. The bulk of export earnings has been earmarked for rapid payoff of earlier loans and related interest expenses, thereby further reducing the room for purchases of modern equipment, spare parts, and raw materials on Western markets. Bucharest's economic crisis and the resulting accommodation with the USSR has tended to devalue Ceauşescu's international standing.

At the same time, Romania continues to be a nuisance within the bloc. Gorbachëv could not possibly have welcomed Ceauşescu's May call for reductions in WTO defense outlays. ${ }^{76}$ Moreover, in a reprise of the political alignments of 1984 (which had seen Honecker, Kádár, and Ceauşescu striking a somewhat independent posture vis-à-vis the Soviet Union), Honecker received Ceauşescu in East Berlin in late May. Although the resulting communiqué adhered more closely to the measured position of the GDR than to the tenets usually verbalized by the Romanians, it made no mention of "socialist internationalism." 77 On the day of Ceauşescu's arrival, the East Germans praised him for relying on "principles of independence and national sovereignty," and Romania was said to "occupy a respected place in the family of the fraternal socialist countries." 78

Nicolae Ceauşescu's persistent pursuit of the theme of independence, however futile the end result may turn out to be in Romania's own case, cannot be totally written off. Twenty years of rhetoric and shadow-boxing with the Soviets over this issue have given it a life of its own. Not even Gorbachëv can ignore the impact it has had on attitudes in the empire over which he now presides. Moreover, all was not empty talk and sham argumentation. Romania engineered the departure of Soviet troops from its land and refused to allow their return. It rejected Khrushchev's concept of hierarchic economic integration in the bloc at a time when all the others were willing to accept it. Without Romania, the economic landscape of the empire could have changed then, making subsequent economic reforms more difficult. Ceauşescu repudiated the invasion of reformist Czechoslovakia and the ensuing Brezhnev Doctrine of limited sover-

${ }^{36} \mathrm{See} \mathrm{fn} .14$. For a round-up of recent developments in the Romanian-Soviet dispute, see Anneli Maier's article in RFE, Romanian Situation Report, No. 12, Aug. 13, 1985.

"See Scînteia, May 31, 1985; a translation of the communiqué as released by ADN international Service in German, 1701 GMT, May 30, 1985, can be found in FBIS.EEU. May 31, 1985, pp. E/6-11

${ }^{78}$ Neues Deutschland, May 28, 1985; and ADN International Service in German, May 28, 1985, trans, in FBIS-EEU, May 29, 1985, p. E/1. 
eignty, giving heart to others. He denied full cooperation to Warsaw Pact military programs, including maneuvers on his territory and-possibly, although we do not know it for certain - training exercises outside the European theater. ${ }^{79}$ Romania opposed the Soviet policies that culminated in the rifts with China, the Eurocommunists, and Israel. It created, albeit clumsily, a body politic and body theoretic that continue to balk Soviet desires for the homogeneity of the bloc and unbridled Muscovite hegemony over it.

\section{The Bulgarian Connection}

Bulgaria's Todor Zhivkov, like Czechoslovakia's Gustav Husák, had the distinction of having two individual meetings with Gorbachëv in 1985: one during a visit to Moscow on June 5-7, the other when the Soviet leader stayed behind in Sofia on October 2425 , after the Warsaw Pact summit. The first visit produced the usual citations of brotherly cohesion and consensual opinion, as well as a fourth Order of Lenin for Zhivkov. ${ }^{80}$ After the second meeting, however, Gorbachëv told workers in a Sofia factory (which exports most of its machine tools output to the USSR): "We briefed each other ... in a comradely fashion, not evading a few prickly issues." ${ }^{11}$

Observers had noted a few "prickly issues" even in pre-Gorbachëv times, relating in particular to the Bulgarian nationalism of Zhivkov's late daughter, Lyudmila. ${ }^{82}$ But other matters were probably on Gorbachëv's mind when he took Zhivkov to task: the botching of Bulgaria's terrorist and underworld connections, with special reference to the papal assassination plot; the unnecessary haste and brutality of the campaign to Bulgarize ethnic Turks; and Bulgaria's lackadaisical economic behavior. All three issues antedate Gorbachëv's accession, but he chose to administer the censure.

The extent of Bulgarian involvement in the attempted murder of the Pope and the connection of the then KGB chairman and Gorbachëv's mentor Yuriy Andropov with the event is not yet clear. What is certain is a rather intimate and unsavory association of the Bulgarian secret services with syndicated crime in the European underworld, especially its drug and arms smuggling branch, in which Turkish nationals play a significant role..$^{3}$ Even if the hand that guided Mehmet Ali Ağca in St. Peter's Square was not Bulgarian, the drawn-out tumult and revelations to which the act led, would justify displeasure.

Sofia's campaign to coerce ethnic Turks into adopting Bulgarian names, which began in the autumn of
1984, had essentialy been completed by February 1985, just before Gorbachëv's succession. There is no evidence of any Soviet opposition to this campaign, or to Bulgaria's long-term goal of "one Slavic nation." A Turkish reporter accompanying the speaker of the Ankara parliament, Necmettin Karaduman, on a six-day visit to Moscow in late May 1985 said that Karaduman asked Vasiliy Kuznetsov, first deputy chairman of the USSR Supreme Soviet, to intercede with Sofia. Kuznetsov purportedly refused "to intervene in another country's internal affairs." 84 if Gorbachëv criticized Zhivkov regarding the actions vis-àvis Bulgaria's Turks, one can only surmise that it was not the act itself but rather the handling of the campaign that provoked Soviet dissatisfaction.

Bulgaria's economic performance is probably the most important issue in what observers see as Gorbachëv's stern behavior toward this Balkan ally. Four factors seem salient. The first is Bulgaria's wasteful domestic energy sector and dependence on Soviet coal and oil deliveries. (An acute shortage of power made the winters of 1984 and 1985 critical periods, with extensive power cuts and equipment breakdowns that rivaled those of neighboring Romania.) More broadly, Moscow apparently did not like the way Bulgaria approached coordination of the two countries' five-year plans, for $1986-90 . .^{85}$

Second, the USSR has long criticized the poor quality of deliveries from Bulgaria, especially of engineering goods. ${ }^{86}$ When visiting the USSR in August

7 For a history of Romania's comportment in the Warsaw Pact, see Robert $L$. Hutchings, Soviet-East European Relations: Consolidation and Conflict, 1968-1980, Madison, University of Wisconsin Press, 1983; and David Holloway and Jane Sharp, Eds., The Warsaw Pact: Alliance in Transition, London, Macmillan, 1984. A recent journalistic summary appeared in Der Tagesspiege/ (West Berlin), Dec. 21, 1985.

" The occasion for the award remains a mystery. The citation refers to a "jubilee," but there was no obvious birthday or other anniversary being celebrated. See TASS in English, 1033 GMT, June 7, 1985, trans. in FBIS-EEU, June 7, 1985, pp. F/3-4.

"Pravda, Oct. 25, 1985. The Russian words for "prickly issues" were "ostryye ugly."

* On Lyudmila Zhivkova's "mystical reworking of Marxism-Leninism, her endorsement of traditional nationalism, her vigorous assertion of claims on Macedonia, her lavish celebration of Bulgaria's non-Slavic Thracian past, and her sponsorship of independent cultural and peace initiatives," see Stephen Ashley in RFE, Bulgarian Situation Report (Munich), No. 12, Nov. 7, 1985.

${ }^{8}$ Reports on Bulgarian involvements in the "sensitive issues" relating to drugs, arms, and other murky affairs have been plentiful. See, e.g., a report by the US Drug Enforcement Agency as released by USIA, July 26, 1984; The New York Times, Feb. 6, 1985; and Libération (Paris), Oct. 16, 1985.

*4 Hurriyet (Ankara), May 31, 1985, trans. in Foreign Broadcast Information Service, Daily Report: Western Europe (Washington, DC), June 4, 1985, p. T/1

ss See Rada Nikolaev' articles in RFE, Bulgarian Situation Report, Nos. 10 and 12 , Sept. 2 and Nov. 7, 1985. The first of these discusses Bulgaria's energy crisis; the second, a number of personnel changes, which included the dismissal of Stanish Bonev, chairman of Bulgaria's State Planning Commission, on October 18-an event that occurred one week before, and appeared connected with, Gorbachev's visit.

See, e.g., an interview with the Soviet Ambassador to Sofia, Leonid Grekov, in Pogled (Sofia), No. 26, July, 1985. 
1985, Bulgarian Communist Party Politburo member Stanko Todorov said:

We assured our Soviet comrades that Bulgarian workers were making great efforts to improve the quality and reliability of the products we export to the USSR. ${ }^{87}$

Third, the Soviets appeared displeased over lagging productivity levels, lax discipline, and excessive worker preoccupation with private pastimes and private enterprise. Soviet Ambassador Leonid Grekov said:

The attachment of (Bulgarian) workers to the land is not a simple problem. Many of your workers have houses in the countryside, gardens, vineyards, or they breed livestock. When they return to their jobs, it is only natural that they rest after having attended to these activities. ${ }^{\text {s8 }}$

The Bulgarians responded by tightening control over cadre work and by launching a campaign against corruption, incompetence, and indiscipline..$^{89}$

Fourth, there must have been some displeasure over the "embourgeoisement" and generally lax ideological manners of Bulgarian youth. A rather harsh decree was issued in October 1985 to tighten supervision and indoctrination of the 16-to-19 age group. ${ }^{90}$

Economic decline would have become the concern of Bulgarians even without Soviet criticism. It appears that neither the "new economic approach," first formulated in 1977, nor the "new economic mechanism," first introduced in 1982 and then amended in 1984, has brought the expected results. Reform Bulgarian style, hailed (together with the East German experience) as potentially capable of steering a communist economy between the Scylla of the command system and the Charybdis of marketization, seems to be foundering. Bulgarian economists have already begun to argue the case for a reform that would rest on market principles, as practiced in Hungary. ${ }^{91}$

It is difficult to link Gorbachëv's ascent to power with a wave of terrorist acts that has plagued Bulgaria

${ }^{87}$ Rabotnichesko Delo, Aug. 20, 1985

* Interview in Pogled, loc. cit.

* See two lengthy lead articles in Rabotnichesko Delo, Sept 9 and 15, 1985, and a series of critical articles in Trud (Sofia) running from August through November 1985

* On the decree and reasons for it, see interviews with the chief secretary in the Ministry of Education, in Vechernji Noviny (Sofia), Oct. 30, 1985, and with Minister of Education Aleksandar Fol, in Rabotnichesko Delo, Nov. 1, 1985.

" For example, economist Ivan Angelov argued in Trud of Sept. 20, 1985, that Bulgaria's New Economic Mechanism had failed and that full reliance on the market was preferable. of late - an explosion on a train, a parcel bomb, destruction of ski lifts, and fires on Sofia streetcars. But one thing is certain, the oft-ignored Balkan state has emerged from the doldrums with a bang, and will doubtless engage a goodly measure of the new Soviet leader's attention.

\section{Czechoslovakia's Non-Reform}

A Czechoslovak newspaper greeted Gorbachëv's ascent with the headline "Continuation of the Great Work" and pointedly emphasized the legacy of the hapless Konstantin Chernenko, ${ }^{92}$ an indication of Prague's unfailing loyalty to hard-line orthodoxy. Presumably, Czechoslovakia will continue-as it did during the Andropov period - to emulate Soviet campaigns to intensify and modernize production, uproot corruption, and tighten work discipline. At the same time, it will also likely pursue an "active foreign policy" of endless exchanges of official and semi-official visits with other nations as a means of softening its image as an oppressive regime; and to the same end, it may continue to treat dissidents with some moderation and afford some leeway to religious believers (even while blocking vitally required agreements with the Vatican).

But the current Czechoslovak leadership has no stomach for reforms, even economic ones, at this time. Party leader Gustav Husák told a June session of the Czechoslovak party Central Committee:

We will not take the road of any of the market-oriented concepts that would weaken the system of socialist collective property and the party's leading role in the economy. We have had bad experience with that kind of thing. ${ }^{.3}$

Resources for the next five-year plan are being allocated on the assumption that the command system remains essentially unchanged. The country's proportion of trade with the USSR is nearing 50 percent, and more than 80 per cent of overall trade turnover is with the socialist world. ${ }^{94}$

In its orthodoxy, Czechoslovakia sometimes even outdoes Big Brother. Barely a week before the May

\footnotetext{
22 Pravoda (Bratislava), Mar. 13, 1985

-3 Rudé Právo, June 19, 1985.

${ }^{94}$ According to the semi-annual (1985) plan fulfillment report, $46.2 \%$ of all Czechoslovak foreign trade was with the USSR and $80.3 \%$ with "socialist countries." Rudé Právo, July 26, 1985. For the increasingly awesome Czechoslovak economic entanglement with the Soviet Union, see also Hospodárské Noviny (Prague), May 31, 1985 .
} 
meeting of Gorbachëv and Husák in Moscow, the Soviet leader had told visiting Italian Communist official Gianni Cervetti that the idea of holding a world communist conference was simply not topical..$^{95}$ Yet in mid-June, Husák said he was convinced that "the unity and togetherness of the movement would be enhanced" if such a meeting took place..$^{96}$

Writing in Rudé Právo of July 9, 1985, Ivan Hlivka called for full recognition of the primacy of Soviet experience for bloc members, for total coordination of economic and political measures, for intensification of the influence of communist party organizations on intrabloc processes, and for rejection of those hoping to rely on the West in their modernization drives. Another Czechoslovak official interpreted the new version of the Soviet party program as demanding "improvement of political coordination in the Warsaw Pact" and as postulating faithfulness to MarxismLeninism by the ruling parties as the most important factor in a successful march forward. ${ }^{97}$

Husák presents Gorbachëv with a choice between what the former likes to call a politically stable and loyal Czechoslovakia under the present leadership and the dark threatening future that reformism would bring if it were allowed once again to raise its ugly head. Even if Gorbachëv were aware that Husák is exaggerating both the virtues of his own government and the perils inherent in reform, he could not remain indifferent to the argument. Gorbachëv has no shortage of problems and potential crises around him, and a placid, if inefficient, Czechoslovakia is better than another Prague Spring. Things may start happening when Czechoslovak economic inadequacy becomes more pronounced, but not a shadow of disagreement was allowed to seep into the communiqué issued after Gorbachëv stopped over in Prague on his way from the summit in Geneva in November and held bilateral talks with Husák before briefing the Warsaw Pact leaders collectively. ${ }^{98}$

\section{Conclusion}

In all, Mikhail Gorbachëv has set the signposts for Eastern Europe in a way that combines firmness with a good amount of understanding. He seems to have recognized that there are limits that he himself cannot overstep, as well as problems that his lesser allies have to cope with in their own way. He did not relax the Soviet grip on the area to the point where disintegration might, or almost certainly would, ensue. He has eschewed endorsing market-based reform for individual countries or as an underpinning of CEMA. He prodded all of the client states into domestic action designed to increase efficiency, discipline, and thrift, and he asked them to cut corruption and abuse of power. He affirmed Soviet primacy in coordinating the way the East-West relationship was to be shaped and conducted.

Nevertheless, Gorbachëv has fine-tuned rather than bulldozed. No East European leader has been toppled, and no established governmental mode has been changed. The Hungarians continue their reforms, and so far the Czechoslovaks go ahead with their non-reforms. He has conceded that national peculiarities and interests do not have to be trampled underfoot but could be amicably dovetailed in order to produce internationalist ideological satisfaction. He has given his client states the right to deal with the West as long as they eschew countering Soviet strategic objectives, comply with CEMA's integration plans, and avoid becoming dependent on Western economic mercies.

In other words, in not acting rashly either in tightening or in relaxing Soviet control over the area, Gorbachëv has acted optimally. By the same token, neither the centrifugalists nor the centripetalists can be fully content with what has come to pass.

In at least one respect Gorbachëv has so far failed to provide an adequate answer to the East European challenge. He has not charted a credible path toward making the region economically healthy. The East Germans and the Hungarians may yet achieve their own economic revitalization, but for the other countries, the post-industrial era of hi-tech modernization keeps receding into the more distant future. From any perspective, Marxist or not, this shakiness of the economic base should be cause for considerable concern.

\footnotetext{
\% L'Unità (Rome), May 22, 1985.

* Rudé Právo, June 19, 1985. On the world communist conference the Czechoslovaks had to backpedal. Vasil Bilak told the CC meeting on Nov 28, 1985 in one terse sentence: "Today we see that conditions for it are not yet ripe." Rudé Právo, Nov. 30, 1985.

"See Michal Ṡtefańák in ibid., Nov. 12, 1985

* Ibid., Nov. 22, 1985
} 


\section{Politics of Soviet Law}

\section{Robert Sharlet}

OLIMPIAD S. IOFFE. Soviet Law and Soviet Reality. Dordrecht, Martinus Nijhoff, 1985.

FRIDRIKH NEZNANSKY. The Prosecution of Economic Crimes in the USSR, 1954-1984. Falls Church, VA, Delphic Associates, 1985.

LOUISE I. SHELLEY. Lawyers in Soviet Work Life. New Brunswick, NJ, Rutgers University Press, 1984.

JOHN N. HAZARD. Managing Change in the USSR: The Politico-Legal Role of the Soviet Jurist. Cambridge, UK, Cambridge University Press, 1983.

JOHN N. HAZARD, WILLIAM E. BUTLER and PETER B. MAGGS. The Soviet Legal System: The Law in the 1980's. New York, Oceana, 1984.

Robert Sharlet is Professor of Political Science, Union College (Schenectady, NY). His books on Soviet law and politics include The New Soviet Constitution of 1977 (1980) and Pashukanis: Selected Writings on Marxism and Law (1980)-co-edited with Piers Beirne \& trans. by Peter B. Maggs.
OVER HALF A CENTURY ago, Yevgeniy Pashukanis, the preeminent Soviet legal philosopher of his day, declared that "for us revolutionary legality is a problem that is 99 percent political." Since that time, and especially since Stalin's death in 1953, substantial changes have occurred in the way the Soviet leadership governs Soviet society. Overt and systematic terror as a principal means of control passed from the scene some decades ago as the party-state shifted its emphasis from prerogative or administrative methods of governance to normative or legal ones. After Stalin, reliance on legal processes has been the general ruleexcept for "political cases" which continue to be dealt with administratively, albeit under a cloak of legality. The treatment of "political cases," relatively small in number but significant for their calculated violation of Soviet-style due process, is by now well-documented in Western literature. ${ }^{2}$

Less well known, however, is the day-to-day admixture of politics and law in the legislative and policy implementation process and in the more mundane spheres of civil law and criminal procedure. Although "socialist legality" is no longer 99 percent political, the Communist
Party of the Soviet Union, as the political sovereign, continues to interfere in the ordinary administration of justice in myriad subtle ways. However, the increasing availability in the West of authoritative accounts by émigré Soviet jurists is now beginning to shed some light on these heretofore hidden aspects of the Soviet legal system. The most recently published accounts, among them Olimpiad loffe's ${ }^{3}$ Soviet Law and Soviet Reality, Fridrikh Neznansky's ${ }^{4}$ The Prosecution of Economic Crimes in the USSR, 1954-1984, and those included in Louise Shelley's ${ }^{5}$ study

1 Yevgeniy B. Pashukanis, "The Soviet State and the Revolution in Law," trans. by Hugh W. Babb, in John N. Hazard, Ed., Soviet Legal Philosophy, Cambridge, MA, Harvard University Press, 1951, p. 280

2 See Peter Reddaway, Ed ، Uncensored Russia: Protest and Dissent in the Soviet Union, New York, American Heritage Press, 1972; and Ludmilla Alexeyeva Soviet Dissent: Contemporary Movements for National, Reiiglous, and Human Rights, Middletown, CT, Wesleyan University Press, 1985.

${ }^{3}$ Before emigrating from the USSR, Olimpiad loffe was chairman of the Department of Civil Law of Leningrad University Law School. He also played a major role in the post-Stalin drafting and recodification of Soviet civil law.

4 During his long career in the USSR Procuracy, Fridrikh Neznansky worked as a senior criminal investigator and served as a prosecutor in hundreds of cases handled by the Moscow City Procuracy. After leaving the Procuracy, he worked for several years as a defense attorney until his emigration in the late 1970's.

${ }^{5}$ Louise Shelley is an American criminologist (continued on p. 55) 
Lawyers in Soviet Work Life, reveal much about the preemptive role of politics in the ordinary legal process in the USSR. These insider accounts are beginning to enrich the analyses of Western scholars.

FEW WESTERN SPECIALISTS on Soviet law and politics have doubted that the party controls the formal legislative process, but they were not familiar with the exact modus operandi of this control. Émigré scholarship is now helping to fill this gap. It reveals that the Politburo, acting on the advice of the Central Committee Secretariat, determines the long-term lawmaking agenda and assigns the various legislative drafting tasks to appropriate state institutions and organizations. The substance of every new law is predetermined in advance by the party leadership by means of "political directives" that are binding on the drafting and enactment agencies. ${ }^{6}$ Of course, for a legal act as complex as the new USSR Constitution of 1977, a mere political directive was not sufficient; the Administrative Organs Department of the party Secretariat closely supervised the Constitutional Commission and its drafting committees in order to ensure an outcome consistent with the will of the party as ultimate legislator. This department of the Secretariat paid special attention to novel or unusual proposals that arose in response to the leadership's political directives on the Constitution. Thus, for example, the head of the Administrative Organs Department

specializing in Soviet law. Her study is based on in-depth interviews with 25 former Soviet jurists now living in the West, the majority of whom had served as legal advisors to economic enterprises, local governments, and social organizations, or worked as state arbitrators. Some of her respondents were also defense attorneys.

- See Olimpiad S. loffe and Peter B. Maggs, Soviet Law in Theory and Practice, New York, Oceana, 1983, pp. 99-101. vetoed a constitutional clause that would have created a tier of tribunals to exercise judicial review over administrative decisions. ${ }^{7}$

To be sure, not all legislative initiative inevitably comes from the top. Nonetheless, a legislative proposal "remains a mere idea until it has been taken over by the appropriate party agency" (loffe, p. 36). Only after such an agency approves a legislative draft is it possible to proceed to formal enactment.

Even in the implementation of new legislation, or of laws already on the books, a state agency may turn to its party supervisor for guidance. For example, when a technical dispute arose within an important state commission during the mid-1970's, the chairman deferred taking a decision on the matter-even though the majority on the commission supported him - by saying: "Let's hold off on the decision and find out what our [party] curator thinks." ${ }^{8}$ Conversely, in 1978, when scholars of the Institute of State and Law of the Academy of Sciences initiated a purely theoretical discussion of legislation to implement Article 58 of the new Constitution, which presumably guarantees a citizen the right to judicial redress for unlawful violation of his rights by an official, they were told to cease and desist. To date, Article 58 remains a dead letter (loffe, pp. 37, 52).

Party leaders not only control the flow and implementation of legislation, they also frequently adopt a cavalier attitude toward their own laws. The Politburo, which has historically defined itself as a meta-juridical institution above and outside the law it creates, routinely bypasses budget law, for example, in order to procure funding for unforeseen exigencies, and it regularly orders or permits ad hoc amendments to planning law in order to overcome unexpected difficulties. In neither case does the party bother to use the established legislative process to carry out such changes in an orderly way. In effect, "the annual planning laws remain intact, while the real plans are changed again and again in a tightly closed administrative sphere without any needless publicity" (loffe, p. 218). Typical of this approach to planning law is the example of Aleksey Kosygin, who when informed in the late 1970's that oil output had declined because of, among other things, new, general restructuring legislation that stripped the industry's enterprises of their status as juridical persons, exclaimed: "Well, then, to hell with the restructuring. Consider them juridical persons!"9 In brief, Soviet politics of law are characterized by "strict legality" in the texts and "striking arbitrariness" in practice (loffe, $p$. 182).

THE PARTY MAINTAINS its control over the administration of criminal and civil justice, and the policyimplementation process in general, by means of a steady flow of directives to the operational agencies involved. These party directives, described variously as "instructive law" (Neznansky, p. 30) or "secret instructions," (loffe, pp. 38, $57,164)$, constitute a considerable body of classified, unpublished rules. Formal legal norms - constitutional, code, and statutory law-

\footnotetext{
'See Konstantin M. Simis, "The Making of the New Soviet Constitution: Conflict over Administrative Justice," In Robert Sharlet, Ed., "Studies in Soviet Legal Policymaking and Implementation," a special issue of Soviet Union, (Tempe, AZ) Vol. 6, No. 2, 1979, pp. 203-07. Simis, a former Soviet jurist, was involved in the drafting of the 1977 Constitution before his emigration from the USSR.

- Olimpiad S. loffe, "Law and Economy in the USSR," Harvard Law Review (Cambridge, MA) May 1982, p. 1605.

- iotfe, "Law and Economy. ...," pp. 1623-24.
} 
are constantly subject to interpretation through the prism of party instructions. In effect, "instructive law is a hidden reef that underlies the Soviet system of justice" (and administration), which an official can ignore only at his own peril (Neznansky, p. 32).

In the sphere of criminal justice, instructive law affords party officials and appointees - in a word, the ruling class - "the protection of the law denied to the ordinary citizen" (Neznansky, p. 39 ). ${ }^{10}$ In practice, a protected individual suspected of a crime cannot be arrested without party sanction, and often investigations are impeded, criminal proceedings terminated, or punishment limited to disciplinary action by the party. The higher the rank of the individual, the less likely it is that he will face any formal juridical action, and the more likely it becomes that he will be dealt with on a purely intra-party basis. A recent example was the case of Nikolay A. Shchëlokov, long-time USSR Minister of Internal Affairs under Brezhnev. Reportedly involved in a bribery scandal, Shchëlokov was dismissed from office shortly after Andropov's rise to power and the initiation of an anti-corruption campaign. The errant minister was subsequently subjected to party sanctions, but no legal action was initiated against him (loffe, p. 199). ${ }^{11}$

Lesser party officials and nomenklatura appointees accused of economic crimes also frequently escape prison as a result of par-

\footnotetext{
' See also loffe, Soviet Law and Soviet Reality, p. 143 , especially the "Romanov case," in which party permission to arrest a prominent person suspected of a crime was denied.

"On the anti-corruption campaign, see Robert Sharlet, "Soviet Legal Policy under Andropov: Law and Discipline," in Joseph L. Nogee, Ed., Soviet Politics: Russia After Brezhnev, New York, Praeger, 1985, pp. 85-106; and on corruption in general, see Konstantin M. Simis, USSR: The Corrupt Society, New York, Simon and Schuster, 1982
}

ty intervention. In the early 1960's, for example, Ivan Satin, a local party official, was caught operating a large-scale fruit and vegetable scam in the Moscow region. His illegal organization included several dozen well-placed individuals in the political, legal, and economic apparatus. The scam involved diverting produce from state warehouses for under-the-counter sale in retail outlets. The annual take was over 500,000 rubles. Although the Procuracy had a solid case, the party would not permit the arrest of several ringleaders, including the first secretary of a district party committee and the chairman of the executive committee of the local soviet. Satin himself received only a light sentence, while 30 of his lower ranking accomplices were sentenced to terms of 10 to 15 years (Neznansky, pp. 104-07). ${ }^{12}$

In another case, in the mid1960's, the jilted mistress of a senior gas-industry official anonymously denounced her former lover for running an extensive extortion and kickback racket among his employees. The operation included discreet payoffs in the form of valuable presents to two ministers and, through them, to Chairman of the USSR Council of Ministers Kosygin, who was, apparently unaware of the scheme.

Generally, Soviet criminal investigators approach a case involving highly placed individuals with considerable trepidation (Neznansky, p. 99). In this particular instance, the Moscow City procurator warned his subordinate that the ministers would probably invoke their party connections. It did not matter that an airtight case could be made. The Central Committee refused to

${ }^{12}$ On this type of case in general, see Gregory Grossman, "The 'Second Economy' of the USSR," Problems of Communism (Washington, DC), September-October 1977, pp. 25-40. condone the arrest of the ringleader, and the Administrative Organs Department instructed the Procuracy to terminate criminal proceedings against all those involved for "lack of evidence." In the end, the chief investigator in the case was dismissed on the grounds that he had brought charges against the notables prematurely (Neznansky, pp. 107-11). ${ }^{13}$

Another example of party interference in a criminal case involved the editor of the magazine Ogonek, A. Sofronov, who was reported by his employees for embezzling large sums of money in the mid1970's. The evidence was irrefutable, but because Sofronov was involved in disseminating the party's ideological line, Mikhail Suslov intervened on his behalf, and the "case took another course." In the subsequent cover-up, not only did the editor avoid punishment, but those who had turned him in were brought to trial (loffe, p. 199).

Party instructions also orchestrate all political cases. As one regional party official noted candidly to a roomful of judges: "Yes, you judges are independent and subordinate only to law. But you are dependent on me, are you not?" (loffe, p. 220). Further indication of party involvement in political trials can be found in the samizdat literature that reaches the West. It is replete with accounts of political cases decided according to party directives, which emanate more often than not from an anonymous apparatchik. ${ }^{14}$ Investigator Neznansky cites a more unusual

\footnotetext{
${ }^{13}$ For a similar case, the so-called Uzbek fur case, see loffe, Soviet Law and Soviet Reality, pp. 105-06. 14 For an analysis of such cases, see Robert Sharlet, "The Communist Party and the Administration of Justice in the USSR," in Donald D. Barry. F.J.M. Feldbrugge, George Ginsburgs, and Peter B. Maggs, Eds., Soviet Law After Stalin, Vol. III: Soviet Institutions and the Administration of Law, Alphen aan den Rijn, The Netherlands, Sijthoff end Noordhof, 1979, pp. 321-92.
} 
example - a classified case of internal dissent assigned to him in the late 1960's. It concerned two Greek Communists who had emigrated to the Soviet Union several years earlier, but had since become disillusioned and were seek. ing to leave the USSR. In the case file, Neznansky found General Secretary Brezhnev's "personal instructions" to press charges against the men for contacting the Chinese ambassador about re-emigrating to the People's Republic of China (p. 35).

The party also intervenes in routine criminal cases, but on a more selective basis, and in less dramatic ways. One such instance was a 1978 case of attempted rape cited by loffe. The victim, a young Leningrad woman, was rescued by fellow citizens, who turned her attacker over to the police. The assailant did not deny his crime, and it looked like an open-and-shut case. His father, however, was a prominent law professor at Leningrad University - to be precise, the chairman of the Criminal Law Department. The professor used his professional connections to have the case terminated on a technicality, no doubt with prior approval from the appropriate party organ (p. 200). ${ }^{15}$

Party influence can serve not only as a mitigating factor for those who fall under its protection, but also as an aggravating circumstance for the less fortunate. Such was the experience of a Moscow factory worker in a case described by Neznansky. The man committed a minor offense (petty theft), but was given a harsh sentence out of all proportion to the crime. It

${ }^{15}$ For a rape-murder case involving party pressure in the opposite direction-to get a conviction at any costsee the "Case of the Two Boys," in Dina Kaminskaya, Final Judgment: My Life as a Soviet Defense Attorney, New York, Simon and Schuster, 1982, Part Two. seems that it was his bad luck to have had his case adjudicated during a special party-sponsored lawand-order campaign designed to clean up Moscow before the 1980 Summer Olympic Games. Moscow City Party Committee First Secretary and Politburo member Viktor Grishin had warned prosecutors and judges that "he would personally look into any cases" in which lenient sentences were handed down (p. 36). ${ }^{16}$

As in any legal system, the vast majority of cases that arise in the Soviet Union involve civil litigation of one kind or another. In this area, too, the influence of the party is often felt, as indicated by the following:

- In a series of civil suits, bus drivers in Leningrad sought compensation from management for carbon monoxide poisoning due to faulty maintenance of vehicles and hazardous working conditions. Before the local authorities realized how many drivers had been poisoned, the first few cases sailed through the courts in favor of the plaintiffs. Faced, however, with hundreds of similar compensation claims, the party stepped in with a secret directive forbidding any further decisions against the management. Defense arguments thereafter fell on deaf ears, and all subsequent appeals failed as party instructions overrode civil equity. ${ }^{17}$

- An enterprise counsel in Ukraine believed that the local arbitration board had acted illegally

is Similarly, see also the "Uzbek black marketeer case," pp. 88-89. In spite of blatant procedural error, all appeals failed in face of an ongoing party campaign. As a senior procurator bluntly put it: "'The party won't understand our overturning verdicts just because some procedural rule was broken."

${ }^{17}$ See Yuri Luryi, "Soviet Labor Law: New Concepts or Relationships?" Columbia Journal of Transnational Law (New York), vol. 23, No. 2, 1985, pp. 423-24. The author was formerly a defense attorney at the Leningrad bar in rejecting his claim against a rail freight carrier. He later learned that "all arbitrators are under a firm party order not to penalize the railroads" in economic disputes (Shelley, pp. 63-64).

- A regional party committee secretly sanctioned an illegal decision on housing legislation by a city soviet. A group of law professors asked the city prosecutor to appeal the decision in the manner provided for by Soviet law. Knowing that the party had a hand in the matter, the wary prosecutor declined to act (loffe, p. 42).

- An arbitration board imposed a very heavy fine on an enterprise for failing to fulfill its planned contractual obligation to a trading partner. The director of the organization "appealed" to the regional party committee, arguing that his preoccupation with fulfilling a military order had overridden the obligation in question. The party, in keeping with its standing policy of bailing out priority industries (such as the railroads and the defense sector) when management problems arise, interceded and directed the chief arbitrator to set the case aside (Shelley, p. 72).

- In a clearcut probate case, the party issued "secret instructions" to a lower court to resolve a dispute between the heirs of a famous physician in a manner that contravened the laws of inheritance. On appeal, the higher courts implicitly deferred to the instructive law and upheld the illegal decision (loffe, p. 191).

POLITICAL LICENSE and "legalized arbitrariness" are most blatant in Soviet administrative law. As loffe points out, "most administrative regulations are not only unpublished but even secret [i.e., classified]. Therefore, citizens who have been ordered administratively to do or not to do something cannot 
check the legality of the orders received" (p. 205). Given the sub rosa character of administrative rules, the opportunities for covert party manipulation are legion. In effect, party instructive law can virtually reshape administrative regulations at will. Two examples involving university admissions policies will suffice to illustrate this point.

In the mid-1960's, the Kirghiz Party Central Committee directed the republic's university to implement a kind of affirmative-action program to increase the enrollment of native women. Contrary to formal Soviet university procedure, female Kirghiz students were to be admitted without having to take the entrance examinations required of all other applicants, including young women of other nationalities resident in the republic. In fact, however, examinations were a mere formality, notes loffe, since all the vacancies had been allocated beforehand to the children of the ruling elite "according to various secret instructions" (pp. 42-43, 214-15). A decade later, in the mid-1970's, the Leningrad regional party organization issued secret instructions mandating a discriminatory admissions policy at Leningrad University, by ordering certain faculties, including law, not to admit "Jews, half-Jews, or persons who looked Jewish" (loffe, p. 39). ${ }^{18}$

THE INSIDE VIEW of the Soviet legal system offered by former Soviet jurists clearly illustrates the strong impact of politics on Soviet law and supports the generally ac-

t8 On the method of rigging entrance exams for the purpose of discriminating against Jewish applicants to Soviet universities, see Grigori Freiman, it Seems I Am a Jew: A Samizdat Essay, trans. by M. B. Nathanson, Carbondale, IL. Southern Illinois University Press, 1980. esp. Ch. 3. The author writes about his experiences as a Soviet mathematics professor. cepted Western scholarly perception of the interrelationship between the party and law in the USSR. ${ }^{19}$ It demonstrates that in its penchant for intervening directly in the legal process on behalf of its cadres and apparatchiki or in defense of significant regime interests, the party actually practices the "jurisprudence of political expedience." 20

Yet, despite this evidence of actions to the contrary, the party continues to preach a doctrine of strict legality, and Soviet juridical literature describes the relationship between the legal system and the party in a rather sanitized form. Witness, for instance, the commentary by Central Committee official Boris Ponomarëv concerning the Constitution's assertion that "all party organizations operate within the framework of the USSR Constitution":

The proposition set forth in paragraph 3 of Article 6 means that the party organizations in the first place shall not replace state organs, and secondly shall not violate the Constitution and legislative acts enacted in accordance with it. The central party organs may, of course, find it necessary to introduce changes and additional provisions into legislation and issue corresponding statements to this effect addressed to deputies of the Supreme Soviets - to communists, and to communists who work in the highest state organs, but until the law has been altered or abrogated, all party organizations must conform to it. The principles of social-

- John Hazard probably speaks for most specialists on Soviet law when he writes: "Politics run like a red thread through the institutions of Soviet law . . .," Managing Change, p. 12.

20 Robert Sharlet, "Varieties of Dissent and Regularities of Repression in the European Communist States," in Jane L. Curry. Ed., Dissent in Eastern Europe, New York, Praeger, 1983, esp. pp. 12-14. ist legality, consequently, extend fully to the Communist Party. ${ }^{21}$

Similarly, with regard to the implementation of law, the party modestly acknowledges its mandated general supervisory role without ever hinting at its actual ad hoc interference in individual cases. For instance, as noted in the mid-1970's by one party official in the USSR Ministry of Justice, "the Party Bureau of the Ministry and the party organizations of the administrations and of departments direct the work of communists, of all collaborators in further perfection of the organization of work of the [legal] apparatus, strengthening work discipline, improving auditing and verification of the execution of policy, and raising the personal responsibility of every worker for the work assigned" (The Soviet Legal System, pp. 39-42). ${ }^{22}$

To be sure, the party usually does confine itself to a supervisory role over legal institutions. To do otherwise would be impractical and would leave its "leading role" in the Soviet system in shambles, since direct intervention in specific cases can be very time-consuming for party officials and organizations already burdened with manifold other responsibilities. Thus, line party organizations generally seek to exercise control by setting the broad policy parameters within which legal institutions operate, while staff party committees in those institutions strive to ensure general compliance.

21 Hazard, Butler, and Maggs, The Soviet Legal System, p. 36; the volume provides a compilation and translation of useful selections of laws and commentaries on all aspects of the Soviet legal process. For some additional discussion of Art. 6, see also loffe, Soviet Law and Soviet Reality, p. 202.

2 For an analysis of supervision as opposed to interference in the party reiationship to the Soviet legal system, see R. Sharlet. "The Communist Party and the Administration of Justice in the USSR." loc. cit., esp. pp. $338-80$. 
As a result, in the great majority of instances involving neither a protected person nor a pressing political priority, Neznansky observes, "justice for the ordinary citizen in the USSR has lost much of the arbitrariness of the Stalin era and is most closely determined by the objective standards of formal law" (p. 39). Soviet legal literature abounds in cases in which the post-Stalin rules of due process for both criminal and civil cases have been maintained and/or enforced through higher court review (The Soviet Legal System, Chs. 7 and 8).

Moreover, in most of the disputes that parties choose to bring to state arbitration, Louise Shelley's respondents report, state arbitrators carry out their duties with a high degree of legal professionalism (pp. 49-52, 69-71). ${ }^{23}$ However, while the state arbitrator's decisions are usually based on objective legal criteria, they are frequently difficult to execute due to, among other things, the rigidities of the centrally planned Soviet economy. Thus, in practice-as a means of coping with the structural defects in the economic system-enterprise directors often avoid the legal process by resorting to "informal rules," a "set of mores [or] unwritten laws" that have evolved in the interstices between the party's instructive law and the formal law of the state (Neznansky, p. 37).

IN THE BOOKS reviewed here, some broader perspectives on the interplay between politics and law in the Soviet Union are presented by John Hazard, long the doyen of Soviet legal studies in the West, and by Olimpiad loffe, for many years the preeminent civil law specialist in the USSR. Although their

${ }^{23}$ See also Hazard, Butler and Maggs, The Soviet Legal System, Ch. 14. vantage points are different $-\mathrm{Haz}-$ ard writing as an informed and experiënced Western observer and loffe as a former practitioner of Soviet law - their views coincide on three fundamental issues.

First, both are in agreement on the dominant role of the party in the Soviet system in general, and in the legal system in particular. As Hazard has noted: "The conclusion cannot be avoided that, if there is any principle that communists hold sacred and which they will defend at all costs, it is the Communist Party's monopoly rule" (Managing Change, p. 11). Second, both agree that the party has come increasingly to rely on law as a means of control and governance, steadily bringing more and more relationships and activities within the purview of the country's legal codes. In loffe's words: "Year after year legal regulations are becoming more and more widespread in the country" (p. 16). ${ }^{24}$

Third, Hazard and loffe are in accord on the existence of significant gaps between reality and law in the USSR. Hazard notes a major disjunction in looking back over the span of Soviet legal history:

The communists of 1917 promised much: abundance; social tranquility; a society that would require no coercion; international proletarian brotherhood; a legal system that would favor the working man and eventually wither away, to be replaced by a non-coercive set of administrative regulations and a thoroughly absorbed sense of social obligation that would stimulate citizens to perform duties because they understood their importance to community well-being. None of

\footnotetext{
24 See also Robert Sharlet, "Constitutional Implementation and the Juridicization of the Soviet System," in Donald R. Kelley, Ed., Soviet Politics in the Brezhnev Era. New York. Praeger, 1980, pp. 200-234.
}

this has been achieved in the sixtyodd years of Soviet history. Production has lagged; productivity has been low; conflict exists in society; deviance is punished severely; the legal system has been developed along conventional Romanist lines; administrative regulations have multiplied, to be enforced with coercive measures; and laws have had to punish "parasites" for refusing to work and nonconformists for departing from the principles established by the Communist Party in its Code of Morals. (Managing Change, p. 169)

For his part, loffe has in view primarily the period since Stalin, in which he sees a series of profound contradictions between the theory and the practice of Soviet law.

ment over the function of law and the role of the jurist in the Soviet system. These differences are further magnified by the fact that loffe is drawing on past experience while Hazard is looking to the future.

For loffe, Soviet law is essentially a relatively static order-maintenance system aimed at maximizing the party's power over society and protecting the "state's position of economic monopolist" (p. 13). $\mathrm{He}$ repeatedly uses the metaphor of the mask, describing Soviet law as "legislative camouflage" or "a disguising mask" that serves as a "practical cover for arbitrariness" (pp. $85,177,218$ ). The pervasive image is one of law as a shroud stifling political and economic initiative that does not conform to prescribed party norms.

For Hazard, Soviet law is primarily a dynamic instrument in the party's hands for shaping the socioeconomic environment and moulding the Soviet citizen in the desired image. The dominant 
theme of Hazard's past work has been the linkage between law and social change in the USSR and in Soviet-type systems. ${ }^{25}$ As he contemplates the future development of the Soviet system, the prevailing image is one of jurisprudence as a policy science for "managing change" through "the orderly procedures of law" (Managing Change, p. 47).

As one might expect, loffe's and Hazard's divergent conceptions of Soviet law rest on very different perceptions of political and economic reality in the USSR. To loffe, the "appropriate criterion" for economic efficiency is the degree to which the present economic structure sustains the political dominance of the state, and not the degree to which it ensures the material well-being of society. From this point of view, he argues, the party "leadership has made the economy work splendidly as the source of its dictatorship." loffe concludes that, given the nature of the Soviet political system, there is no hope that law could serve as a regulatory agent for reforming the economy without weakening state power. ${ }^{26}$

25 See John N. Hazard, Law and Social Change in the USSR, London, Stevens, 1953; and Hazard. Communists and Their Law, Chicago, University of Chicago Press, 1969.

26 See loffe, "Law and Economy in the USSR," loc. cit., pp. 1624-25.
For Hazard, the situation in the contemporary USSR presents a very different picture. In his view, the hegemonic role of the party in the Soviet system is being eroded as a consequence of the modernization of Soviet society. The party is no longer firmly in control of the course of events as the USSR approaches the slippery downslope to the "post-industrial era" with its unforeseeable problems. The Polish crisis, triggered by a failure to meet consumer needs, is recognized by Soviet leaders as a possible harbinger of a general crisis of state socialism, and they are haunted by the "spectre of unmanageable change" (Managing Change, p. 1).

In Hazard's opinion, the road to salvation for the USSR lies in the ongoing "scientific and technological revolution," which in turn must be accompanied by managerial innovation, beginning with "rethinking the unthinkable" - the role and methods "of the Communist Party itself." He suggests that the Soviet leadership may be on the threshold of enhancing the "politico-legal" role of the legally educated party member working alongside the economist and the engineer in managing the inevitable process of change (Managing Change, p. 43). ${ }^{27}$

Ultimately, of course, Gorbachëv (himself a lawyer-politician, as was Lenin) will determine which vision of Soviet law will prevail loffe's pessimistic forecast, or Hazard's optimistic scenario. Over 20 years ago, a prominent Soviet law professor suggested that lawyers could be of help in the legislative process, but only if they were "brave enough to say 'no' when necessary." The proposal had little impact then on the party's legal policy, and it cost the professor his position (loffe, p. 171). Will it be any different now under Gorbachëv? Will jurists play a significant role in shaping the Soviet future, or will they continue to simply carry out party instructions? The safe bet would be to await the implementation of the resolutions adopted at the 27th CPSU Congress (to be held in February 1986) before venturing any answers to such questions. Yet, if past experience is any guide, odds are that many years will pass before legality overcomes political expediency in the Soviet Union.

${ }^{27}$ See also $\mathrm{Ch} .4$ in passing. The Soviet legal press has been relatively silent since Gorbacherv's accession about what future role the jurist might play. Supportive of Hazard's projection is a recent lead article "Juridical Science: Planning, Multi-faceted Approaches, and Integration," Sovetskoye gosudarstvo i pravo (Moscow). August 1985, pp. 3-12. On the parts to be played by Soviet law and jurists in the scientific-technical revolution, see Robert Sharlet "STR, Party Policy, and Socialist Law, " in Gordon B. Smith, Peter B. Maggs, and George Ginsburgs, Eds., Soviet and East European Law and the Scientific-Technical Revolution, New York, Pergamon, 1981, pp. 47-77. 


\section{Last Stages of Leninism}

\section{Melvin Croan}

ALAIN BESANÇON. The Rise of the Gulag: Intellectual Origins of Leninism. New York, The Continuum Publishing Corporation, 1981.

GUY HERMET, Ed. Totalitarismes. Paris, Economica, 1984.

CARL A. LINDEN. The Soviet Party-State: The Politics of Ideocratic Despotism. New York, Praeger Publishers, 1983.

ERIK P. HOFFMANN and ROBBIN F. LAIRD. Technocratic Socialism: The Soviet Union in the Advanced Industrial Era.

AN OLD SAYING has it that whoever is incapable of change lacks the means of self-preservation. This adage applies not only to individuals, but to countries as well. The Soviet Union today stands at a crossroads where the very survival of its system may be at stake because recent leaders have failed to deal with the most basic problem facing the Soviet Union - the chal-

Melvin Croan is Professor of Political Science, University of Wisconsin (Madison) and author of numerous works on the Soviet Union and Eastern Europe, with a particular emphasis on East Germany. He is currently working on a study of bureaucratic socialism and its critics.
Durham, NC, Duke University Press, 1985.

STEPHEN F. COHEN. Sovieticus: American Perceptions and Soviet Realities. New York and London, Norton, 1985.

STEPHEN F. COHEN. Rethinking

the Soviet Experience: Politics and History Since 1917. New York, Oxford University Press, 1985.

TIMOTHY J. COLTON. The Dilemma of Reform in the Soviet Union. New York, Council on Foreign Relations, 1984.

lenge of change. Will Mikhail Gorbachëv put the USSR on the road to change? How far will it be able to move forward in the face of formidable institutional and ideological obstacles?

The volumes under review here deal with many different aspects of the Soviet experience. Yet all of them can be read with an eye to the conundrum of change. Furthermore, in one way or another, each study broaches the crucial question of the future of MarxismLeninism - the system's ideological lodestar - or, to put the accent where it rightly belongs, the future of Leninism.

ALAIN BESANÇON, a French specialist on Russian history, sees Leninism as virtually synonymous with the Soviet system, and as an amalgam of corrupt philosophy and debased religion, now permanently wed to the colossus of power it called forth. Although he devotes many chapters in his The Rise of the Gulag to unearthing the Russian roots of Leninism, Besançon is insistent that Leninism has to be understood as a chiliastic ideology, whose origins can be traced back to Gnosticism and Manichaeism and whose pretensions remain truly universalistic. Comparing the development of ideology to the different stages of the growth of parasites, he treats Leninism as the outgrowth of an inchoate French cycle and a more developed German cycle, the latter involving successive mutations of Hegelianism by Marx and Engels. Leninism for him is the final mutation of all of its antecedents and constitutes a complete ideology unto itself. The clear implication is that Leninism as an ideology has little in common with Russian national traditions. Yet, it took root because "civil society in Russia suffered, with regard to the state, from a congenital weakness," writes Besançon, and because the cultural environment was not sufficiently varied, vigorous, and diverse "to combat and eliminate" this ideology, as occurred in France and Germany. For Besancon, this explains why "neither in France nor in Germany could an 
ideology have been established as simple, as complete, as fortified and as organized as the Russian ideology" (pp. 105 and 104). Besançon's view of Leninism as alien to Russian national traditions is similar to that of Alexander Solzhenitsyn, whom Besançon admires as an exemplar of the virtue of pure truth which, he firmly believes, must eventually prevail over ideological falsehood.

According to Besançon, Leninism presently holds sway not because it conveys conviction, but because it manifests power. As he puts it, "All the reality of ideology is concentrated in the exercise of power" (p. 289). Yet, precisely because this is true of Leninism, the Soviet system is incapable of change and, Besançon concludes, is doomed to immobilism and destined to be swept away by an evolving reality that Leninism cannot even begin to comprehend.

In many respects, Besançon's treatment of Leninism as an ideology intermeshed with power is bound to call to mind Hannah Arendt's classic study, The Origins of Totalitarianism, a veritable tour de force that related the pursuit and exercise of unlimited power to considerations of intellectual history, social decay, economic dislocation, and, above all else, abnormal political psychology. Arendt held the "essence" of totalitarianism to be terror, prefigured by the relentless compulsion to impose the fictitious world of ideology upon a recalcitrant reality. Her work - indeed, the notion of totalitarianism itse $1 f$ - received much criticism from various quarters. Many political scientists, and some historians, contended that theories of totalitarianism could not be "operationalized," and that they served to obfuscate, rather than to clarify the actual experiences of the regimes that they were suppos- ed to explain. What the critics overlooked was that the concept of totalitarianism constituted less a tool for empirical micro-analysis than an expression of moral concern in the grand tradition of political philosophy.

This and many other important points are cogently argued by Pierre Hassner in his insightful contribution ("Totalitarianism Viewed From the West") to the volume on "totalitarianisms" (note the plura|]), edited by Guy Hermet. The publication of this book in Paris at a time when controversies about the concept of totalitarianism have all but subsided in the Anglo-Saxon world ${ }^{1}$ is itself noteworthy as a manifestation of the dramatic shift of Left Bank intellectual attitudes away from an earlier enchantment with Sovietstyle socialism. The greater the pity, therefore, that the chapter on the Soviet Union, written by Aleksander Smolar, should have largely failed to answer the question, "transformation or degeneration?" posed by its title. ${ }^{2}$ However, in general, the volume sustains a fairly high standard of analysis; in addition to Hassner's excellent presentation, and two brief but thoughtful epilogues authored by Juan Linz and Richard Lowenthal (two non-French students of the subject), special mention should be made of Pierre Manent's contribution, "Totalitarianism and the Problem of Political Representa-

'For a recent discussion of these controversies, see Walter Laqueur, "Is There Now, or Has There Ever Been, Such a Thing as Totalitarianism?' Commentary (New York). October 1985, pp. 29-35.

${ }^{2}$ Long-time readers of this journal will recognize the title as having been borrowed from Zbigniew Brzezinski's article. "The Soviet Political System: Transformation or Degeneration?" Problems of Communism (Washington. DC), January-February 1966. Brzezinski's essay was reprinted along with the commentaries that it engendered in Zbigniew Brzezinski, Ed., Dilemmas of Change in Soviet Politics, New York, Columbia University Press, 1969. tion." Exploring the political theory of representation in terms of the relationship between civil society and the state, Manent's rich, dialectical discussion adds true philosophical depth to the subject of the state's absorption of civil society, considered by most contributors to this volume to be the hallmark of totalitarianism.

IN HIS BOOK, The Soviet PartyState, Carl Linden, who previously proposed a "conflict model" of Soviet politics in lieu of the totalitarian approach, ${ }^{3}$ returns to the fray with the concept of "ideocratic despotism." Borrowed-with due acknowledgement - from Nicholas Berdayev, the term "ideocratic" is meant to convey the primacy of ideology, "a secular analogue to theocracy with its close tying of ideas as dogma and power" (p. xii) In the ensuing discussion, Linden stresses the Leninist input, but he also feels that original Marxism must be regarded as "an active, not inert, ingredient in the political chemistry that produced the first ideocratic party state" (p. $x$ and $C h$. 1). This Soviet party-state, according to Linden, claims to be monolithic, but it actually suffers from the factional politics that Linden deems to be inherent in ideocratic rule.

Soviet "crypto-politics," to use T.H. Rigby's apt designation, ${ }^{4}$ has produced few real heroes, yet Linden comes close to treating Nikita Khrushchëv as one. Despite the many contradictions in the policies of this former Soviet leader, Linden gives him relatively high marks for at least attempting to ameliorate despotism, and for

\footnotetext{
- Cari A. Linden, Khrushchev and the Soviet Leadership. 1957-1964. Baltimore, The Johns Hopkins Press, 1966, pp. 1-9.

"T.H. Rigby, "Crypto-Politics," in Frederic J. Fleron, Jr., Ed., Communist Studies and the Social Sciences, Chicago. Rand MCNally, 1969, pp. 116-28.
} 
shifting "the party's focus from ideocratic to mundane economic managerial functions" (p. xi and Ch. 5). By contrast, he judges Leonid Brezhnev to have strengthened the coercive and repressive features of the Soviet system, with the objective of reimposing a purely despotic relationship between the rulers and the ruled. Yet, as Linden makes clear in his tantalizing-if rather disjointed-discussion of "repressed political potentials" (Ch. 4), he believes that the regime's ideocratic foundations will be subject to an ever-increasing challenge from below, especially from various Russian nationalist currents. "In the not distant future," Linden writes, the Soviet leadership will have to confront a stark choice between instituting "a basic change in its manner of rule" or else risking "an upheaval" (p. 158).

HOW THE KREMLIN has sought to obviate such unpalatable alternatives is the subject of Technocratic Socialism, coauthored by Erik Hoffmann and Robbin Laird. This study, the final volume in a trilogy, ${ }^{5}$ presents a comprehensive summation of recent Soviet thinking on policy-making, politics, and progress under conditions of advanced industrialism. The authors argue that the concept of "developed" or "mature" socialism, unveiled under Brezhnev, together with various corollary constructs involving "the scientific-technological revolution" and "the scientific management of society," comprise a distinct, Soviet ideology of advanced modernization and, therefore, signify a pragmatic adapta-

${ }^{5}$ The two earlier volumes were The Politics of Economic Modernization in the Soviet Union, Ithaca, NY, Cornell University Press, 1982; and The ScientificTechnological Revolution and Soviet Foreign Policy, Elmsford, NY, Pergamon Press, 1982. tion of official Marxism-Leninism. At the same time, they emphasize that the new, authoritarian order, which they designate as "technocratic socialism," constitutes an orientation of the top elite that has yet to become "an integral part of bureaucratic behavior or mass political culture" (p. 198). This elite, according to the evidence so assiduously marshalled by Hoffmann and Laird, has always harbored deep-seated reservations about opening up decision-making processes to anything resembling real participation by the lower echelons. Therefore, the authors' attempt to sift through official pronouncements so as to pinpoint conservative, reformist, and centrist positions within the elite seems contrived. Moreover, it also tends to deflect attention away from one of their more basic points, namely, that the primary objective of Soviet theorizing thus far has been to devise more effective means for formulating and im. plementing policy from the top down, and for fashioning more streamlined methods of political control over society.

TO TURN FROM Hoffmann and Laird's highly informative-but ultimately inconclusive-study to Stephen Cohen's two recent books is to experience initial delight that quickly turns to distress. Both Sovieticus, a collection of topical commentaries that appeared in The Nation magazine, and Rethinking the Soviet Experience, a more substantial academic disquisition, are written with sustained verve. Each is predicated upon the commendable supposition that politics and history comprise a single subject of study. Unfortunately, both the historical interpretations Cohen ventures and the political arguments he advances turn out to be seriously flawed.
Introducing himself as a revisionist among Sovietologists, Cohen proceeds to attack most of the "conventional wisdom" of preeminent scholars in the field. He indicts the Western-and, particularly, the American - scholarly perception of the Soviet system. This does not mean that he holds any brief for the Soviet system, at least not for the form that it has taken since Stalin's rise to power. Yet, while Cohen sees the evident defects of the system, he seems to believe that just about everything objectionable about the Soviet experience can be blamed on the West. What he fails to acknowledge is that absolving the Soviet regime of virtually all responsibility for its conduct at home and abroad is, as Richard Pipes has suggested, tantamount to holding Russia itself in deep contempt. ${ }^{6}$

What is the course Soviet history might have taken had the West shown the Soviet Union a full measure of "understanding"? Cohen, who is also the author of a highly sympathetic biography of Nikolay Bukharin,? consistently argues the possibility of a nonStalinist alternative. His mighthave-been scenario centers on the blossoming of the New Economic Policy (NEP, 1921-28) which allegedly Bukharin would have championed and nurtured until it had developed into something approximating full-scale market socialism with a human face. This historical fantasy has to be predicated either on the view that Leninism is substantially more open-ended and open-minded than the burden of the available

- Richard Pipes, "U.S. and Them," The New Republic (Washington, DC), Oct. 14, 1985, p. 34. For Cohen's rejoinder to Pipes, which seems to sidestep Pipes's point about holding Russia "in deep contempt," see his letter, "Cohen on Pipes," ibid., Feb. 3, 1986, p. 42

'Stephen F. Cohen, Bukharin and the Bo/shevik Revolution: A Political Biography, 1888-1938. New York, Alfred Knopf, 1973. 
evidence allows us to believe, or else on the contention that "Bolshevism was larger and more diverse than Lenin and Leninism" (Rethinking the Soviet Experience, p. 49).

But what would a non-Leninist type of Bolshevism really amount to, if not a blatant contradiction in terms? And even if one were, for argument's sake, to deem such a concoction feasible, would it have been politically viable? Furthermore, would Bukharin necessarily have been the right person to lead the experiment? Finally, would a Bukharinite Soviet Russia have inexorably progressed toward the democratic, yet developmental, socialism of Cohen's imagination? These are all questions that the author has studiously avoided because, given the nature of the case, they are unanswerable.

Cohen is deliberately equivocal with regard to the prospects for change in the contemporary Soviet system. On the one hand, he envisions the emergence of a "coalition for change" composed of both reformers and conservatives within the ruling elite. In his view, this coalition would draw strength from many sources, including the official ideology's promise of a better future, and its commitment to "the very idea, desirability, and inexorability of change" (Rethinking the Soviet Experience, p. 152). Lest anyone suppose that such an ostensibly significant asset could assure the triumph of reformism, Cohen - consistent to the very end - protests that reform will be a lost cause unless the West adopts conciliatory policies toward the Soviet Union. This, of course, is neither self-evident nor demonstrable. In fact, competitive East-West relations, including perhaps the tensions and crises Cohen so decries, could well prove to be a much greater incentive to Soviet domestic reform than the détente he advocates. In any event, it would be foolhearty for the West to sacrifice its own legitimate interests for a chimerical pursuit of domestic change in the Soviet Union over which, pace Professor Cohen, it can never hope to exert decisive influence.

A MUCH MORE SOPHISTICATED approach to the basic issues of change in the Soviet system is provided by Timothy Colton in The Dilemma of Reform in the Soviet Union. This thought-provoking, short book, conceived as an "essay" for a "general audience," manages to review the legacy of the Brezhnev period, diagnose the ailments of the Soviet system, examine the emergent ruling elite, explore various options for change, and consider the relationship between foreign affairs and domestic policy-all in a scant 100 pages. Though admirably concise, Colton's study is full of insights, and is so tightly argued throughout, that no brief summary can substitute for the actual reading of the text itself. Suffice it to note only that Colton foresees the Kremlin opting for a course of "moderate reform," which he defines as:

a strategy of controlled change somewhere between radical and minimal reform. Its focus would be on public policy and the machinery needed to fulfill change, not on basic institutions and beliefs. Hence it falls well short of radical reform. But, unlike minimal reform, the change involved will pose a challenge to some established groups and thereby generate controversy and conflict. (p. 63)

His prediction appears to be remarkably accurate. Having come to power after these words were written, the new Kremlin leadership headed by Gorbachëv seems bent on precisely the course charted by Colton. It remains to be seen whether the limited initiatives undertaken thus far by this leadership will lead to any wider ranging measures, and whether they will produce the desired results. Colton forecasts potentially dire consequences, should resurgent conservative forces obstruct change or, in his words, if "bungled reforms come to naught" (p. 79).

IS THE SOVIET UNION, then, on the verge of an existential crisis? Clearly Besançon and Linden, as well as other observers, feel that this may well be the case. ${ }^{8}$ Colton, for his part, alludes to the possibility of a "crisis of legitimacy" in the 1990 's in the event of a miscarriage of "moderate reform," but rejects the thesis that the survival of the Soviet system is presently at stake, and cautions against an underestimation of the rulers' resources and an exaggeration of their problems. From his extensive, although by no means exhaustive, list of Soviet ailments, Colton singles out economic stagnation as the most likely source of serious trouble in the longer term. On the opposite side of the ledger, he notes such features as societal inertness, patriotic pride, and the like, calling special attention to the entrenched power of the ruling elite and the elaborate network of controls that it commands. "Although some controls can be modi-

- See, for example, Ernst Kux, "Contradictions in Soviet Socialism," Problems of Communism, NovemberDecember 1984, pp. 1-27; and R.V. Burks, "The Coming Crisis in the Soviet Union," in Morton A. Kaplan and Alexander Shtromas, Eds., The Prospects for Transformation in the Soviet Union, New York, Professors World Peace Academy, forthcoming. Burks argues that "the chances of system breakdown in the Soviet Union within the next five to ten years are probably better than even.' 
fied," he asserts, "no present or foreseeable Soviet leader will tamper with the basic authoritarian credo of Leninism" (p. 59)..$^{9}$

This is, in fact, precisely the rub. Viewed in retrospect, Leninism must surely be ranked as one of the most powerful and durable ideological/political forces of the 20 th century. As a technique for the seizure of power and the maintenance of control in backward areas of the world, it knows no rival. It is also unsurpassed in its proven ability to foster social mobilization and political institutionalization simultaneously, thereby escaping the kind of premature decay of power experienced by other revolutionary regimes. ${ }^{10}$ All told, it has proved remarkably successful in carrying through its own highly distinctive strategy of "politically forced development."1" But can this very same Leninism also adjust to the unintended consequences of what it has wrought? Can it cope effectively with the fundamental political challenges posed by novel developments that fall beyond the conceptual grasp of its parochial Weltanschauung? The odds against the requisite transmogrification of Leninist theory and practice appear well-nigh overwhelming.

Consider, in the first instance, Leninism's elitist conception of "democratic centralism" and the politics of administrative command

${ }^{9}$ Warning against wishful thinking in the West concerning Gorbachevv, the astute columnist, George F. Will, recently remarked that "any Soviet leader has been thoroughly marinated in the ideology that legitimates

him." "Abolishing the 20th Century," Newsweek (New York), Dec. 9, 1985, p. 104.

${ }^{10} \mathrm{~A}$ seminal analysis of these issues was first offered by Samuel P. Huntington, "Political Development and Political Decay," World Politics (Princeton, NJ), April, 1965, pp. 386-430.

"See Richard Lowenthal, "Development vs. Utopia in Communist Policy," in Chaimers Johnson, Ed., Change in Communist Systems, Stantord, Stanford University Press, 1970. to which it has given rise. The latter has spawned the nomenklatura, a monstrous labyrinth of preferment, patronage, and privilege. Its beneficiaries, now numbering close to several million persons, constitute something of a class unto themselves that manifests a highly developed sense of vested interest in self-preservation. ${ }^{12}$ It is one thing for Gorbachëv to replace top-ranking Brezhnevera gerontocrats, or to remove incompetent individuals along the line; it would be an entirely different matter for any Soviet leader to excise the entire bureaucratic excrescence. After all, the nomenklatura is a key factor contributing to the regime's stability, even though it is also a major component of systemic stasis.

Reforms that may eventually lead to a relaxation of controls in order to introduce some measure of genuine popular participation to say nothing of any broadly gauged marketization of the Soviet economy-pose a somewhat different, though related problem. As Linden reminds us, Leninism provides no "practical wisdom" about how to delimit, devolve, or distribute power. Indeed, all of its ingrained, antidemocratic reflexes, rooted in Lenin's profound distrust of the masses and reinforced by the Soviet party-state's jealous monopolization of the many perquisites of power, militate against the very possibility of such change. As if that were not enough, there remains the factor of the cultural

\footnotetext{
12 For an ex-insider's firsthand experience of the nomenklatura system, see Mikhail Voslensky, Nomenklatura: Gospodstryyushchiy klass Sovetskogo Soyuza, London, Overseas Publications, 1984. The recent translation into English of Voslensky's informative and insightful book, published by Doubleday as Nomenklatura: The Soviet Ruling Class, is from the German edition and contains numerous misrenderings of Soviet political terminology. See the discussion of Voslensky's book by Peter Reddaway, "More Equal Than Others," The New Republic, Dec. 2, 1985, pp. 28-31.
}

milieu of Leninism. Contrary to Besançon's opinion, the psychology of Leninism is deeply embedded in the millennial Russian historical experience and unfailingly conjures up the specter of anarchy at the mere suggestion of any dimunition of centralized authority.

Last but by no means least, there is the matter of the "scientifictechnological revolution." It is difficult to agree with Hoffmann and Laird that the Soviet system is successfully mastering its imperatives. To be sure, the Soviet leaders would like to borrow selectively from advanced technology for their own special purposes, namely, finding better methods of planning, administration, and political control. In other words, the Kremlin would like nothing more than to modernize Leninism. But its aspirations in this regard seem doomed to disappointment. Despite the Orwellian nightmare of a technologized totalitarianism, the "third industrial revolution" may actually enhance the realm of freedom. Whichever way this may turn out, advanced technology, particularly the computer revolution and the concomitant information explosion, threatens to burst the constraints of Leninism. The Soviet leaders appear only too cognizant of this fact; the resultant quandary constitutes a significant factor contributing to the Soviet Union's growing technological lag vis-à-vis the West.

In the final analysis, the relationship between Leninism and legitimacy is what lies at the very heart of the dilemma of change in the Soviet Union. On the one hand, the changes that seem essential for the survival of the Soviet system in the long run remain improbable if crucial Leninist tenets are not abandoned. On the other hand, the discarding of the doctrinal founda- 


\section{Books}

tions of Leninism would obviously undermine the Soviet party-state's claim to legitimacy. Either way, the last stage of Leninism appears to be at hand. Its historical role on the
Soviet scene all but played out, Leninism may well be no longer around in the 21st century in any presently recognizable guise. Considering the human toll that has been exacted in its name during the course of the present century, Leninism's impending demise, whenever it occurs, should occasion no lament. 


\section{Vladimir Tismaneanu}

FERENC FEHÉR, AGNES

HELLER, and GYÖRGY MÁRKUS. Dictatorship over Needs. New York, St. Martin's Press, 1983.

FERENC FEHÉR and AGNES

HELLER. Hungary 1956 Revisited. The Message of a Revolution - A Quarter of a Century After. London, George Allen \& Unwin, 1983.

"MARXISM has been the greatest fantasy of our century."" Thus Leszek Kolakowski characterized the mythical ambivalence of historical materialism, its intrinsic utopian dimension and longing for a new foundation of reality. Unlike other theologies, Marxism was able to deter for many decades the emergence of a sense of critical questioning, and to nourish passionate, even fanatical, emotional attachments on the part of normal-

Vladimir Tismaneanu, who received his Ph.D. from the University of Bucharest, is Hooper Fellow in International Security Affairs at the Foreign Policy Research Institute (Philadelphia). His articles on revolutionary ideologies have appeared in Orbis, Praxis International, Survey, and Telos. He has completed a study on the Latin American radical left and is working on a book on the ideological crisis of Soviet-type regimes.
GEORGE KONRAD. Antipolitics. San Diego, New York, London, Harcourt Brace Jovanovich, 1984.

OSKAR GRUENWALD. The

Yugoslav Search for Man: Marxist

Humanism in Contemporary

Yugoslavia. South Hadley, MA,

Bergin \& Garvey, 1983.

ly skeptical Western intellectuals. From Georg Lukács to Lucien Goldmann, from Max Horkheimer to Jean-Paul Sartre and Maurice Merleau-Ponty, historical materialism functioned as a metaphysical source, a shield against the liberal temptation and an invitation to that mystical drama that Hegelians called "the advent of the realm of freedom." The promise of total subjective emancipation the generous Messianic dream, rooted in German idealism and French Jacobinism - represented the precondition for the conversion of Marxism into an intolerant pedagogy, a dogmatic attempt to transcend the limits of the human condition and to challenge the ethical prescriptions that had guaranteed the continuity of European intellectual and political history.

Although Marxism has never been a monolithic entity, exponents of its diverse "orthodox" and "heretic" directions have all shared a certain rebellious instinct, an unacknowledged irrational vocation. In this sense at least, Leninism was a legitimate offspring of the original doctrine, and Antonio Gramsci was perfectly right in attributing to Lenin St. Paul's role in the expansion and in. stitutionalization of an otherwise esoteric creed. Lenin and Trotsky were the initiators of a new practice of philosophy, and their com. mitment to the use of terror against the "enemies of the Revolution" was a prelude to Stalin's ultimate bastardization of historical materialism. In the words of Milovan Djilas:

the dominant streak in Lenin's character and political practice was a ruthless will to coerce, dic. tate, and subjugate. Stalin's terror and Stalin's tyranny are unmistakably foreshadowed by Leninism. ${ }^{2}$

Contemporary Marxism presents a bewildering proliferation of neo-Marxist, "critical," or even "post-critical" schools, many of them unequivocally opposed to authoritarian regimes of the Soviet type. Praxis - the process by

' Leszek Kolakowski, "Marxism-A Summing Up," Survey (London), Summer 1977-78, p. 165; and Sidney Hook, Marxism and Beyond, Totowa, NJ, Rowman and Littlefield, 1983, pp. 54-72 (an excellent assessment of Kolakowski's contribution to the demystification of Marxism).

2 George Urban, "A Conversation with Milovan Djilas," Encounter (London), December 1979, p. 11. 
which, according to HegelianMarxist dialectics, the subject and object of history are supposed to become one - has regained its abstract and speculative content. This is particularly true of the East European critical philosophy of resistance, an intellectual current that emerged as "humanist revisionism" in the wake of Nikita Khrushchev's secret de-Stalinization speech at the 20th Congress of the CPSU. ${ }^{3}$ Georg Lukács and Ernst Bloch were the towering figures who inspired the theoretical awakening of East-Central Europe's critical Marxist intelligentsia. For a generation of disenchanted social philosophers, there were new illusions, new metaphysical dreams, brought into being during the painstaking operation of restoring intellectual sovereignty. The early Marx was invoked as an ally against the positivist doctrinaire late Marx; the young Lukács, with his eschatological pathos, was rehabilitated, together with other exponents of the critical tradition (e.g., Karl Korsch, Henri Lefebvre, Walter Benjamin, and Theodor Adorno).

IN THIS SETTING, the Budapest School audaciously defied the hypocrisy of Hungary party chief János Kádár's "repressive tolerance" and inaugurated a farreaching démarche whose basic aim has been to demythologize the ideology of "really existing socialism" and to dispel illusions about its nature. In Dictatorship over Needs, leading members of the Budapest School-Ferenc Fehér, Agnes Heller, and György Márkus - bear witness to the possibility of developing an uninhibited outlook capable of breaking through the

${ }^{3}$ Viadimir Tismaneanu, "Critical Marxism and Eastern Europe," Praxis International (Oxford), October 1983, pp. 248-61. veil of Marxist "false consciousness." Nevertheless, these onetime "pupils" of Lukács continue to insist on the relevance of the Marxian paradigm for the comprehension of authoritarian-bureaucratic systems. They persevere in investing their emotional capital in the humanist potential of the Marxist dialectic, although they are perfectly well aware that Stalinist and neo-Stalinist appropriation of historical materialism cannot but frustrate and severely compromise their own endeavor. The politicalphilosophical discourse of their book remains rooted in a certain type of "existential" Marxism. In other words, the authors base themselves on a Fichtean revolt against "reality" and claim, in good Hegelian tradition, that they would attain some "truer" reality beyond the present, spurious one.

The members of the Budapest School reject any pose of neutrality and raise their voices on behalf of the beleaguered "unhappy consciousness." Early Marxian categories, such as subjectivity and alienation, are central to their political-philosophical discourse. Abiding by a Blochian rather than a Lukácsian tradition, this school rebukes what Hegel called "reconciliation with reality" (Versöhnung mit der Wirklichkeit) and is deeply suspicious of the propensity of the radical-utopian Left in the West to dismiss the long-term implications that the failure of Marxism in Eastern Europe has for the nature of revolutionary thought itself.

The authors seem caught between their awareness of the ethical impasse inherent in Marxism and an unwillingness (or powerlessness) to go beyond Marxism itself. They continue to practice a sui generis variety of Marxism, something that one could call "antitotalitarian Marxism," but which is nonetheless anchored in the same intellectual matrix they wish to overcome. They prove incapable of scrutinizing the immanent pathology of historical materialism, of questioning its humanist pretentions, of introducing the criterion of praxis into their assessment of its contemporary hypostases. Yet, genuine post-Marxist critical philosophy- of which the Budapest School is in some sense a harbinger-must elaborate theses directly refuting the frozen axioms of historical materialism. In an ironic twist, these disciples of Max Weber's once most promising disciple-Lukács-need to rediscover the tension between reason and unreason and embark on a thoroughgoing critique of political ratio itself.

NO MORALISTIC indictment of Soviet-type regimes will succeed in undermining the pyramid of privilege erected in the name of Marxism-Leninism. Although an ethical-axiological scrutiny is certainly an indispensable component of any critique, the latter must be expanded to a general sociological interpretation of the subjective and objective background of collectivist-authoritarian regimes. One cannot sublimely ignore or discard Hannah Arendt's and Raymond Aron's penetrating dissections of totalitarian Leviathans.

The Budapest School views "dictatorship over needs" as a consistent Stalinist sociopolitical system that is central to Eastern Europe's Soviet-type regimes. It begins with the assumption "that the subjection of the 'rebellious' and 'individualistic' private person to a 'superior wisdom' has to be started at the level of his need system" (p. 227-28). "Dictatorship over needs" is thus a key concept that grasps the inner logic of the East-Central European regimes- 
the persistence of latent Stalinism in them. It suggests the process of dissolution of the autonomous subject within the overwhelming framework of totalitarian controls. Furthermore, this concept indicates the disastrous politicization of the psyche, the cynical manipulation of the subjective field, the attempt to do away with the sphere of privacy as an ultimate sanctuary of the ego.

Despite certain "liberalizing" measures, the totalitarian order remains basically unchanged, characterized by oppression in actu and in potentia, exercised in varying degrees according to the prevailing interests of the bureaucratic elite. On this issue, there is no significant difference between the Hungarian philosophers, who state that "East Europeans still live under Stalin's shadow" (p. xi), and Kolakowski, for whom

the so-called de-Stalinization, forced upon Communist states by various economic and political necessities, has not suspended the totalitarian principle. In Communist countries at the moment we are not dealing with "liberalized" or "democratized" variants of communism but essentially with an ailing Stalinism. ${ }^{4}$

In evaluating Eastern Europe's Soviet-type regimes, the Hungarians see no principle of moderation, no democratic rationality, underlying the functioning of the social organization. On the contrary, the recourse to violence is always possible, should the nomenklatura (the self-perpetuating political elite) feel its hegemony

"Leszek Kolakowski, "The Euro-Communist Schism," Encounter, August 1977, p. 14. See also idem, "A

General Theory of Sovietism," Encounter, May 1983, as well as his masterful Ma/n Currents of Marxism, Volume 3: The Breakdown, Oxford, Clarendon Press, 1978. jeopardized. One is tempted to make use here of the concept of "structural violence," the basic political strategy developed by a frightened "elite" whose incorrigible debility originates in the neversolved complex of legitimacy issues. For communist bureaucracies there is no basis of legitimacy other than sheer power, no authentic meritocratic competition, no reasonable hierarchy of values. This is particularly conspicuous in the case of self-contained hyperpersonalized-one might say "pharaonic" - regimes, such as the late Enver Hoxha's in Albania, Kim II-song's in North Korea, and Nicolae Ceauşescu's in Romania.

Yet the communist regimes are not actually as "solid" and immobile as they appear to be. The example of the Hungarian authors reviewed here refutes the image of these regimes' total manipulation of and control over their societies. Kádár's ideological watchdogs had to put up with these intellectual troublemakers for many years before hitting upon the optimal bureaucratic solution of banishment. (The emergence of Solidarity in Poland is, of course, another powerful argument against those who grant these systems an aura of immunity and infallibility.)

There is a negative principle working at the core of these regimes, despite the apparently smooth functioning of their repressive institutions. The logic of domination cannot ultimately prevail over the counter-logic of emancipation. The problem is whether a culture of resistance should include Marxism among its main components or should jettison it as a key feature of the execrated autocracy that is being resisted. To be sure, Marxism, as a Weltanschauung, cannot be reduced to the verbal ritual practiced by the servants of the "dictatorship over needs." But this political metaphysics cannot escape responsibility for the ruin of so many altruistic promises and the triumph of the worst species of tyrants in this century.

To go beyond myth and utopia, it is essential to discard the obsolete tenets and archaic symbols of Marxism, to transcend the "previous philosophical consciousness." Yet, the Budapest School is loath to commit intellectual parricide and remains sentimentally attached to the cultural-political horizon of historical materialism. These philosophers are obviously oriented toward a desirable, but according to them nonexistent, order of democracy and social justice. (Once again the real alternatives seem subordinated to ultimate metaphysical archetypes.) And if, as they argue, "the world needs more, not less, socialism than it has today" (p. xiii), one should perhaps question Marx's ghost regarding the tragic fate of political idealism and historical romanticism when converted into revolutionary praxis.

Unlike the historical school of Isaac Deutscher, the Hungarian critical Marxists refuse to subscribe to the Stalinist theory of "objective necessity." It is thus all the more urgent that they unify the theory of "dictatorship over needs" with a comprehensive interpretation of Marxism as an instrument of intellectual and political subjugation.

A particularly interesting chapter in Dictatorship over Needs focuses on relations between East European societies and the Western Left. The Hungarian authors, despite their disaffection with Soviet-type societies, seem still convinced that a dialogue is possible with certain West European communist parties. It is for these writers a matter of intellectual 
honor to persuade Western Marxists that "dictatorship over needs" is actually the opposite of any kind of humanist philosophy, including historical materialism. They therefore attempt to offer "an elementary model of the functioning of the Soviet social systems" (p. 40). Those systems, artificial as they were at the outset, invented their own mechanisms of "internalization" and succeeded in becoming a reference point, a "second nature" for various strata of the population. The main achievement of the system would be, eventually, to cauterize any sense of historical transcendence, to preclude the genesis of independent nuclei of thought and action - i.e., to effect a complete intellectual G/eichschaltung. Totalitarian systems aim to destroy the notion of individual autonomy. These authors correctly excoriate the immoral escapism of the Western Left in its attempt surreptitiously to dissociate the "innocent" theory from the abominable praxis, and they remind the reader that

these societies, however tragic this may be, do belong to the international history of that social and intellectual movement that bears the name of socialism. (p. 43)

The authors take on the eternal question about the origins and dynamics of social conflicts in Eastern Europe. Students of East European societies will certainly benefit from the stimulating discussion of bureaucratic planning as a social process, as an operation touched off and controlled by the apparatus as a "single corporate entity" (p. 77). In this view, planning is a euphemism employed to conceal the despotic style of these economies, their command character.

The Hungarian philosophers' expectation (inspired by the experi- ence of Solidarity in Poland) of the emergence of "self-created organs of a counter power" (p. 297) seems an abstract and overly optimistic appraisal of the window of tolerance currently granted by the system. Is this anything more than another utopian blueprint, rooted in sublimated despair and embarrassed feelings of defeat? As the authors themselves have to admit, such pluralistic forms of self-organization of various social groups can exist and survive only through violence, and, unfortunately, spontaneous oppositional violence in a police state is more often than not doomed to failure. Totalitarianism is totalitarianism precisely because it succeeds in combatting and eradicating areas of spontaneity and informal centers of communication. The matter is then how to outmaneuver bureaucratic manipulation and reinvent politics beyond the frontiers dictated by the system.

"Dictatorship over needs" represents a modernized version of Stalinist totalitarianism. Yet, although overt terrorism was replaced after Stalin's death with a more "moderate" dictatorial formula, the system has undergone no fundamental transformations that would warrant a different assessment of its "essence." Stalin's successors generally get by without using his atrocious methods, but they have preserved intact the entire infrastructure, perpetuating the risk or even the likelihood of a tragic return to terrorism. One shares the pessimistic conclusions of Albert Camus, for whom the pestilent rats, despite a temporary retreat, never totally surrender. 5

A principal function of communist bureaucracy is to exert dic-

${ }^{5}$ Rats being the metaphor for totalitarianism in Camus's novel the Plague. tatorship over ideas as well as over needs, to inculcate in its subjects its own image of the future, and to tame any form of resistance. The bureaucratic ethos involves a redoubtable esprit de corps, a solidarity developed through continued paternalistic behavior and jealously guarded monopoly of power. ${ }^{6}$

The dissolution of the civil society and the maintenance of an atomized political space, the sine qua non of the "dictatorship over needs," have provoked widespread moral paralysis and intellectual corruption in Soviet-type regimes. Mistrusted and despised even by many of its own promoters, Marxism-Leninism remains a guarantor, a means of ideological self-reproduction of the system. What is involved is a deliberate fabrication of self-images, ritualistically inculcated in the population. The ideologues fail to persuade the "propagandized" subjects but at least partially succumb to the fallacies they have themselves concocted. This is a strange interplay of illusion, cynicism, and self-deception, in which it is almost impossible to discern who really believes in and who only pretends to share the values of the system. Duplicity is the rule of the game.

The supreme irony is that the "ideologues" still hope to revive the mesmerizing function of the original doctrine and to that purpose obsessively reiterate the same hollow platitudes. A theory that was once able to inspire collective dreams and exalted sacrifices is reduced to a senile, unexciting, unappealing, and infinitely redundant succession of outworn stereotypes, a debased materialism

\footnotetext{
- See Ferenc Fehér, "Paternalism as a Mode of Legitimation in Soviet-type Societies," in T. H. Rigby and Ferenc Fehér, Eds., Political Legitimation in Communist States, New York, St. Martin's Press, 1982, pp. 64-81.
} 
altogether devoid of metaphysical sensitivity and humanist authenticity.

The "magic" principle of partiynost' (party-mindedness, or partisanship) replaces the obligation to search for truth, which, according to one of the few Gramscian theses actually accepted and quoted by Marxist-Leninist missionaries, is supposed to be "revolutionary." The Budapest philosophers describe this enthraliment:

The ways of the Party are enigmatic, indeed it is Kierkegaard's God that is embodied in it; no one can ever be in the right against it. (p. 191)

These authors expose the hidden rationale for the soporific, wooden jargon of official sermons and simulated faith: the exercise of domination by the bureaucrats. This topic merits further elaboration, since the language of Bolshevism has been the movement's most "effective" contribution to the desecration of humanist culture in the 20th century, and the source of its victory over competing totalitarian doctrines. This smothering rhetoric has imbued millions of books, booklets, and journals, and even a new species of human being, allergic to any sign of linguistic, let alone intellectual, spontaneity. The effects of this "semantic purge" were impressively described by Ludvik Vaculik:

The languages people speak today are seen as embodying the evolution of human knowledge. . . The men I talk to, by contrast, act and speak as if they had been excluded from this evolution, as if nothing had existed before them, as if we

'Ludvik Vaculik, "Thus Spake Schweik," The New York Review of Books, July 21, 1983. had been waiting for them to come to offer us everything that exists, and above all to keep it under surveillance. Modern physics talks of "antimatter"; here is "antithought."

Turned into a state religion, Marxism-Leninism became, as Cornelius Castoriadis and Claude Lefort demonstrated, the perfect language of domination. ${ }^{8}$

The Hungarian philosophers itlumine the resulting moral dereliction. In the building of the "new human being," the ethics of responsibility - the basis of Western moral philosophy - was abrogated and replaced by a new moral code, the ethics of heteronomy. The individual was absolved of personal implication in his deeds, and the party became the absolute arbiter of good and truth. George Konrád perceptively expressed the result in his historical-metaphysical novel The Loser:

It still didn't occur to me that my jokes could cost me my life. Communism for me was a metaphysical future, a second creation, the work of man replacing God, the axis of all known human values the thing we would accomplish together, correcting our errors as we went along, an open alternative to familiar oppression. I felt that if this experiment turned out to be a mistake, the human race would have lost its reason for being. What's more, the world of Communism for me was not merely living proof of its dialectics, but the pledge of my own survival, a unified force battling fascism which must, lest it be crushed, suspend its inherent benevolence

"Cornelius Castoriadis, "The Hungarian Source," Telos (St. Louis, MO), No. 29, 1979. pp. 4-6: Claude Lefort, Elements d'une critique de la bureaucratie (Elements for a Critique of Bureaucracy), Paris, Gallimard, 1979. from time to time, and, adhering to the rules of war, become as ruthless as its foes.

In the process the individual found himself victimized in the name of his ultimate freedom:

For the spectators the blood was tomato juice; for us the blood was our own. ${ }^{9}$

The tormenting question for the Budapest School-an issue that Kolakowski and Castoriadis unambiguously and trenchantly solved - is the relevance of the Marxian message for contemporary subjectivity, particularly in this age of "postmodernity," to use Alain Touraine's apt concept. They seem unable to confront the entire Jacobin tradition, including the mystique of the Enlightenment, that inspired the vicious experiment of "dictatorship over needs" that they so keenly criticize. These writers are further confronted with the contemporary obsolescence of the Left-Right paradigm and the obligation to reconsider fundamental topics in the light of the real and decisive conflict between democratic and totalitarian principles.

For those who have long been subjected to the "virtuous" pedagogy of socialism, a scholastic definition of the real substance of those regimes is actually irrelevant, particularly if the commentators retain their problematic commitment to radical socialism. As a basis for a critique of the "dictatorship over needs," some reference to existing, if imperfect, social-democratic experiments would be more effective than indulgence in hazy dialectical constructs and skeptical historical relativism.

- George Konrád, The Loser, New York, Harcourt Brace Jovanovich, 1982, pp. 138, 206. 
Even the Budapest philosophers discussed here seem to sense the inanity of their plaintive and solitary cri de coeur. One is reminded of Bloch's pathetic, and hardly consoling, words: "We have no confidence, we have only hope." 10

IT IS NATURAL that these philosophers are preoccupied with the Hungarian revolution of 1956 and seek to retrieve the spirit of that magnificent experience and to find in it political symbols that can nourish contemporary anti-totalitarian praxis. Hence Fehér and Heller's book Hungary 1956 Revisited, dedicated to the memory of the victims. This work is an invaluable introduction to one of the few world-historical events to occur in East-Central Europe in the aftermath of World War II and the Soviet occupation of that area. The Hungarian revolution marked the first time that Stalinist autocracy was challenged uncompromisingly, not only at the level of foreign policy, but at the fundamental one: the political organization of society. It engendered a new substantive principle, a new order of rationality that was the opposite of the mummified Stalinist

${ }^{10}$ See Jürgen Rühle, "The Philosopher of Hope: Ernst Bloch," in Leopold Labedz, Ed., Revisionism: Essays on the History of Marxist 1deas, New York, Praeger, 1962; and Ernst Bloch, Héritage de ce temps (Heritage of Our Time), Paris, Payot, 1978.

As for the Hungarian break with Marxism, Gyorgy Márkus wrote in a letter to this reviewer: "While I actually doubt the survival of a 'critical' Marxism as part of the counterculture in Eastern European circumstances (at least in the more quasi-liberal environments and for the time being - and essentially not for intellectual reasons), I further think that-despite its most real crisis - this heritage represents in its totality the intellectually deepest and most synthetic attempt to deal with the crisis-phenomena of modernity and as such both the theory and its crisis will stay with us for a long time." Personal correspondence by Márkus from The University of Sydney, Australia, March 29. 1983. See also Agnes Heller and Ferenc Fehér, Marxisme et démocratie. Au-delá du socialisme réel (Marxism and Democracy: Beyond Really Existing Socialism), Paris, Maspero, 1981. technology of power-namely, the emergence of the individual as the center of political discourse.

One of the most interesting chapters in this book consists of a rehabilitation of Imre Nagy, not only with regard to the scurrilous slanders proffered by the scribblers of the Kádár regime, but also with respect to those who, like Castoriadis, ignore the simple but fundamental fact that Nagy inaugurated a new type of radical practice. As Fehér and Heller so tellingly put it, Nagy "was one of the most remarkable specimens of a novel type in political activity: the post-Machiavellian politician." (p. 126)

This phenomenon is all the more remarkable because of the inexorable tendency of Stalinist parties to beget whole cohorts of superMachiavellians, from the Bolshevik Politburo to the inflexible champions of the Comintern (Georgi Dimitrov, Josip Broz Tito, Palmiro Togliatti, to name but a few).

Although I totally agree with Fehér and Heller that Nagy incarnated "the type of personality the anti-authoritarian revolution needed and will always need" (p. 128, emphasis in original), I still wonder how such a non-Stalinist activist (and he was a true militant) could have put up for more than 30 years with the Bolshevik "Inquisition." Was he aware, during the Moscow show-trials of that tortuous psychological mechanism Gramsci so aptly called "the hypocrisy of self-criticism"? During his Moscow exile, did he experience-like Lukács - the pseudomoral obligation to endorse, even if only by silence, the infamous sentences against the Old Bolsheviks?

No one can question the sincerity of Nagy's commitment to the cause of the 1956 revolution, but it is still debatable whether he actually anticipated many of the crucial consequences of his historical decision to join the masses instead of massacring them. It is certainly true, for example-as Fehér and Heller argue - that Nagy and the revolution he served personified certain libertarian values that were to be "adopted," or rather usurped, by the "Eurocommunist" parties. But he was by all means more than a "Eurocommunist" avant la lettre, more than an astute Realpolitiker, at least during the last days of the revolution and later on, during his deportation to Romania and the ignominious trial staged by Kádár and the Soviet KGB General Ivan Serov.

Nagy's last words suggest more than nausea and contempt for his former comrades, and the Hungarian writers are not mistaken in their conviction that these words uttered in intimate closeness to a posterity already awaiting him, expressed more than a communist querelle de famille:

"In this trial, in this tissue of hate and lies, I have to sacrifice my life for my ideas. I willingly sacrifice it. After what you have done to these ideas, my life has no value any longer. I am certain that history will condemn my murderers. One thing alone would repulse me: to be rehabilitated by those who will murder me." (p. 136)

Fehér and Heller are doubtless familiar with Jorge Semprun's writings about the Spanish communist movement and Santiago Carrillo's dubious career in it," and it is therefore surprising that they

" Jorge Semprun, The Autobiography of Federico Sanchez and the Communist Underground in Spain, trans. by Helen Lane, New York, Karz Publishers, 1979. For Semprun's more recent views concerning the destiny of Marxism, see his introduction to Lezsek Kolakowski, L'esprit révolutionnaire (The Revolutionary Mind), Paris, Denoël, 1985. 
would tend to associate Nagy's figure with a movement personified by the Spanish "Eurocommunist" professional manipulator. If it is true, as they claim, that Nagy rejected Khrushchevism as "a paternalistic consolidation of Stalin's decaying work" (p. 118), then he would certainly have resented the chameleonic posturing of such "Eurocommunist" luminaries as Carrillo, Jean Kanapa, or Giancarlo Pajetta. To accept the authors' portrayal of Nagy as "the first Eurocommunist" (ibid.) would diminish his historical stature and trivialize the meaning of his final divorce from the whole legacy of Leninism.

Nevertheless, benefiting from their friendship with Lukács and the opportunity to read some of the unpublished memoirs of Hungarian communist leaders, Fehér and Heller accomplish a praiseworthy task of historical and political restitution. In the process, they demolish the fellow-traveler-style literature concerning Kádár's "liberal" despotism, and put forward a new reading of Eastern Europe's communist drama in this century, with all its internecine struggles, Freudian complexes, and Macbethian plots. Witness the assassination in Kádár's jail of Geza Losonczy, whose daughter, according to George Konrád, is still imploring her father's murderers to tell her where his grave is. ${ }^{12}$ Losonczy, that irresistible intellectual who had been a hero of the anti-fascist underground and then, together with Kádár, a victim of Rakosist terror, ${ }^{13}$ was Imre

\footnotetext{
12 Reconfirmed in a conversation with George Konrád in New York on January 19, 1986.

13 On Geza Losonczy's biography, see The Truth about the Nagy Affair: Facts, Documents, Comments (with a Preface by Albert Camus), London, Secker \& Warburg, and New York, Praeger, published for the Congress for
} Cultural Freedom, 1959, pp. 122-23.
Nagy's most enthusiastic supporter. During his last year, he fell victim to paranoia and confessed to numerous imaginary crimes:

"I confess to being a spy on the payroll of Josip Broz Tito and Eisenhower; I admit that I incited a fascist counter-revolution against my nation and against the army of the glorious Soviet Union, the fatherland of all workers." (p. 165)

Losonczy, Nagy, Miklos Gimes, Istvan Bibo, Lukács, Tamas Aczel, Tibor Déry, Gyula Hay, Pal Maléter -these people and their comrades epitomized the regained honor of Hungarian culture, its irrepressible vitality. Of more global significance, they strove to establish a new body politic inspired by those values and principles to which Hannah Arendt alluded in her brilliant essay "The Revolutionary Tradition and Its Lost Treasure."14 The logic of heresy culminated in liberating apostasy. The dialectical celebration of wickedness, the unrestrained cult of sacrifice, and the self-flagellation of the intellect through the identification of truth with party, all those stifling rationalizations were finally exposed by these individuals. They succeeded thereby in breaking through the enthralling force of History and Class Con-

14 In Hannah Arendt, On Revolution, New York, Viking, 1963.

For the historical-political background of the Hungarian revolution, see the indispensable stuody by Ferenc A. Vali, Rift and Revolt in Hungary, Cambridge, Harvard University Press, 1961, as well as the important volume edited by Tamas Aczel, Ten Years After: The Hungarian Revolution in the Perspective of History, New York, Holt, Rinehart \& Winston, 1966, esp. the essays by Raymond Aron and Michael Polanyi.

15 Franz Borkenau insisted on Lukács's role in the crystallization of the "secret doctrine of wickedness" as an esoteric counterpart to the official theory which postulated identity between truth and the class consciousness of the proletariat. See Franz Borkenau, World Communism: A History of the Communist International, Ann Arbor, The University of Michigan sciousness, as young Lukacs had entitled his noted contribution on the "inevitable" victory of universal categories over frail particularity. ${ }^{15}$

DISSIDENT East-Central European intellectuals, with their outspoken discourse and refusal to acquiesce in the pragmatic imperatives of superpower politics, perceive Yalta as the starting point of a calamitous evolution, of a pattern of cynical treatment of nations and countries, and as the climax of short-sighted Realpolitik guided by ill-conceived Machiavellian assumptions. George Konrád's Antipolitics voices the growing malaise of those immediately subject to the long-term effects of the "Yalta logic," a revolt against the iniquitous international order imposed, in his view, by a collusion of contemporary empires.

It is one of the characteristics of Eastern Europe's post-World War II culture that literature and political sociology are inextricably linked, with literature being the main vehicle for conveying actual or potential dissenting views. As in prerevolutionary Russia, so in Soviet-type regimes in Eastern Europe, literature is charged with a subversive content, with that dimension of dissaffection with reality that is not permitted expression in political-philosophical

Press, 1971, pp. 172-73. On the same issue, see the superb chapter "The Revolutionary Commitment," in Melvin J. Lasky, Utopia and Revolution, Chicago, London, The University of Chicago Press, 1976. An important recent addition to the Lukács controversy is Hungarian philosopher and human rights activist Gaspar Miklos Tamas's "Lukács's Ontology: A Metacritical Letter," in Agnes Heller, Ed., Lukács Reappraised, New York, Columbia University Press, 1983, pp. 154-77. Tamas provides significant criticism of the Budapest School's tendency to idealize both Lukács's personality and his ethical stances.

For the impact of the young Lukács on contemporary critical Marxism, see the comprehensive study by Andrew Arato and Paul Breines, The Young Lukács and the Origins of Western Marxism, New York, The Seabury Press, 1979. 
works. This is, of course, true only for certain areas of the literary field, where censorship has somewhat subsided; it does not apply to pseudo-artistic celebrations of the communist status quo. This commitment of literature to fundamental human values was best expressed by Jaroslav Seifert, the Czech Nobel Prize-winning poet, when he declared in 1956:

If an ordinary person is silent about the truth, it may be a tactical maneuver. If a writer is silent, he is lying. ${ }^{16}$

In the 1970's, Konrád coauthored (with Ivan Szelenyi) a highly polemical interpretation of the status of the intelligentsia in the societies of "really existing socialism." 17 In certain points, that study anticipated many of the audacious hypotheses more recently advanced by the Hungarian author in his unorthodox introduction to Antipolitics, including the "emancipatory" mission assigned to a transnational intellectual elite. For Konrad, it is the calling of the freischwebende Intelligenz, as Karl Mannheim designated the freefloating stratum of uncommitted intellectuals, ${ }^{18}$ to suggest the guidelines for an alternative to the present political boundaries in Europe.

Unlike the East German Rudolf Bahro, Konrád nourishes no illusions with respect to the nature of the system functioning in EastCentral Europe. Far from considering it the result of a "revolution

18 See Michael Kaufman, "Czech Government Eulogizes Maverick Poet," The New York Times, Jan. 22, 1986.

"George Konrád and Ivan Szelenyi, The Intellectuals on the Road to Class Power, New York, Harcourt, Brace Jovanovich, 1979 .

18 Mannheim elaborated the theory of the epistemological privilege of the intelligentsia in his book Ideology and Utopia: An Introduction to the Sociology of Knowledge, New York, Harcourt, 1947. betrayed," he, like the Budapest School, seems to view the prevailing system as an autonomous social formation, intrinsically hostile to a free development of the human personality. Yet he suggests that "the nations of Eastern Europe have chosen a road that leads toward gradual and peaceful recovery of independence" (p. 26). Although Konrád concedes that "what Realpolitik seems to be telling us, from both East and West, is that we can loosen our bonds only to the extent that the Soviet Union can accept some gentle relaxation without suffering injury to its prestige" (p. 27), his hypothesis of marginal autonomy contains a good deal of wishful thinking. He overlooks possible Soviet reactions to any of the practical initiatives he is calling for, particularly the suggestion of a neutral Eastern Europe, which runs diametrically counter to Leninist-Stalinist expansionist logic. It is, of course, little wonder that utopian proposals appeal to East European intellectuals, who desire to escape the tragic quandary of having to choose between the Scylla of resigned compliance with the Prince - i.e., more or less honorable capitulation-and the Charybdis of quixotic rebellion.

However noble Konrád's aspiration for the creation of an autonomous and neutral Europe, his proposal smacks of the suicidal self-delusive conciliatory tendencies found in the West, that state of voluntary blindness Norman Podhoretz described as "the spirit of appeasement." 19 Like the pacifists and isolationists in the West, Konrád seeks to escape from neo-cold war rhetoric and

10 See Norman Podhoretz, "Appeasement by Any Other Name," Commentary (New York), July 1983; also Walter Laqueur, "The Psychology of Appeasement," ibid. October 1978. find new paths toward dialogue and mutual comprehension. Specifically, he calls for the abrogation of the Yalta agreements and the withdrawal of all foreign military force, Soviet and American, from Europe. "The key to peace," he argues, "is not disarmament but the mutual withdrawal of military forces" (p. 30). However, it is highly doubtful that any such Soviet "withdrawal," unlikely in any event, would automatically result in the kind of East-Central European neutrality that the Hungarian writer is aiming at. On the contrary, the most probable consequence of such an occurrence would be a mood of perpetual anxiety on the part of the Soviet leaders, manifested in strengthened censorship and ruthless suppression of dissent. There are no Soviet military forces in Romania or Yugoslavia, but the "dictatorship over needs" keeps going there. As Irving Kristol correctly emphasized,

it is a fact, not to be forgotten, that the Soviet Union has never reconciled itself to the dissolution of a Communist regime, anywhere, anytime. ${ }^{20}$

I would further argue with Konrád's self-styled East European Gaullism, evident in the suggestion that Europe become "an independent agent in the debate between America and the Soviet Union" ( $p$. 33). Europe cannot be a neutral partner to superpower dialogue; Western Europe, in particular, remains a natural ally of the United States in the struggle for the preservation of those very values that are imperiled by Soviet expansionism.

zo Irving Kristol, "Let Europe Be Europe," The New York Times Book Review, June 10, 1984, p. 15. The same point was poignantly made by Cornelius Castoriadis in "Defending the West," Partisan Review (Boston), No. 3, 1984, pp. 375-79. 
Getting rid of Yalta amounts to eliminating the causes of the cold war, and Konrád cannot be so gullible as to think, together with the American revisionist school, that the United States "provoked" the "peace-loving" Soviets into this confrontation. American forces in Western Europe maintain a status quo directly and consistently menaced by the Soviet Union, and it is naive to expect Soviet leaders to permit a peaceful transformation of East-Central Europe into a pluralist, politically neutral region.

Konrád knows too well that communists-committed to the principle of totalitarian conditioning and domination-cannot accept democracy. Even that most intelligent of Western Marxists, Antonio Gramsci, was committed to the same ideal and praxis-the seizure and preservation of power, even if he talked of hegemony rather than monopoly with regard to politicalcultural power. The Soviets are in Eastern Europe not for reasons of security, but primarily because they have to safeguard a myth, to prevent internal anarchy and the final collapse of the system. Prisoners of such insoluble dilemmas, swinging between utopia and despair, East European dissident intellectuals have acquired a sense of surreal political sociology unknown to their peers in the West, if one is to judge from the following quote from Konrád: "Our great dream: what would it be like if the Russian politburo were like the English queen?" (p.75).

Antipolitics is a manifesto for "the serpentine strategy of East European liberation" (p. 123). For Konrád, to foster "antipolitics" is to avoid millenarian temptations, to assuage visceral outbursts, and to encourage "a healthy pagan cynicism toward dedicated fanatics" (p. 172). Antipolitics would eventually amount to rediscovering the heuristic value of memory, enjoying the "dialogic rationality," and turning down the specious determinism of Soviet ideology. According to Konrád, a "second culture" would establish the authority of intellectual creativity over matters of spirit by annulling, through cathartic irony and a new sense of objectivity, the hypnotizing impact of ritualized clichés. In a word, the "power of the spirit" would undermine "the power of the state." For Konrád, antipolitics becomes another way of rejecting the absurdity of contemporary "ideological wars" and asserting the supremacy of permanent transpolitical values.

THE LAST of the volumes reviewed here, Oskar Gruenwald's The Yugoslav Search for Man, belongs as well to the philosophical literature of humanist Marxism. It is an honest and well-documented inquiry into the tribulations of Yugoslav "dialectical Marxism," an attempt to dissipate illusions concerning the Titoist social experiment. Together with Aleksa Djilas and Mihajlo Mihajlov, Gruenwald repre. sents a political orientation whose basic objective is to "democratize" the system, ${ }^{21}$ to uphold any effort aimed at weakening that system's repressive institutions.

Gruenwald characterizes the regime created by Tito and his party as an "enlightened despotism," whose faked tolerance vanishes as soon as it is confronted with a real political opposition. The imperatives of his struggle for survival

21 Pedro Ramet, "Yugoslavia and the Threat of Internal and External Discontents," Orbis (Philadelphia), Spring 1984, p. 120; and Pedro Ramet, Ed., Yugoslavia in the 1980's, Boulder, CO, Westview, 1985. Among the best-known works by Yugoslav humanist Marxists are Svetozar Stojanovič, Between fdeals and Reality, New York, Oxford University Press, 1973; and Minailo Markovič, From Affluence to Praxis, Ann Arbor. University of Michigan Press, 1974. with Soviet imperialism forced Tito to permit the emergence in Yugoslavia of avant-garde currents of intellectual resistance doomed to underground existence in other East European states. Yet, he did not welcome the critique of the metaphysical foundations of socialism that this openness engendered.

Such a critique was mounted by the philosophical school that coalesced around the journal Praxis. The Gruenwald book offers a fascinating exegesis of this school and suggests the reasons leading to the decision to put a brutal end to humanist Marxist free research in Yugoslavia. The Praxis group detected the aberrations of pseudo-socialist ethics, the intrinsic perversions of the system, and responded by founding a Marxist personalism. This philosophy was immediately denounced by ideological orthodoxy (in both Yugoslavia and other communist countries) as an assault against the very essence of "socialist systems."

Yugoslav humanist Marxist philosophers like Mihajlo Markovic, Svetozar Stojanovič, Gajo Petrovič, Rudi Supek, Ljubomir Tadič, and Predrag Vranicki dwelled upon the fundamental ethical issue of Marxist philosophy and praxis, the tension between means and ends, the relationship between revolutionary praxiology and teleology. They were aware that something was rotten in the Leninist-Stalinist, i.e., Bolshevik, approach to this topic, and attempted to develop an all-embracing critique of bureaucratic socialism.

These Yugoslav Marxists, subjected to harassment by the outraged communist apparatus, gradually realized the impossibility of avoiding a political collision with the exponents of the established power. Like the Budapest School, as well as Leszek Kolakowski and 


\begin{tabular}{|c|c|c|}
\hline $\begin{array}{l}\text { Karel Kosik, the Yugoslav critical } \\
\text { Marxists had to give up many radi- } \\
\text { cal-humanist illusions with regard } \\
\text { to the "reformability" of the system } \\
\text { from within. The required commit- } \\
\text { ment to the existing order - by an- } \\
\text { tiphrasis called "socialism" - was } \\
\text { replaced by an uninhibited exam- } \\
\text { ination of the factors that had } \\
\text { brought about the Stalinist } \\
\text { concentration-camp universe. } \\
\text { After a long and excruciatingly } \\
\text { painful journey, these critical } \\
\text { Marxists finally succeeded in } \\
\text { abandoning the "lyrical illusion," as } \\
\text { Malraux once called Marxist moral } \\
\text { idealism. They discovered the truth } \\
\text { of the observation by Albert Camus } \\
\text { that "none of the evils that totali- } \\
\text { tarianism claims to remedy ... is } \\
\text { worse than totalitarianism itself."22 }\end{array}$ & $\begin{array}{l}\text { the Praxis group took a long step } \\
\text { beyond the thrall of utopia and } \\
\text { revolution. Yet they suffered from } \\
\text { the same failing that plagued the } \\
\text { efforts of the Budapest School } \\
\text { - the ultimate inability to re- } \\
\text { nounce the central and contam- } \\
\text { inating commitment to Marxism. } \\
\text { East European critical Marxism, } \\
\text { in its most outspoken phase, has } \\
\text { debunked the sclerotic logic and }\end{array}$ & $\begin{array}{l}\text { apocryphal legitimation of the } \\
\text { existing regimes. Its moral-political } \\
\text { message, which seems now al- } \\
\text { most extinguished, functioned until } \\
\text { the late 1970's as a ferment of } \\
\text { radical opposition to the ruling } \\
\text { bureaucracies, contributing to the } \\
\text { genesis and development of the } \\
\text { dissident counterculture. This } \\
\text { process was accompanied, pri- } \\
\text { marily in Poland, Hungary, and } \\
\text { Yugoslavia, by a progressive dis- } \\
\text { enchantment with the merely hu- } \\
\text { manist (ethical) critique of the } \\
\text { communist regimes. This aware- } \\
\text { ness pointed to the necessity to } \\
\text { turn dissidence into opposition } \\
\text { and, as a logical inference, to } \\
\text { abandon Marxism as an inaccu- } \\
\text { rate and even misleading historical } \\
\text { perspective. }\end{array}$ \\
\hline
\end{tabular}




\section{Soviet Designs on Africa}

\section{Barry M. Schutz}

R. CRAIG NATION and MARK V. KAUPPI, Eds. The Soviet Impact in Africa. Lexington, MA, Lexington Press, 1984.

THOMAS H. HENRIKSEN, Ed. Communist Powers and SubSaharan Africa. Stanford, Hoover Institution Press, 1981.

PAUL B. HENZE. Russians and The Horn: Opportunism and the Long View. Marina del Rey, CA, European American Institute for Security Research, EAI Paper No. 5, 1983.

DAN C. HELDMAN. The USSR and Africa: Foreign Policy Under Khrushchev. New York, Praeger Publishers, 1981.

MILENE CHARLES. The Soviet Union and Africa: The History of the Involvement. Lanham, MD, University Press of America, 1980.

AT THE START of the last quarter of the 20th century, the Soviet Union jettisoned its policy of limited engagement in sub-Saharan Africa and the Horn and became a more active power in the region. Under the banner of countering imperialism, the Soviet Union intensified its efforts to establish close ties with African governments and radical political movements, undermine Western influence throughout the continent, furnish arms and training to revolu- tionary movements, and obtain military facilities wherever and whenever possible.

Why did Soviet leaders choose 1975 to intervene in African affairs? In addressing this question in The Soviet Impact in Africa, which he coedited with R. Craig Nation, Mark Kauppi identifies several congruent factors that influenced the Soviets' decision. In the region, in 1974-75, there occurred the collapse of the Portuguese em. pire and the overthrow of Ethiopian Emperor Haile Selassie by a radical military coup that required external support. On the global level, there was increasing Soviet awareness of a loss of resolve by US leaders after Vietnam and Watergate, as well as the concomitant implementation of Soviet bloc cooperative intervention in the Third World on the Soviets' behalf. This led Soviet leaders to believe that the global correlation of forces had shifted in their favor and that they therefore could project Soviet power well beyond their borders. While the novelty of this development receded somewhat in the time between the publication of Thomas Henriksen's edited collection, Communist Powers and SubSaharan Africa, in 1981 and the Nation and Kauppi volume in 1984, the Soviet Union maintains an active presence in Ethiopia and Angola, and, to a lessening extent, in Mozambique.
Following the main thrust of the Soviet allied interventions in Africa during 1975-79, the Soviets embarked upon an extended period of consolidation, a process that has produced something of a controversy among Western observers. Some have expressed fears concerning a further expansion of Soviet influence; others have predicted the reversal of Soviet/ communist fortunes in the region. ${ }^{1}$ Neither view, however, has been supported by events. There have been some Soviet gains, to be sure, but there have been notable setbacks as well. In his essay, "The Soviet Union and Zimbabwe: The Liberation Struggle and After" (in Nation and Kauppi), Keith Somerville cites Soviet miscalculation in backing the losing movement as the reason for the Soviets' failure to add black, revolutionary Zim-

\footnotetext{
1 For a discussion of the debate on recent Soviet fortunes in Africa, see Steven R. David, "Third World Interventions," Problems of Communism (Washington,
} DC), May-June 1984, pp. 65-71.

Barry M. Schutz is Professor of Third World/African Studies at the Defense Intelligence College (Washington, DC) and Adjunct Professor, National Security Studies Program, Georgetown University (Washington, DC). He has written widely on political change in Southern Africa and the Horn. 
babwe to its constellation of states in southern Africa after 1980. And in his "From Intervention to Consolidation: The Soviet Union and Southern Africa," also in Nation and Kauppi, Seth Singleton identifies the Soviets' failure to rebuild and develop Mozambique's warravaged economy as a major factor in the Soviets' declining influence in that country, despite the latter's continuing adherence to Marxist-Leninist political principles.

By contrast, Thomas Henriksen and Richard Bissell's sober assessments of the continuing Soviet presence in Africa, both in Henriksen's volume, point to the emergence of a qualitatively new Soviet threat based on the Soviets' enhanced ability to provide quick and massive military assistance over considerable distance, as well as on the great complementarity in political and military roles of the Soviet Union, Cuba, and the East European states. The Popular Movement for the Liberation of Angola (MPLA) still runs Angola with Soviet and Cuban arms and personnel, and Mengistu HaileMariam still rules Ethiopia-since 1984, with the support of a MarxistLeninist vanguard party (the Ethiopian Workers' Party). Thus, a curious stasis of Soviet influence and African resistance exists. While the Soviet/Cuban juggernaut of the late 1970's has been halted, the very presence of the two countries remains a dynamic factor in the politics of the region.

WHAT HAS BEEN the genesis of Soviet involvement in Africa, and does it have antecedents in Imperial Russia? Richard Bissell (in Henriksen) and Paul Henze (in Russians and the Horn) each elaborate pre-Bolshevik traditions of Russian "designs" on an Ethiopia that, like Russia, had an orthodox
Christian state religion and an imperial dynastic rulership. More generally, traditional tsarist interest in Africa, according to both Bissell and Henze, focused on the Russian desire to compete for influence with the established colo nial powers (Britain, France, Italy, the Ottomans) and the need to secure certain geopolitical objectives in the region. But the Russians were never able to match the success of the European colonial powers. This exclusion from the European colonial "club" in Africa in late 19th century, notes Bissell, seems to have whetted Soviet interest in Haile Selassie's Ethiopia, even to the extent that from 1953 to 1974 the Soviet Union was willing to provide aid to a feudal regime that was closely linked to the United States.

The persistence of this link, of course, was rooted in more than common tradition between the Soviet Union and Ethiopia. Russian geopolitical alignment with Ethiopia and the African Horn enabled Imperial Russia to gain access to the Indian Ocean, the Red Sea, and (later) the Suez Canal via the Mediterranean and Black Seas. Bissell distinguishes this "Russian" perception of the utility of involvement in Africa from the "communist" one which accentuates the spread of Marxist-Leninist ideology rather than the pursuit of geostrategic national interest (though the latter of course remains a Soviet concern). Dan Heldman's analysis of Soviet African policy during the Khrushchev era (1957-64), The USSR and Africa, also distinguishes these historical/geopolitical pressures from ideological motives of Soviet policy in Africa. Although Heldman generally concurs with Bissell's interpretation, he offers a more fully developed theoretical perspective of the pragmatic foundations of Soviet foreign policy-examined during Khrushchev's tenure-with emphasis on the legitimizing function of Marxist-Leninist ideology.

Ironically, geostrategic considerations, while generally mentioned only in passing in Soviet writings, are actually easier to grasp than are the more frequent and loudly proclaimed ideological justifications. Indeed, Soviet views toward revolution and the Third World have struggled to keep pace with a rapidly and pervasively changing global environment and a sometimes fluctuating line caused by political leadership changes. Milene Charles, in her The Soviet Union and Africa: The History of the Involvement, assiduously follows the circuitous path of CPSU policy toward, and the party's concomitant Africanist research concerning, sub-Saharan Africa since the Bolsheviks came to power. It is essentially a tale of missed opportunity, policy failure, and poor communication. From Lenin's advocacy of support for progressive national democratic (national bourgeois) forces in the colonized territories to Stalin's rigid "we-they" rejection of all but loyal Communists in such territories, Moscow failed to win true converts in Africa. Perhaps most poignant in this regard is Charles's portrait of George Padmore, the West Indian Communist who toiled to extend Moscow's line to the African colonies, only later to reject Moscow for Ghana's Kwame Nkrumah and Pan-Africanism in the 1950's and early 1960's.

Moscow's research on Africa, in the meantime, developed steadily. Soviet Africanist research in the 1920's anticipated the destructive potential of latent anti-colonialism among Third World elites. In the 1930's, D.A. Ol'derogge laid the foundation for the celebrated linguistic capability of Soviet Africanist research by establishing 
programs in Swahili, Hausa, Amharic, and Zulu. During the 1950's and the early 1960's, I. Potekhin headed research efforts into African ethnography, while in the late 1960 's and early 1970's, A. Solodovnikov developed and refined methods for conducting specialized economic analyses. Finally, by the late 1970's, Soviet Africanists even moved into the heretofore forbidden "bourgeois" fields of psychology and sociology.

In spite of this continuous line of research, the Soviets have a poor record on communicating effectively with African regimes receiving their support. Among Moscow's most notable failures were Ghana (1966), Mali (1968), the Sudan (1969), Nigeria (1972), and its recurring unpopularity in Sekou Toure's Guinea (with its most recent departure in 1978). It was not until 1975, when, ironically, Cuba took the initiative in developing the MPLA linkage with Moscow, that this poor performance was finally reversed. The "Cuban connection" not only ensured the Soviets' continuous influence and presence in Angola, it also provided Moscow with the essential surrogate military personnel to stymie the Somali drive into the Horn in 1977.

It was only when policymakers incorporated findings of research with actual political experience, however, that Soviet research on Africa yielded some concrete results. It helped Soviet decisionmakers correct a persistent tendency of the 1950's and 1960's to back the leader or movement with whom they were ideologically most comfortable. This propensity had inclined them to support such lost causes as those led by Patrice Lumumba in the Congo (Zaire) conflict (1961-65) and by Oginga Odinga in Kenya in the late 1960's. Thus, in 1969, having learned the hard way, the Soviets threw mili- tary support to the winning Federal forces in Nigeria (against secessionist Biafra) and sided with Siad Barre, who had just come to power via a military coup in Somalia.

But the Soviets were to learn yet another valuable lesson in Zimbabwe in the late 1970's. Moscow's propensity to play zero-sum games with competing movements smugly adhering to Joshua Nkomo and his Zimbabwe African People's Union (ZAPU) at the expense of Robert Mugabe and his Zimbabwe African National Union (ZANU) ultimately proved detrimental to Soviet interests there. As a result, Moscow now seems intent on avoiding the same mistake in South Africa by carefully touching all bases, keeping in contact with the weaker Pan-African Congress and the compromising Zulu leader, Gatsha Buthelezi, while directing fundamental support to the more popular, radical, and established African National Congress (ANC). Taking note of this recent Soviet proclivity, Bissell urges readers to understand that "the lessons the Russians have learned in their African experiences to date are likely to condition their intentions in the 1980's" (p. 1).

HOW MIGHT such lessons influence Soviet use of other Bloc states to help achieve specific goals in the region? Is there in fact a confluence of interests among members of the Bloc, or have some actions of certain Bloc members actually worked at crosspurposes with Soviet interests? The East European states' involvement in southern Africa is of course partially political for the Soviet Bloc. But it also holds considerable economic self-interest in the acquisition of many of the same mineral resources that the West requires. For this reason, argues Christopher Coker in his challenging essay "The Soviet Union and Eastern Europe: Patterns of Competition and Collaboration in Southern Africa" (in Nation and Kauppi), these states - in particular, Romania, Hungary, and Czechoslovakia - are not likely to support or encourage policies that would cut off the Cape Route for the West, since they too might suffer should such policies backfire. In fact, the Bloc states depend as much as Western states on the shipping route around the Cape for importing their own supplies, most notably to bring Middle East oil to East European ports in Soviet tankers. Of course, such dependency on open sea lanes generates considerable concern among Bloc states over what they perceive as increasing Western entrenchment in southern Africa. Thus, an antiSoviet (though pro-East European) Zimbabwe, an increasingly Western-leaning Mozambique, and a formidable anticommunist insurgency in Angola tend to heighten Bloc states' fears of restricted access to valuable resources in the region.

Coker also sees the East European states hedging their commitments in Angola and Mozambique, since the successful implementation of Soviet-style five-year plans in the two Lusophone states might actually stabilize their economies and engender steadier and more efficient Western investment. The potential impact of such investment increases in significance with the Bloc's 1984 rejection of Angola's, Mozambique's, and Ethiopia's bid for membership in the Council of Economic Mutual Assistance (CEMA), ${ }^{2}$ an action that surely casts a pall on long-term

\footnotetext{
2 See Coker, p. 67. Fortunately for these three AfroMarxist regimes, the European Economic Community and the Lome Conference have accepted them as recipients of developmental assistance.
} 
prospects for economic cooperation between the CEMA states and the Afro-Marxist regimes. Combined with inefficient Bloc economic management in Africa, exclusion from CEMA weakens "socialist orientation," especially in Angola and Mozambique. The latter's continuing drift to the West since 1982 may be a harbinger of Angola's subsequent fate.

Much has been written about the critical Cuban role in the Soviet intervention in Africa. The Cuban commitment to buttress the MPLA in Angola in 1975 has perhaps been the most important development in African politics since Ghana's independence in 1957. Cuba's entry into Angola with massive Soviet backing altered some basic conceptions regarding Soviet capability throughout the Third World, let alone that inherent to Africa. Cuba's military commitment, its effective coordination as a vehicle for Soviet African ambitions, and its remarkable ability to sustain its commitments have helped to further polarize politics in southern Africa by intensifying the arms buildup in South Africa and ultimately by driving Washington closer to Pretoria. As George Volsky argues in his perceptive though thinly documented essay, "Cuba" (in Henriksen), Cuba's operations in Africa show how a single leader of a small country working as a surrogate for one of the superpowers can decisively alter trends in the international system.

However, Cuba's entry into Africa has not been an unmixed blessing for the small Caribbean power. While most African states understand and accept Cuba's involvement in Angola, they do not necessarily view Havana's involvement in the Horn in the same light. Cuba's Angolan operation appears somewhat heroic because (a) it is perceived to have preceded and stimulated Soviet assistance; and (b) it was directed against the South African attack on Angola. Cuba's involvement in the Horn, on the other hand, is objectionable in African eyes because it is seen as tactical, that is, as subordinate to Soviet strategic aims in the region; and as inconsistent with Cuba's professed policy of nonalignment, an inconsistency that surfaces primarily in Cuba's abdication of material support for the Eritrean struggle.

But Cuba is not the only communist country whose activities have advanced Soviet interests in Africa. Yugoslavia in particular, notes Henriksen, has abetted the "spread of communism, if not the influence of the Soviet Union" ( $p$. 118). Henriksen makes a good case, but he infers more negative consequences for the West than seems warranted. (Indeed, it can be argued that Yugoslavia's modest support for ZANU in its struggle to achieve power in Zimbabwe has actually provided Robert Mugabe with an anti-Soviet Marxist-Leninist model for development.)

Romania, too, seems to have enhanced Soviet standing in southern Africa. Bucharest's interest in the National Union for the Total Independence of Angola (UNITAonce aligned with the MPLA but now its main opponent) before the joint Cuban-Soviet intervention in Angola in late September-early October $1975^{3}$ may yet facilitate a continuing East Bloc role there should the MPLA and UNITA ever form a coalition government. ${ }^{4}$

\footnotetext{
${ }^{3}$ For example, in April 1975, UNITA leader Jonas Savimbi was received in Bucharest by Romanian party leader Nicolae Ceaușescu. See, e.g., John A. Marcum, The Angolan Revolution: Exile Politics and Guerrilla Warfare (1962-1976), Cambridge, MIT Press, 1978, pp. 265-66.

4 It is interesting to note that the Reagan
} administration recently announced that it would seek a
Ironically, the activities of EastWest "bridge" states such as Yugoslavia, Romania, and even North Korea help retain a Western presence in the region as much if not more than they maintain and extend Soviet influence. This is so because the absence of direct Soviet involvement enables the newly independent African states to forge positions of nonalignment without sacrificing their revolutionary credentials. The existence of active Marxist model states with no particular subservience to Soviet aims has already proven to be a powerful force in Zimbabwe, Mozambique, and Angola and may exercise an even greater influence on a South Africa ruled by blacks, should this ever occur.

HOW DOES CHINA fit into all this? As is well known, in the mid1960's, the People's Republic of China (PRC) competed aggressively with the Soviet Union in Africa, offering emerging African states an especially vital alternative revolutionary model of development. A decade later, Chinese activism in support of the FNLA (National Front for the Liberation of Angola) and UNITA in Angola posed a severe problem to both Moscow and Havana which, during the transitional period in 1974-75, backed the besieged MPLA in Luanda.

Both William Ratliff, in his essay on "The People's Republic of China" (in Henriksen), and Colin Legum, in his "The Soviet Union's Encounter with Africa" (in Nation and Kauppi), stress the significant impact China had on the Havana-

joint congressional resolution proclaiming moral support for Jonas Savimbi and UNITA. This statement was made in anticipation of Savimbi's late January-early February 1986 visit to Washington. The administration made it clear, however, that it opposes giving military or economic aid to UNITA. See Bernard Gwertzman,

"Reagan To Offer Angolan Rebels Moral Backing," The New York Times, Jan. 26, 1986. 
Moscow decision to intervene in Angola. ${ }^{5}$ In fact, Soviet competition with Beijing for primary influence throughout southern Africa was truly a zero-sum game. For example, the Soviet Union refused to supply needed arms to Mugabe and his ZANU movement unless ZANU renounced its Maoist inclinations. (Mugabe refused to bow to Soviet pressure, and he later paid the Soviets back for their intransigence by denying the USSR any role in independent Zimbabwe.) Furthermore, one can argue that Mozambique's star has fallen, in Soviet eyes at least, partially because of the Mozambique Liberation Front's (FRELIMO) enduring relationship with Beijing before and after independence.

But Soviet competition with the PRC is not nearly so intense at present. Seth Singleton's chapter in Nation and Kauppi indicates that Moscow may even see Beijing's support for liberation in southern Africa as a potential source of tension between the United States and China. This is so, he suggests, because traditionally the aim of Soviet policy during periods of retrenchment is "to divide China and the United States rather than attempt new gains at the expense of both" (p. 119).

INDIGENOUS REGIONAL conflict has also had a decisive impact on developments in the Horn, and, according to some scholars, in spite of superpower competition in the area. The conflicts between Ethiopia and Somalia and between Eritrea and Ethiopia would exist even without superpower, and especially Soviet, involvement, says Marina Ottaway in her "Super-

"See also Jiri Valenta, "The Soviet-Cuban Intervention in Angola," Studies in Comparative Communism (Los Angeles), Spring-Summer, 1978, pp. 14-15. power Competition and Regional Conflicts in the Horn of Africa," yet another excellent contribution in Nation and Kauppi. Superpower competition may have fueled the flames of conflict, she concedes, but the source of the hostility can be found elsewhere, most notably in the policies and proposals of European colonial powers before and after World War II. For example, Great Britain exacerbated regional conflict in the Horn by proposing toward the end of the war the creation of a Greater Somalia that would comprise British Somaliland, former Italian Somalia, the Northern Frontier District of Kenya, and the Ogaden and Haud, internationally recognized territories within Ethiopia. Britain also proposed that Eritrea be divided between the Sudan and Ethiopia rather than be annexed by the latter. These proposals infuriated Haile Selassie in Ethiopia, incited emerging African elites in Kenya, and whetted the appetite of the Somalis inhabiting these diverse regions. In addition, the apparent irredentist impact of colonial, fascist Italy's policies on Somali nationalism contributed greatly to existing Somali claims and the subsequent conflict.

Eritrean expectations for a distinct political and cultural status were fed by 10 years of federation status within Imperial Ethiopia (1952-1962). Haile Selassie's termination of this arrangement sparked the formation of the Eritrean Liberation Movement (ELM) in 1961, a nationalist coalition that soon fragmented into the leftwing Eritrean People's Liberation Front (EPLF) and the more moderate Eritrean Liberation Front (ELF). Whereas from its inception, the ELF attracted Arab support, the EPLF turned to the Soviet Union and eventually obtained support from the Soviet bloc. Such support was acceptable to EPLF members because these countries represented a revolutionary alternative to the US-backed Haile Selassie regime.

Not all analysts, however, accept this interpretation. Some writers, such as Paul Henze, argue that "Eritrea" never existed and was only "created" by Soviet and other outside support. The Soviets were able to orchestrate the emergence of Eritrea, according to Henze, because of a coincidence of events: the development of a specious Eritrean nationalism stimulated by the rush to African independence in the early 1960's, and the enjoinment of Soviet and Arab interests after the 1967 Arab. Israeli war when the Eritrean cause became the object of Arab interest. Marina Ottaway, among other specialists on the Horn, finds no evidence to support Henze's assertion. Furthermore, there seems little basis for Henze's claim in Russians and the Horn, devoid as it is of any footnotes or bibliographical references, that it is an improvement on the "remark. able paucity of informed and balanced books on developments in the Horn of Africa during the past ten years" (p. 2). ${ }^{6}$

No doubt exists about long. standing Soviet interest in the Horn or about Moscow's historical fascination with Ethiopia. But irony touches the Soviets' finally reaching the Horn through a military

\footnotetext{
- Information and balance, of course, are in the eye of the beholder. Informative books on the Horn during the period in question include, in my opinion, Tom Farer, War Clouds on the Horn of Africa: The Widening Storm, 2nd ed., Washington, DC, Carnegie Endowment for International Peace, 1979; Marina Ottaway, Soviet and American Influence in the Horn of Africa. New York, Praeger, 1982; Marina and David Ottaway, Ethiopia: Empire in Revolution, New York, Holmes and Meier, 1978: Fred Halliday and Maxine Molyneux, The Ethiopian Revolution, New York, Schocken, 1982; and Richard Sherman, Eritrea: The Unfinished Revolution, New York,
} Praeger, 1980. 
buildup that enabled Somalia to invade Ethiopia in pursuit of its goal of "greater" Somalia. Paradox enters the Horn with the Soviet military and political swing to Mengistu's emerging revolutionary regime in Ethiopia. After Fidel Castro's fruitless attempt in early 1977 to reconcile Mengistu and Siad Barre in a Pax Sovietica of the Horn (which was to include South Yemen as well), Moscow realized that it had been euchred by Siad Barre who, in late 1977, expelled his Soviet advisers and abrogated Somalia's treaty of friendship with the Soviet Union. (Perhaps even more ironic, the Soviets may have had some awareness of, if not influence on, Somalia's impending attack on Ethiopia. $)^{7}$

The Soviet Union gambled, and lost, on its commitment to Somalia, sacrificing its investment in the port of Berbera in the process. But it did manage to recoup much of its losses by establishing a firm relationship with the Mengistu regime in Ethiopia. Determined to avoid a repetition of their vanishing acts in Ghana (1966) and Egypt (1973), the Soviets are exercising every stratagem derived from their 30 years of trial-and-error operations in Africa. Moscow's insistence on a vanguard party in Addis Ababa strikes a Leninist chord that the Soviets somehow seem to have forgotten in most of their African adventures heretofore.

EVEN IF IT IS TRUE that the Soviets have been disinclined to get involved in regional conflicts in the Horn, as Ottaway suggests, there is little doubt that they have a

'At the very least, the Soviets surely played an important role in the buildup of the Somali military. For example, Henze notes that "without Soviet support, the Somalis could not have developed the military strength to threaten Ethiopia" (p. 32). favorable disposition toward local disputes in southern Africa. Singleton argues that, in essence, the Soviet Union shares a propensity toward regional polarization with its putative nemesis, white-ruled South Africa. To the extent that Moscow succeeds in associating the United States with Pretoria's apartheid policy in South Africa, it gains the support of blacks in South Africa as well as of the Front-Line States (Angola, Botswana, Mozambique, Tanzania, Zambia, and Zimbabwe), Nigeria, and many other Third World countries. Moscow knows that South Africa is more important to the United States than it is to the Soviet Union and that the United States is trapped between disapproval of South Africa's internal policies and Washington's satisfaction with economic/strategic benefits accruing from its association with Pretoria.

South Africa likewise benefits from a certain level of regional instability that keeps the Soviet and Cuban pots boiling in Angola and Mozambique. The de-Sovietization of Angola might induce Washington to put even greater pressure on Pretoria to redistribute power inside South Africa. In order to help avoid such a development, Pretoria continually searches for real and imagined ANC training or stag. ing bases throughout the region. Internally, the repression of moderate black oppositionists (such as Steve Biko, Desmond Tutu, and African trade union leaders, among others) polarizes black opposition to white rule by creating more hard-line enemies and leading to a Moscow-dependent African National Congress revolution. ary movement as the only alternative to Afrikaner rule. This development-in full swing in late 1985-places the Soviets in the dominant position as political orga- nizers and military suppliers of the black opposition which also just happens to confirm Pretoria's worst fears and provide the latter with the rationale for further repression.

Stalemate over independence for Namibia follows the same script. So long as SWAPO (South West African People's Organization) is not in power, it needs Moscow's military support and Angola's territorial protection. But once in power, SWAPO would likely prefer to emulate nonaligned Zimbabwe, adhering to a pragmatic economic policy while inhibiting the ANC from staging attacks from its territory. Singleton astutely observes that such an outcome would greatly satisfy Washington but neither Moscow nor Pretoria.

WHAT THEN IS Moscow's ultimate objective in Africa? According to many of the contributors to the books under review here, the answer is straightforward: political leverage throughout Africa. As Richard Remnek and Joachim Krause argue in their two essays on Soviet military policy in Nation and Kauppi, as Milene Charles infers from the history of the Soviet involvement with Africa, and as Heldman implies in his case study of Khrushchev's Africa policy, the Soviet Union seeks political advantage over the West through essentially military means. The often conflicting goals of other Bloc actors, the alternative revolutionary model of China, and the constraints imposed by specific African states in African regional contexts limit Soviet prospects for the achievement of this objective.

But the Soviets have plied their interest in Africa for a very long time and through undulating phases. They have suffered setbacks in Ghana, Egypt, Somalia, and the Sudan only to reemerge in 
Angola and Ethiopia, among others, with renewed determination and new tactics for survival. They will no doubt continue to pursue their interests in Africa, perhaps content in the ideological certainty that, over the long run, history is on their side. Maybe in future, Soviet leaders will pay greater attention to economic rather than military assistance, or enlist additional Third World countries (for example, Ethiopia, South Yemen, Nicaragua) to serve as military surrogates for pressing Soviet interests umes by Henriksen and by Nation and Kauppi contain perspectives essential for assessing the past Soviet role in Africa, and perhaps even for anticipating Soviet intentions and operations in the future. 
NOTE: Readers are welcome to comment on matters discussed in this journal. Letters should be addressed to The Editors, Problems of Communism, US Information Agency, 301 4th Street, SW, Washington, DC 20547, USA.

\section{PHILIPPINES}

TO THE EDITORS: In his correspondence in the July-August 1985 issue of Problems of Communism concerning David Rosenberg's earlier article "Communism in the Philippines" (Problems of Communism, September-October 1984), Leif Rosenberger raises a rather crucial point that needs further clarification.

Mr. Rosenberger states that in 1983 "Carlos Gaspar, an East German, was discovered to be the CPP's link in a complex international funding support system" (p. 85). "Carlos" Gaspar is Karl Gaspar. But, in fact, he is very much a Filipino, not an East German, and served as Executive Secretary of the Mindanao-Sulu Pastoral Secretariat. Recently released from detention, he continues to be active in the Church. Nowhere in the source cited by Rosenberger (an Apr. 27, 1983, AFP transmission from Hong Kong translated in Foreign Broadcast Information Service, Daily Report: Asia and Pacific, Apr. 28, 1983), is Gaspar called an East German, although his first name is given there as "Carlito." Mr. Gaspar's writings are available in How Long?, Quezon City, Claretians Publications, 1985.

The issue concerning outside funding of the CPP is an important one and deserves careful research.

RICHARD J. KESSLER Senior Associate Carnegie Endowment for International Peace Washington, DC

\section{CORRECTION}

The title of the novel of William Faulkner that John and Carol Garrard reported had been excerpted in the Soviet literary journal Inostrannaya literatura (see "Soviet Book Hunger," Problems of Communism, September-October 1985, p. 80 ) should have been The Sound and the Fury.

\section{SOVIETS AT SEA}

TO THE EDITORS: In my review of four novels about the Soviet professional and military classes ("Novel Views of the Soviet Cadres," Problems of Communism, July-August 1985), I erroneously cited the preface to The Hunt for Red October as a source for the story of the attempted defection of a Soviet naval vessel to the West (p. 74). Memory deceived me. There is no preface; the passage cited is from page 88 of the novel itself.

There is, however, public evidence of the incident involving the Soviet frigate Storozhevoy, which left the port of Riga on November 8,1975 , manned by a crew who, together with the political officer, were attempting to seek asylum in Sweden. The vessel was intercepted by Soviet fighter aircraft and surface vessels and returned to Soviet custody. The best reference seems to be an article by Lt. Gregory Young, USN in the February 1985 issue of Sea Power, published by the US Navy. This article is summarized in The New York Times of February 10, 1985; Facts on File of April 5, 1985, also carries the item. According to Facts on File for June 12, 1976, the Stockholm newspaper Expressen on May 4, 1976, re ported the barratry by the Storozhevoy's crew.

DONALD F.B. JAMESON McLean, VA 


\section{SUBSCRIPTION ORDER FORM}

Mail with payment or credit information to:

Superintendent of Documents US Government Printing Office

Washington, DC 20402 (USA)

\section{BACK ISSUE ORDER FORM}

Mail with payment or credit information to:

Superintendent of Documents US Government Printing Office Washington, DC 20402 (USA) 


\section{ORDER FORM}

Please enter my subscription to PROBLEMS OF COMMUNISM (PROC) for one year (six issues) @ $\$ 16.00$ domestic or $\$ 20.00$ foreign.

Number of subscriptions

Enclosed is $\$$ $\square$ check,

$\square$ money order, or charge to my

Deposit Account No.

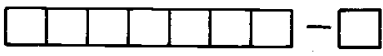

Order No.

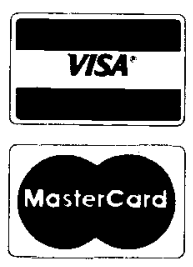

Credit Card Orders Only

Total charges $\$$ Fill in the boxes below.

Credit

Card No.

Expiration Date

Month/Year

Name-First, Last

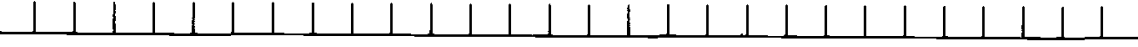

Street address

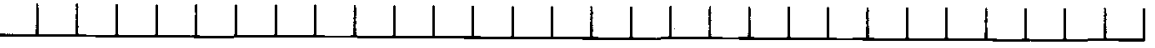

Company name or additional address line

Please make checks payable to

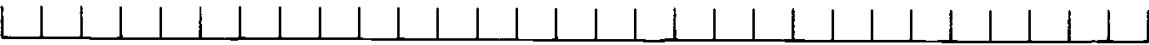

City State ZIPCode

Superintendent of Documents USGPO

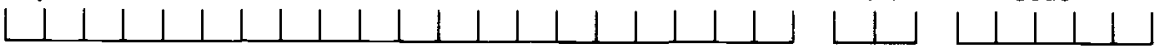

(or Country)

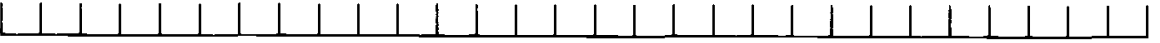

Mail To:

Superintendent of Documents

U.S. Government Printing Office

PLEASE PRINT OR TYPE

Washington, D C 20402

\section{ORDER FORM}

Please send the following back issue(s) of PROBLEMS OF COMMUNISM (PROC) @ $\$ 2.75$ domestic or $\$ 3.44$ foreign.

Date(s) of issue(s)

Enclosed is $\$ \ldots$

$\square$ money order, or charge to my

Deposit Account No.

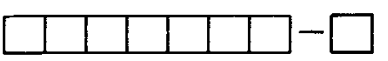

Order No

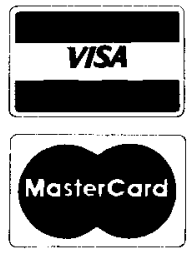

Credit Card Orders Only

Total charges \$

Credit

Card No.

Expiration Date

Month/Year

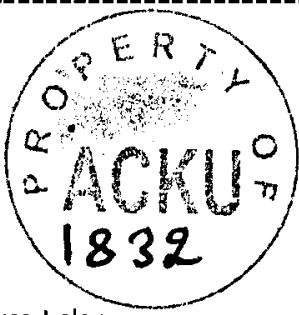

Fill in the boxes below.

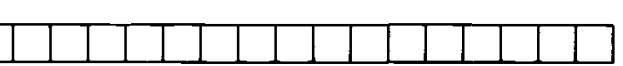

Name-First, Last

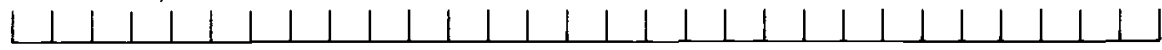

Street address

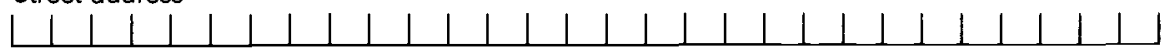

Company name or additional address line

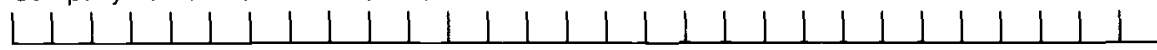

City

State ZIP Code

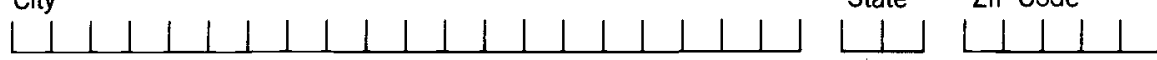

(or Country)

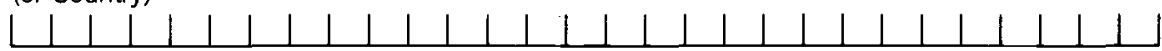

Please make checks payable to

Superintendent of Documents USGPO

Mail To:

Superintendent of Documents

U.S. Government Printing Office

Washington, D C 20402 


\section{Problems of Communism}

\section{SUBSCRIPTIONS}

ANNUAL SUBSCRIPTIONS or copies of recent (the last three) issues of Problems of Communism may be obtained by writing to the Superintendent of Documents, US Government Printing Office, Washington, DC 20402 (USA). Subscription blanks for one-year and single-issue requests are provided on the facing page. For further information, see the inside front cover.

CURRENT PRICES: Annual subscriptions, US mailing address, $\$ 16.00$ each; outside the US, $\$ 20.00$ each. Single copies, US mailing address, $\$ 2.75$ each; outside the US $\$ 3.44$ each. A 25 percent discount is allowed on orders for 100 or more subscriptions or single copies mailed to a single address.

ENCLOSE CHECK OR MONEY ORDER, payable to "Superintendent of Documents, USGPO," or if paying by VISA or Master Charge, please indicate credit card number in the space provided on the subscription blank.

Problems of Communism

\section{REPRINTS, MICROFILM, REPRODUCTION}

A variety of services, ranging from reprints, through microfilm and microcard editions, to reproduction of individual issues or articles are commercially available. Those firms which offer one or more such services and which have come to the Editors' attention are, in alphabetical order:

Bell \& Howell Micro Photo Div.

Old Mansfield Road

Wooster, $\mathrm{OH} 44691$

Inst. for Scientific Information

3501 Market St.

Philadelphia, PA 19104

Microforms International Mktg. Co.

Fairview Park

Elmsford, NY 10523
J. S. Canner \& Co. 49-65 Lansdowne Street Boston, MA 02215

\author{
Infordata International, Inc \\ 175 East Delaware Place \\ Chicago, IL 60611
}

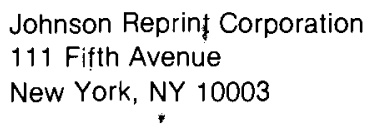

John T. Zubal, Inc. 2969 West 25th Street Cleveland, $\mathrm{OH} 44113$

Annual indices for Volumes IV-to-date appear in the November-December issue (No. 6) for each year. A combined index to the first three volumes is contained in Vol. III, No. 6 (November-December 1954). 